\title{
Special Report 5: International Energy Cooperation and Governance
}

\author{
Wei Jigang and Peter Webb
}

\section{Executive Summary}

Currently, the global energy landscape is undergoing major shifts in terms of demand, supply, technology, structure, market and investment. Countries have general requirements for improved air quality and reduced emissions and pollution. International energy cooperation and governance must adapt to these new changes; promote the transition to clean, low-carbon, efficient and secure global energy; and drive high-quality development of global energy.

\section{DRC Team Lead of Special Report 5:}

Wei Jigang from the Research Department of Industrial Economy, Development Research Center (DRC) of the State Council of China.

Shell Team Lead of Special Report 5 :

Peter Webb, Government Relations Advisor, Shell International B.V.

\section{Contributors:}

Rob Bailey, Daniel Quiggin, Felix Preston and Sian Bradley from the Department of Energy, Resources and Environment, the Royal Institute of International Affairs; Hong Tao from DRC; and Chen Jinxiao from the Chinese Academy of Social Sciences.

W. Jigang $(\bowtie)$

Research Department of Industrial Economy, Development Research Center (DRC) of the State Council of China, Beijing, China

P. Webb

Government Relations Advisor, Shell

International B.V., The Hague, the Netherlands

\subsection{Making Global Energy Governance Fit for the Future}

Energy security has traditionally focused on oil and gas supply security and price stability and created a set of international energy governance regimes. Today, three key trends are reshaping the nature and focus of international energy cooperation and governance. First, most governments and companies recognise that energy security must be delivered alongside rapid action to reduce greenhouse gas emissions. Second, there are increasing concerns over air pollution at the national level. Third, policy encouragement for lower carbon, cleaner options has helped spark technological advances and declining prices. International energy governance needs to adapt to new market realities and shifts in energy mix in order to remain relevant and effective.

However, the current global energy governance regime suffers from two principal deficiencies in its ability to facilitate a low-carbon, secure energy transition. First, the principal energy security regime of the International Energy Agency (IEA) does not include emerging economies, which account for a major, and growing, share of consumption. Second, even though the energy sector is responsible for around two-thirds of global greenhouse gas emissions, climate objectives have not been fully integrated into energy governance arrangements. 
Harmonisation of global energy and climate governance regimes could be achieved by a long-term agenda under the auspices of the G20, beginning with the alignment of international organisation mission statements. This requires steps to build the G20's leadership and oversight function by establishing a long-term series of G20 energy ministerial meetings and building an energy secretariat function.

\subsection{Investment Regimes for a Low-Carbon, Energy-Secure Transition}

Allocating investment during a swift energy transition, while maintaining oil and gas supply security and reliability of electricity networks, requires clear market signals and the incorporation of transition risks into the cost of capital. However, the global coverage and level of carbon pricing are insufficient, fuel subsidies distort investment decisions, and transition risks are poorly understood by capital markets.

As significant heavy industries embark on domestic carbon pricing, it is in all countries' interests to ensure a level international playing field through the widespread adoption of carbon pricing elsewhere. And it is in all countries' interests to ensure sufficient global investment in hydrocarbon exploration and development through the transition, in particular to avoid supply crunches.

International momentum to propagate carbon pricing and improve the incorporation of transition risks into financial decision-making is growing. G20 states collaborate with each other to support the development, adoption and implementation of the recommendations of the Financial Stability Board's Taskforce on Climate-related Financial Disclosures. G20 states continue to support the phase-out of fossil fuel subsidies and work through multiple channels to promote carbon pricing through lesson sharing, clarify regimes for linking markets under the United Nations Framework Convention on Climate Change, and explore the use of border adjustment measures to encourage wider adoption and reduce leakage.

\subsection{Security of Supply of Metals and Minerals for Future Energy Systems}

Concerns are growing about the security of supply of metals and minerals critical to the manufacture of technologies and infrastructure for future energy systems. Compared to markets for oil and gas or agricultural commodities, markets for metals and minerals have poor information and weak governance.

Secure supply of affordable raw materials will be crucial to the economic security of all countries.

Supply chain shortages and trade disputes could be avoided by countries working together to improve information, data and price transparency across the supply chain, while also supporting dialogue and developing win-win technology and investment packages with existing, new and emerging producers to encourage trade and prevent export controls.

Circular economy strategy could also help reduce the long-term import needs of these critical materials. There should be greater focus on research, development and demonstration (RD\&D) of enhanced recovery and recycling of metals and minerals from in-use stocks, enabling the greater use of secondary materials.

Reducing reliance on critical metals and minerals could be furthered by forming unconventional alliances with regional neighbours to support RD\&D of substitute technologies for those low-carbon energy technologies most dependent on critical metals and minerals.

\subsection{Electricity Reliability During the Shift from Molecules to Electrons}

Steep reductions in the cost of clean energy technology are accelerating the shift from molecules to electrons. The nature of energy security is therefore also changing, not least because an electricity-focused energy system requires real-time management for system reliability. Interconnection of national electricity grids can 
help balancing, reduce electricity costs and provide opportunities for trade.

\subsection{Strategic Path for International Energy Cooperation}

International cooperation is critical to achieving global energy objectives. The global challenge of enhancing energy security over the course of the next half century, while decarbonising the energy sector, will not be achieved through governments acting unilaterally in isolation from one another.

In Fig. 1, the proposed international cooperation options are shown on a matrix. The horizontal axis represents a spectrum from bilateralism to multilateralism, and the vertical axis represents a continuum from market-led approaches to more direct policy interventions.

As noted above, these proposals should be viewed as part of a broad package, since many could be delivered together, and implementing some depends on progress in others. However, what is obvious is that, while the options span a range of market- and policy-led approaches, few are based on a transactional approach. Instead, the proposals cluster among regionalism and multilateralism in the form of efforts to establish, strengthen and propagate common rules and norms.

Patience will be required, as the success of many of these proposals rests on wider political dynamics beyond the energy sector, not least China's relations with the USA and other countries. Moreover, realising the win-wins that are available will often require compromise. In addition, the Belt and Road Initiative can provide a platform for regional and plurilateral governance by establishing rules of the road; alternatively, it could provide an arena for country-by-country bilateral deals.

G20 plays a central role in many of the proposals. It provides a potential avenue through which China and partner countries can pursue reforms and has a track record of reforming international organisations and establishing new ones. Its membership has critical mass in key areas such as emissions, energy consumption and investment, and R\&D. And it has existing workstreams in relevant areas such as infrastructure, green finance, investment and fossil fuel subsidies.

As such, the G20 could evolve into the apex organisation for global energy governance. But this will not happen overnight, and considerable effort would be needed to build and sustain its capacity to do so.

\subsection{China Should Develop Future-Oriented Win-Win International Energy Cooperation and Shoulder Greater Responsibilities in Global Energy Governance}

As a large country with high levels of energy production, energy consumption and trade volumes, as well as increasing dependence on foreign energy, China's development has had significant and far-reaching impacts on the global energy landscape. Moreover, China is beginning to be a global leader in the deployment of energy technologies. As a major manufacturer and exporter of low-carbon technologies, China stands to benefit economically from rapid global decarbonisation; and as a country with high levels of exposure to climate risks, China also stands to benefit from accelerated global emissions reductions. Finally, as the world's largest energy consumer, China is exposed to market disruptions and it benefits from resilient international energy markets.

To establish a stable, effective and sustainable energy supply system, China must implement a more inclusive international energy cooperation strategy and promote win-win collaborations. Strategically, China should deepen international energy cooperation in five aspects: multi-level international energy cooperation partners, multi-channel international energy cooperation methods, diversified international energy cooperation forms, multi-area international energy cooperation content, and multi-task international energy cooperation processes. 


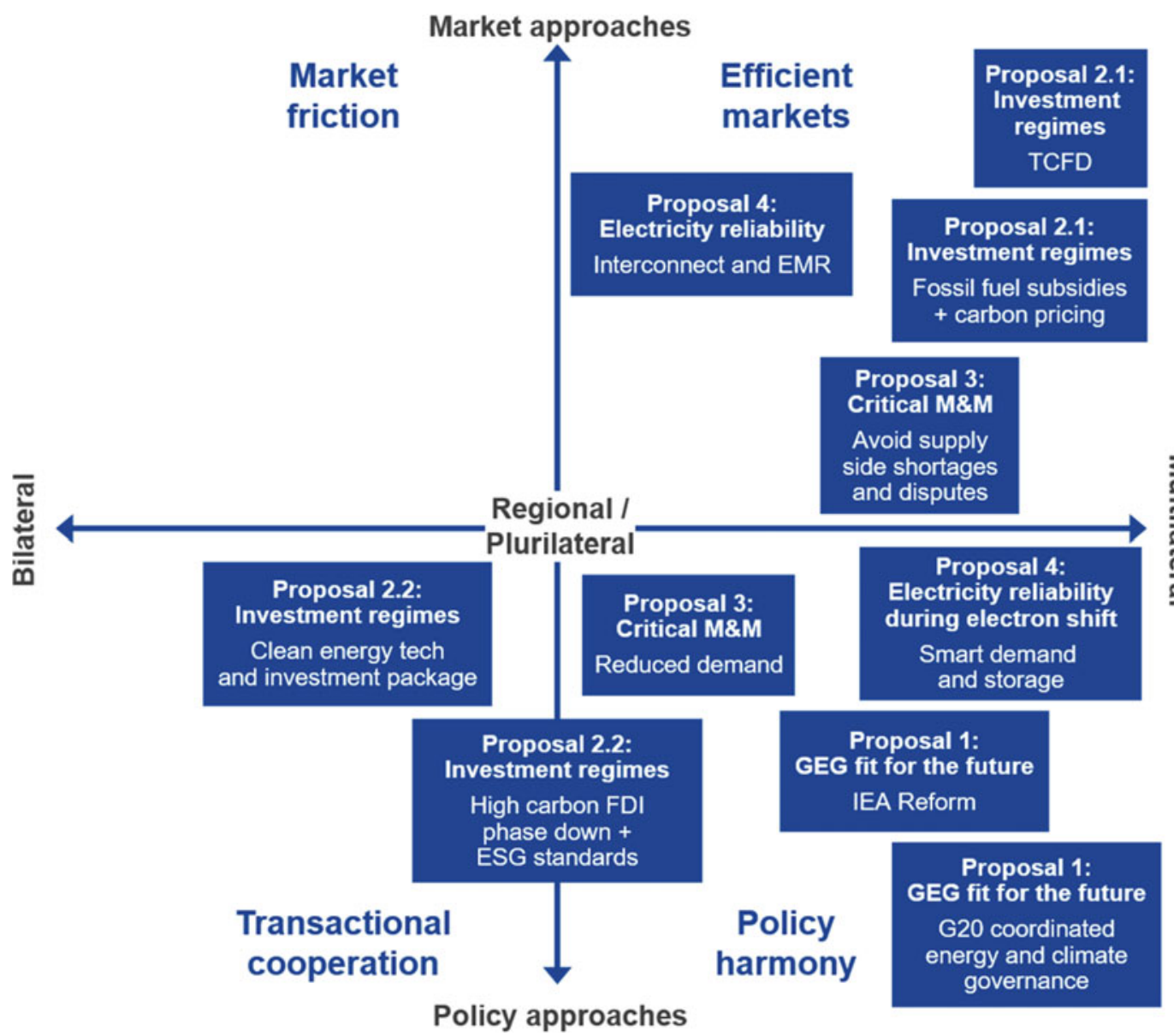

Fig. 1 Strategic path for international energy cooperation. Note TCFD = Taskforce on Climate-related Financial Disclosures; FDI = foreign direct investment;

Due to its leadership role among emerging economies, and its position as the world's largest energy consumer and greenhouse gas emitter, China is uniquely placed to drive global energy governance reforms.

China should undertake a major power's responsibilities in global energy governance. It should drive change of the international energy governance landscape dominated by developed economies to make the global energy governance regime more representative and better reflect the interests of developing and emerging economies. And it should propose building a shared future in global energy to deliver win-win results with the world. China has a responsibility to reduce
ESG = environmental, social and governance; $\mathrm{GEG}=$ global economic governance; IEA = International Energy Agency. Source IEA (2017); BP Energy Outlook 2018

emissions, promote the energy revolution and lead in the energy transition, and be open to the outside world.

First, China should participate deeply in the current cooperation between, and reform of, existing international energy governance institutions. Specifically, China should actively advocate or lead the amendment of international mechanisms and the establishment of new ones. It should integrate with the international energy market and participate in global energy governance in depth, thus becoming an active, responsible, constructive and reliable contributor.

In particular, China should: (i) have comprehensive strategies and a roadmap for its 
participation in global energy governance; it should assess the cost and benefits of participation and identify the methods and support systems needed for participation; (ii) meet the expectations of the international community, such as joining the IEA's emergency response mechanism and improving data quality; (iii) establish an internal conference and consultation mechanism for international energy issues and allow the authorised departments to attend international conferences to make China's voice heard in a more powerful way; (iv) collaborate with G20 emerging economies to promote IEA reform; and (v) identify the international energy conferences and activities to participate in and the department and officials who should take part.

Second, China should strengthen regional energy security and align it with socioeconomic development. Specifically, China should: (i) form a community of common interests and bolster energy security through regional and multilateral cooperation; (ii) collaborate with global or regional organisations to establish stable and cooperative relations between energy suppliers and users; (iii) participate in regional multilateral governance to promote regional energy security and the joint development of all parties' energy economies; (iv) better manage its different governance roles at regional and multilateral levels; (v) insist on mutually beneficial bilateral cooperation and enhanced multilateral cooperation; and (vi) improve energy security while hedging against the possible failure of IEA reform.

Third, China should strengthen its participation in global energy governance and its ability to: (i) set international energy agendas, especially those representing emerging and developing economies; (ii) expertly apply international energy rules, especially the laws and regulations governing international energy trade and financial investment; (iii) optimise domestic energy governance and undertake effective energy diplomacy to reform international energy cooperation and make it more inclusive of developing countries; (iv) have sufficient human resources with the right training for international energy governance; (v) enable its energy companies to participate in the international energy market; and (vi) build discussion platforms with the help of non-governmental and international organisations, and enhance research on, and capacity building for, participation in global energy governance.

\section{Introduction}

As energy systems around the world undergo major shifts, global energy governance ${ }^{1}$ (institutions, mechanisms and norms) and international energy cooperation must evolve to remain relevant. Given the high transaction costs associated with the creation or the reform of multilateral institutions, changes in the past have often been slow and piecemeal. Yet abrupt economic and energy security crises have, at times, led to more dramatic changes - most notably after the 1973 oil shock.

Most governments and companies recognise that energy security must be delivered alongside rapid action to reduce greenhouse gas emissions. Air quality is another driver of change, especially in developing and emerging economies. Meanwhile, policy encouragement for lower carbon, cleaner options has played a role in sparking technological advances and declining prices.

Achieving the Paris Agreement's goals of limiting global warming to well below $2^{\circ} \mathrm{C}$, while ensuring energy security through the transition, presents a major challenge to both national and collective energy policymaking. Without concerted domestic action and cooperation at unprecedented scales, the world is unlikely to see the tectonic shifts in technology deployment and capital allocation that are required.

The transformation of energy markets and investments is changing the terms of energy

\footnotetext{
${ }^{1}$ See page 3 of the Chatham House - DRC report, Navigating the New Normal: China and Global Resource Governance, for a comprehensive definition of global resource governance, including energy governance. Available at https://www.chathamhouse.org/sites/files/ chathamhouse/publications/research/2016-01-27-chinaglobal-resource-governance-preston-bailey-bradley-weizhao-final.pdf.
} 
choices. As transport and heating become increasingly electrified, the focus of policy is beginning to shift from the governance and security of molecules to that of electrons. The expansion of electricity networks, rapid deployment of electric vehicles and growth in storage capacity could become a self-reinforcing dynamic, creating new trade patterns and interdependencies.

It is in all countries' national interests to ensure energy security. Much has been made of China and the EU's growing dependence on oil imports, in contrast to North America's emerging age of energy independence, following the shale gas revolution. However, as the nature of energy choices shift, the emphasis of energy policy and international cooperation is expanding to include the governance of grids and cross-border trade in electricity, as well as the supply security of critical metals and minerals for the low-carbon economy, such as lithium, cobalt and nickel.

Governments also have broader strategic interests that are linked to energy governance and cooperation, from economic performance to quality of life, including clean air and water. These policy areas are inextricably linked to domestic energy choices - regardless of a country's level of dependence on overseas imports or its role as an energy exporter-and are facing increasing public scrutiny. Table 1 describes some of the key strategic interests of major economies and how they might be affected by a revised perspective on energy security and cooperation that encompasses energy transition.

Governments will need to use a combination of unilateral, bilateral and multilateral approaches to manage these challenges effectively. While effective engagement and joint leadership in a multilateral context require significant political capital in the short term, in the longer term such an approach can help mitigate the substantial transaction costs associated with managing multiple bilateral relationships. It can also help reinforce emerging international norms and provide a consistent structure for international cooperation.

With the exception of the Paris Agreement, progress in multilateral forums has been slow and complicated. Governments need to begin laying the foundations for multilateral approaches early and be willing to play the long game, while at the same time leveraging unilateral, bilateral and thematic approaches to expedite progress at the multilateral level and plug the gaps in the existing energy governance architecture. These approaches will need to be resilient and able to adapt to changing political and economic contexts, climate shocks and new information.

Pragmatic approaches will be needed-in many cases working within existing institutions and groupings, and in others working to reform them. The G20, for example, accounts for more than $80 \%$ of global GDP, global primary energy demand, and global emissions respectively, and has the collective capacity to drive change on various fronts including investment, infrastructure, access to energy and fossil fuel subsidies. The International Energy Agency (IEA), by contrast, is declining in relevance as hydrocarbon demand growth shifts away from its member OECD countries towards emerging markets, and as increasingly complex energy systems break down and make the distinction between producers and consumers less distinct.

\section{Box 1: Definitions of international cooperation and global energy governance}

While no official definition of global governance or international cooperation exists, here we define the two in the following terms. Global governance can be undertaken by a coalition of national governments, market actors, regulators or lawmakers, within a formal or informal multilateral organisation. Decisions within these organisations, structures and mechanisms influence hard rules such as national laws, regulations and standards, but also soft rules such as norms and cultural practices. Rules can arise from the bottom up, for instance Internet governance, as well as from the top down, in the case of the United Nations. 
Table 1 The key strategic interests of major economies and the potential impacts of a revised perspective on energy security and cooperation

\begin{tabular}{|c|c|c|c|c|c|}
\hline & $\begin{array}{l}\text { Trade } \\
\text { dependencies }\end{array}$ & $\begin{array}{l}\text { Access to critical } \\
\text { metals for } \\
\text { low-carbon energy }\end{array}$ & $\begin{array}{l}\text { Cross-border } \\
\text { electricity and } \\
\text { interconnections }\end{array}$ & $\begin{array}{l}\text { Leadership in clean } \\
\text { energy technologies }\end{array}$ & $\begin{array}{l}\text { Energy-a key } \\
\text { component of } \\
\text { international } \\
\text { cooperation }\end{array}$ \\
\hline China & $\begin{array}{l}\text { Oil security is a } \\
\text { top priority. } \\
\text { China is the } \\
\text { world's largest } \\
\text { net oil importer. } \\
\text { Concern over } \\
\text { instability in the } \\
\text { Middle East } \\
\text { (which supplies } \\
\text { 50\% of imports) } \\
\text { as well as } \\
\text { strategic maritime } \\
\text { choke points } \\
\text { (straits of Hormuz } \\
\text { and Malacca). As } \\
\text { an associate } \\
\text { country of the } \\
\text { IEA, China does } \\
\text { not formally } \\
\text { participate in the } \\
\text { IEA's emergency } \\
\text { mechanism. Gas } \\
\text { is rising in } \\
\text { strategic } \\
\text { importance. The } \\
\text { Russia-China gas } \\
\text { pipeline is due to } \\
\text { start by } 2020 . \\
\text { Shale gas } \\
\text { development is } \\
\text { slower than } \\
\text { expected. China } \\
\text { is now the third } \\
\text { largest importer } \\
\text { of LNG, mainly } \\
\text { from Australia } \\
\text { and Qatar }\end{array}$ & $\begin{array}{l}\text { China depends on } \\
\text { access to global } \\
\text { markets for a range } \\
\text { of commodities. It } \\
\text { could depend on } \\
\text { imports for as } \\
\text { many as } 39 \text { out of } \\
45 \text { key minerals by } \\
2020 . \text { A major } \\
\text { player in metals } \\
\text { and minerals } \\
\text { markets, China is } \\
\text { the key producer } \\
\text { of rare earth } \\
\text { elements and a } \\
\text { major importer and } \\
\text { processor of most } \\
\text { metals. } \\
\text { Circular-economy } \\
\text { policies could } \\
\text { dramatically } \\
\text { reduce import } \\
\text { needs and energy } \\
\text { consumption, } \\
\text { especially if } \\
\text { saturation of } \\
\text { metals and } \\
\text { minerals in the } \\
\text { economy is } \\
\text { reached sooner } \\
\text { than expected }\end{array}$ & $\begin{array}{l}\text { Increasing } \\
\text { interconnectedness } \\
\text { among Belt and } \\
\text { Road Initiative } \\
\text { countries. China } \\
\text { plans to increase } \\
\text { long-distance } \\
\text { exports (e.g. to } \\
\text { Central Asia and } \\
\text { Europe) from } \\
\text { western China } \\
\text { through investment } \\
\text { in ultra-high } \\
\text { voltage } \\
\text { transmission lines. } \\
\text { China's domestic } \\
\text { electricity market } \\
\text { reforms would } \\
\text { need to advance } \\
\text { alongside or ahead } \\
\text { of ambitious plans } \\
\text { for transmission } \\
\text { links with } \\
\text { neighbours }\end{array}$ & $\begin{array}{l}\text { Ambitious but } \\
\text { relative renewable } \\
\text { targets. China aims } \\
\text { to increase the share } \\
\text { of non-fossil energy } \\
\text { in energy } \\
\text { consumption to } 15 \% \\
\text { by } 2020 \text { and to } 20 \% \\
\text { by } 2030 \text {, and to } \\
\text { increase installed } \\
\text { renewable power } \\
\text { capacity to } 680 \mathrm{GW} \\
\text { by } 2020 \text {. China is } \\
\text { capturing the } \\
\text { low-carbon market: } \\
\text { it is the world's } \\
\text { largest manufacturer } \\
\text { of solar photovoltaic } \\
\text { cells and BYD is the } \\
\text { world's largest } \\
\text { electric vehicle } \\
\text { manufacturer }\end{array}$ & $\begin{array}{l}\text { Advancing } \\
\text { energy } \\
\text { governance is a } \\
\text { priority for the } \\
\text { G20 and was put } \\
\text { on the agenda by } \\
\text { China at the } \\
\text { Hangzhou } \\
\text { summit in 2016. } \\
\text { The Belt and } \\
\text { Road Initiative } \\
\text { will play an } \\
\text { important role, } \\
\text { from electricity } \\
\text { interconnections } \\
\text { to opportunities to } \\
\text { mine critical } \\
\text { materials. China } \\
\text { is now among the } \\
\text { leaders on climate } \\
\text { change and has a } \\
\text { strong strategic } \\
\text { interest in rapid } \\
\text { decarbonisation } \\
\text { globally. Bilateral } \\
\text { relations will } \\
\text { remain key -with } \\
\text { Russia, the } \\
\text { Middle East and } \\
\text { Australia }\end{array}$ \\
\hline & $\begin{array}{l}\text { Towards energy } \\
\text { independence? } \\
\text { The shale } \\
\text { revolution has } \\
\text { been a } \\
\text { game-changer. } \\
\text { US net imports of } \\
\text { petroleum are } \\
\text { equal to about } \\
25 \% \text { of US } \\
\text { petroleum } \\
\text { consumption- } \\
\text { the lowest level }\end{array}$ & $\begin{array}{l}\text { US dependence on } \\
\text { foreign sources of } \\
\text { rare earth elements } \\
\text { (REE) is "a very } \\
\text { real concern". It is } \\
\text { overwhelmingly } \\
\text { reliant on China } \\
\text { for REEs (more } \\
\text { than } 70 \% \text { of } \\
\text { imports, } 89 \% \\
\text { including indirect } \\
\text { imports). It has not } \\
\text { been economic to }\end{array}$ & $\begin{array}{l}\text { Power links with } \\
\text { regional } \\
\text { neighbours are } \\
\text { growing. The USA } \\
\text { is importing more } \\
\text { electricity from } \\
\text { Canada and } \\
\text { Mexico. Recent } \\
\text { and proposed } \\
\text { transmission } \\
\text { projects have the } \\
\text { potential to } \\
\text { increase }\end{array}$ & $\begin{array}{l}\text { Decentralised } \\
\text { leadership. } 29 \text { states } \\
\text { require electric } \\
\text { utilities to deliver a } \\
\text { proportion of } \\
\text { electricity from } \\
\text { renewables by a } \\
\text { given date. } \\
118 \text { mayors have } \\
\text { endorsed a goal to } \\
\text { power their } \\
\text { communities with } \\
100 \% \text { renewable }\end{array}$ & $\begin{array}{l}\text { US energy policy } \\
\text { has been } \\
\text { transformed by } \\
\text { the shale } \\
\text { revolution-oil } \\
\text { imports are under } \\
\text { control; gas is a } \\
\text { growing export } \\
\text { sector-primarily } \\
\text { constrained by } \\
\text { export restrictions } \\
\text { - and coal is } \\
\text { feeling the brunt }\end{array}$ \\
\hline
\end{tabular}


Table 1 (continued)

\begin{tabular}{|c|c|c|c|c|c|}
\hline & $\begin{array}{l}\text { Trade } \\
\text { dependencies }\end{array}$ & $\begin{array}{l}\text { Access to critical } \\
\text { metals for } \\
\text { low-carbon energy }\end{array}$ & $\begin{array}{l}\text { Cross-border } \\
\text { electricity and } \\
\text { interconnections }\end{array}$ & $\begin{array}{l}\text { Leadership in clean } \\
\text { energy technologies }\end{array}$ & $\begin{array}{l}\text { Energy-a key } \\
\text { component of } \\
\text { international } \\
\text { cooperation }\end{array}$ \\
\hline & $\begin{array}{l}\text { since } 1970 . \\
\text { Resuscitating a } \\
\text { collapsing coal } \\
\text { sector is a priority } \\
\text { for the Trump } \\
\text { administration, } \\
\text { but this will prove } \\
\text { challenging due } \\
\text { to the } \\
\text { competitiveness } \\
\text { of gas, and } \\
\text { increasingly of } \\
\text { renewables }\end{array}$ & $\begin{array}{l}\text { mine these } \\
\text { minerals in the } \\
\text { USA in recent } \\
\text { years }\end{array}$ & $\begin{array}{l}\text { bidirectional trade. } \\
\text { US electricity } \\
\text { networks are not } \\
\text { well connected. } \\
\text { The three main } \\
\text { interconnections } \\
\text { operate largely } \\
\text { independently from } \\
\text { each other with } \\
\text { limited } \\
\text { transmission } \\
\text { between them }\end{array}$ & $\begin{array}{l}\text { energy. There has } \\
\text { been strong reaction } \\
\text { at city and state level } \\
\text { to the decision to } \\
\text { leave the Paris } \\
\text { Agreement }\end{array}$ & $\begin{array}{l}\text { of cheap } \\
\text { alternatives. } \\
\text { Nevertheless, the } \\
\text { USA is more } \\
\text { energy-secure } \\
\text { than it has been } \\
\text { for decades. The } \\
\text { greatest risk is } \\
\text { that it loses } \\
\text { industrial } \\
\text { competitiveness } \\
\text { to countries at the } \\
\text { leading edge of } \\
\text { clean energy }\end{array}$ \\
\hline EU & $\begin{array}{l}\text { EU security } \\
\text { concerns are } \\
\text { focused on gas- } \\
\text { around } 90 \% \text { of oil } \\
\text { demand is met by } \\
\text { imports } \\
\text { (including from } \\
\text { Norway). The EU } \\
\text { spends five times } \\
\text { more on oil } \\
\text { imports than gas. } \\
\text { But gas supplies } \\
\text { are far more } \\
\text { concentrated: } \\
\text { almost half of } \\
\text { imports come } \\
\text { from Russia. } \\
\text { Member states } \\
\text { vary in their } \\
\text { national interests } \\
\text { due to, for } \\
\text { example, energy } \\
\text { mix and supply } \\
\text { routes }\end{array}$ & $\begin{array}{l}\text { A rising focus on } \\
\text { raw material } \\
\text { supplies. The EU } \\
\text { has identified } 27 \\
\text { critical raw } \\
\text { materials used in } \\
\text { its high-tech } \\
\text { manufacturing } \\
\text { sectors. In addition } \\
\text { to maintaining } \\
\text { competitiveness, } \\
\text { these materials are } \\
\text { needed for the } \\
\text { EU's push on } \\
\text { renewable energy. } \\
\text { The strategy is } \\
\text { designed to } \\
\text { support a range of } \\
\text { actions across } \\
\text { production, } \\
\text { efficiency and } \\
\text { trade }\end{array}$ & $\begin{array}{l}\text { The EU is leading } \\
\text { globally in } \\
\text { electricity market } \\
\text { integration-both } \\
\text { interconnections } \\
\text { and market } \\
\text { coupling. EU-wide } \\
\text { rules enable rising } \\
\text { electricity flows } \\
\text { and enhance } \\
\text { efficiency. The EU } \\
\text { is encouraging } \\
\text { links with } \\
\text { neighbouring } \\
\text { countries under its } \\
\text { Energy Union. } \\
\text { Member states are } \\
\text { learning to } \\
\text { integrate renewable } \\
\text { energy in large } \\
\text { volumes, although } \\
\text { the impacts on } \\
\text { utilities have not } \\
\text { been resolved }\end{array}$ & $\begin{array}{l}\text { Clean energy tech is } \\
\text { critical for climate } \\
\text { goals and } \\
\text { competitiveness. The } \\
\text { renewable energy } \\
\text { directive sets a } \\
\text { binding target of } \\
20 \% \text { final energy } \\
\text { consumption from } \\
\text { renewable sources by } \\
2020 \text {. The UK, } \\
\text { France and Germany } \\
\text { have all announced } \\
\text { dates for ending } \\
\text { internal combustion } \\
\text { engine sales, pushing } \\
\text { for EVs }\end{array}$ & $\begin{array}{l}\text { EU concerns: } \\
\text { Russian gas } \\
\text { imports, rising } \\
\text { cybersecurity } \\
\text { risks and the } \\
\text { impact of } \\
\text { renewables on } \\
\text { existing utility } \\
\text { business models. } \\
\text { But renewables, } \\
\text { EVs and } \\
\text { efficiency } \\
\text { measures are also } \\
\text { seen as a huge } \\
\text { opportunity. } \\
\text { Individual } \\
\text { member state } \\
\text { interests vary } \\
\text { according to their } \\
\text { energy and } \\
\text { industrial mix }\end{array}$ \\
\hline Japan & $\begin{array}{l}\text { Japan imports } \\
\text { almost all its } \\
\text { fossil fuels, which } \\
\text { amount to around } \\
90 \% \text { of energy } \\
\text { consumption, } \\
\text { following the } \\
\text { Fukushima } \\
\text { nuclear } \\
\text { shutdown. It is } \\
\text { also the largest oil } \\
\text { consumer and net } \\
\text { importer in the }\end{array}$ & $\begin{array}{l}\text { Dependence on a } \\
\text { single source for } \\
\text { rare earth elements } \\
\text { has led to a push } \\
\text { for diversification. } \\
\text { Japan aims to } \\
\text { secure } 60 \% \text { of } \\
\text { supply from } \\
\text { outside China and } \\
\text { has been importing } \\
\text { small amounts } \\
\text { from India. As for } \\
\text { other major }\end{array}$ & & $\begin{array}{l}\text { Renewable energy is } \\
\text { the key to Japan } \\
\text { diversifying away } \\
\text { from fossil fuel } \\
\text { imports as well as } \\
\text { nuclear. The } \\
\text { large-scale } \\
\text { introduction of } \\
\text { feed-in tariffs started } \\
\text { in } 2012 \text {, following } \\
\text { the Fukushima } \\
\text { disaster }\end{array}$ & $\begin{array}{l}\text { Energy security } \\
\text { priorities is one } \\
\text { factor in } \\
\text { Russia-Japan } \\
\text { rapprochement } \\
\text { over disputed } \\
\text { territories }\end{array}$ \\
\hline
\end{tabular}


Table 1 (continued)

\begin{tabular}{|c|c|c|c|c|c|}
\hline & $\begin{array}{l}\text { Trade } \\
\text { dependencies }\end{array}$ & $\begin{array}{l}\text { Access to critical } \\
\text { metals for } \\
\text { low-carbon energy }\end{array}$ & $\begin{array}{l}\text { Cross-border } \\
\text { electricity and } \\
\text { interconnections }\end{array}$ & $\begin{array}{l}\text { Leadership in clean } \\
\text { energy technologies }\end{array}$ & $\begin{array}{l}\text { Energy-a key } \\
\text { component of } \\
\text { international } \\
\text { cooperation }\end{array}$ \\
\hline & $\begin{array}{l}\text { world. Japan is } \\
\text { reliant on } \\
\text { seaborne imports } \\
\text { from the Middle } \\
\text { East through } \\
\text { maritime choke } \\
\text { points. } \\
\text { Two-thirds of } \\
\text { fossil fuel imports } \\
\text { pass through the } \\
\text { South China Sea }\end{array}$ & $\begin{array}{l}\text { economies, the } \\
\text { concern is a mix of } \\
\text { securing industrial } \\
\text { competitiveness in } \\
\text { high-tech sectors, } \\
\text { ambitions to } \\
\text { generate more } \\
\text { renewable energy, } \\
\text { and military } \\
\text { applications }\end{array}$ & & & \\
\hline India & $\begin{array}{l}\text { Despite } \\
\text { significant } \\
\text { domestic } \\
\text { resources, India is } \\
\text { heavily dependent } \\
\text { on overseas fuels, } \\
\text { importing } 80 \% \text { of } \\
\text { its oil. With } \\
\text { limited strategic } \\
\text { storage, it is } \\
\text { exposed to supply } \\
\text { disruptions. It is } \\
\text { the fifth largest } \\
\text { LNG importer- } \\
14 \text { mmtpa, mainly } \\
\text { used in power } \\
\text { generation and } \\
\text { fertiliser } \\
\text { production. It is } \\
\text { the largest coal } \\
\text { importer (from } \\
\text { Australia and } \\
\text { Indonesia), } \\
\text { despite having } \\
\text { large coal } \\
\text { reserves }\end{array}$ & $\begin{array}{l}\text { India could } \\
\text { become highly } \\
\text { dependent on } \\
\text { China for critical } \\
\text { minerals. One } \\
\text { assessment } \\
\text { identifies } 13 \\
\text { critical materials } \\
\text { needed to feed } \\
\text { India's growing } \\
\text { economy. Unless } \\
\text { these are produced } \\
\text { domestically, India } \\
\text { will become } \\
\text { import-dependent, } \\
\text { especially from } \\
\text { China. These } \\
\text { materials are } \\
\text { needed for } \\
\text { emerging tech } \\
\text { sectors and to meet } \\
\text { ambitious goals for } \\
\text { renewables, LEDs } \\
\text { and EVs }\end{array}$ & $\begin{array}{l}\text { Increasing access } \\
\text { to energy and grid } \\
\text { stability are } \\
\text { national priorities. } \\
240 \text { million people } \\
\text { have no access to } \\
\text { electricity, and } \\
\text { there is a huge push } \\
\text { to bring access to } \\
\text { villages. The } \\
\text { country has a } \\
\text { power surplus, but } \\
\text { power cuts are the } \\
\text { norm. Grid } \\
\text { integration between } \\
\text { states is required. } \\
\text { India has pioneered } \\
\text { LEDs to improve } \\
\text { efficiency and } \\
\text { reduce grid } \\
\text { pressure }\end{array}$ & $\begin{array}{l}\text { India is fast } \\
\text { becoming a leader in } \\
\text { low-carbon } \\
\text { technology. } \\
\text { Renewable power } \\
\text { targets are for } 175 \\
\text { gigawatts (GW) by } \\
2022 \text {, with } 100 \mathrm{GW} \\
\text { of solar, } 60 \mathrm{GW} \text { of } \\
\text { wind, } 10 \mathrm{GW} \text { of } \\
\text { bioenergy and } 5 \mathrm{GW} \\
\text { of small hydro. In } \\
2017 \text { a new record in } \\
\text { solar auction bids } \\
\text { was set at } 2.62 \\
\text { rupees/kWh }\end{array}$ & $\begin{array}{l}\text { India is set to } \\
\text { become a global } \\
\text { energy player, } \\
\text { driving demand } \\
\text { growth in the } \\
\text { coming years. } \\
\text { Energy security } \\
\text { concerns have } \\
\text { focused on oil } \\
\text { imports from the } \\
\text { Middle East. } \\
\text { Expanding access } \\
\text { to electricity and } \\
\text { investing in better } \\
\text { infrastructure are } \\
\text { top domestic } \\
\text { priorities. But } \\
\text { India is switching } \\
\text { its focus to } \\
\text { affordable clean } \\
\text { energy and the } \\
\text { associated } \\
\text { industrial sectors }\end{array}$ \\
\hline Brazil & $\begin{array}{l}\text { Push to secure } \\
\text { export market } \\
\text { share. Brazil's oil } \\
\text { exports are rising, } \\
\text { and in early } 2017 \\
\text { were } 65 \% \text { higher } \\
\text { than the previous } \\
\text { year, with a } \\
\text { record high of } \\
\text { more than } 1.46 \\
\text { million bpd. } \\
\text { Petrobras recently } \\
\text { cut petrol prices } \\
\text { below import } \\
\text { parity to regain }\end{array}$ & $\begin{array}{l}\text { An } \$ 8.4 \text {-billion } \\
\text { rare earth elements } \\
\text { deposit was } \\
\text { discovered in } \\
2012 \text {. In } 2016 \\
\text { production reached } \\
1,100 \mathrm{Mt} \text {, up from } \\
880 \mathrm{Mt} \text { in } 2015\end{array}$ & $\begin{array}{l}\text { Part of Brazil's } \\
\text { power system is } \\
\text { connected to } \\
\text { Argentina, } \\
\text { Uruguay and } \\
\text { Paraguay. These } \\
\text { interconnections } \\
\text { are used in case } \\
\text { there is excess } \\
\text { energy generation } \\
\text { in one country and } \\
\text { a lack of energy } \\
\text { supply in another, } \\
\text { or in emergency } \\
\text { cases }\end{array}$ & $\begin{array}{l}\text { Massive renewables } \\
\text { generation. Hydro } \\
\text { accounts for up to } \\
70 \% \text { of power } \\
\text { generation, making } \\
\text { Brazil the } \\
\text { second-largest } \\
\text { producer globally, } \\
\text { though droughts } \\
\text { caused by climate } \\
\text { change could pose a } \\
\text { challenge in the long } \\
\text { run. Brazil's energy } \\
\text { efficiency } \\
\text { programme }\end{array}$ & $\begin{array}{l}\text { There is } \\
\text { significant } \\
\text { potential for } \\
\text { cooperation with } \\
\text { China-Brazil } \\
\text { has expertise in } \\
\text { generation and } \\
\text { China in smart } \\
\text { meters and } \\
\text { electronics. } \\
\text { Chinese } \\
\text { companies are } \\
\text { influential in } \\
\text { Brazil's power } \\
\text { sector; along with }\end{array}$ \\
\hline
\end{tabular}


Table 1 (continued)

\begin{tabular}{|c|c|c|c|c|c|}
\hline & $\begin{array}{l}\text { Trade } \\
\text { dependencies }\end{array}$ & $\begin{array}{l}\text { Access to critical } \\
\text { metals for } \\
\text { low-carbon energy }\end{array}$ & $\begin{array}{l}\text { Cross-border } \\
\text { electricity and } \\
\text { interconnections }\end{array}$ & $\begin{array}{l}\text { Leadership in clean } \\
\text { energy technologies }\end{array}$ & $\begin{array}{l}\text { Energy-a key } \\
\text { component of } \\
\text { international } \\
\text { cooperation }\end{array}$ \\
\hline & $\begin{array}{l}\text { market share. } \\
\text { Even so, refined } \\
\text { petroleum } \\
\text { remains one of } \\
\text { Brazil's largest } \\
\text { imports due to the } \\
\text { scale of domestic } \\
\text { consumption }\end{array}$ & & & $\begin{array}{l}\text { mandates utilities to } \\
\text { invest } \$ 250 \text { million } \\
\text { annually }\end{array}$ & $\begin{array}{l}\text { foreign } \\
\text { investment funds, } \\
\text { they are seen as } \\
\text { likely bidders in } \\
\text { asset sales- } \\
\text { Eletrobras and } \\
\text { Cemig are } \\
\text { planning to } \\
\text { divest, including } \\
\text { some hydropower } \\
\text { assets }\end{array}$ \\
\hline $\begin{array}{l}\text { Saudi } \\
\text { Arabia }\end{array}$ & $\begin{array}{l}\text { Attempt to shift } \\
\text { away from critical } \\
\text { dependency on } \\
\text { export revenue. } \\
\text { Traditionally, } \\
\text { Saudi Arabia is } \\
\text { critically } \\
\text { dependent on } \\
\text { fossil fuel } \\
\text { exports, and is } \\
\text { economically } \\
\text { damaged by the } \\
\text { current low oil } \\
\text { prices. Vision } \\
2030 \text { is intended } \\
\text { to diversify and } \\
\text { shift away from } \\
\text { oil dependence } \\
\text { The IPO of Saudi } \\
\text { Aramco is the } \\
\text { first step in a } \\
\text { longer process }\end{array}$ & & $\begin{array}{l}\text { The state-owned } \\
\text { Saudi Electricity } \\
\text { Company } \\
\text { (SEC) plans to } \\
\text { privatise all its } \\
\text { power stations by } \\
2020\end{array}$ & $\begin{array}{l}\text { Target of generating } \\
9.5 \mathrm{GW} \text { per year } \\
\text { from renewable } \\
\text { sources by } 2023 \\
\text { through investments } \\
\text { of } \$ 30-50 \text { billion. } \\
\text { On-track to exceed } \\
\text { the target in } 2017\end{array}$ & $\begin{array}{l}\text { In } 2017 \text { Saudi } \\
\text { Arabia and China } \\
\text { deepened their } \\
\text { energy } \\
\text { relationship with } \\
\text { more than } 20 \\
\text { agreements on oil } \\
\text { investments and } \\
\text { renewable energy. } \\
\text { China has } \\
\text { discussed taking a } \\
\text { stake in Saudi } \\
\text { Aramco }\end{array}$ \\
\hline $\begin{array}{l}\text { South } \\
\text { Korea }\end{array}$ & $\begin{array}{l}\text { Lacking domestic } \\
\text { energy reserves, } \\
\text { South Korea } \\
\text { relies on imports } \\
\text { for about } 98 \% \text { of } \\
\text { its fossil fuel } \\
\text { consumption. } \\
\text { With no } \\
\text { international oil } \\
\text { or natural gas } \\
\text { pipelines the } \\
\text { country relies } \\
\text { exclusively on } \\
\text { tanker shipments } \\
\text { of LNG and crude } \\
\text { oil. South Korea } \\
\text { is highly } \\
\text { dependent on the } \\
\text { Middle East for } \\
\text { its oil supply }\end{array}$ & $\begin{array}{l}\text { South Korea has } \\
\text { traditionally been } \\
\text { heavily reliant on } \\
\text { China for its rare } \\
\text { earth imports and } \\
\text { has actively } \\
\text { attempted to } \\
\text { diversify its import } \\
\text { base }\end{array}$ & & $\begin{array}{l}\text { World leader in } \\
\text { energy storage } \\
\text { technology and is } \\
\text { developing the } \\
\text { world's largest } \\
\text { energy storage } \\
\text { system. South Korea } \\
\text { is heavily reliant on } \\
\text { fossil fuels, but has } \\
\text { announced plans to } \\
\text { phase out coal plants } \\
\text { and increase the } \\
\text { share of renewables }\end{array}$ & $\begin{array}{l}\text { Since the lifting } \\
\text { of sanctions, } \\
\text { South Korea has } \\
\text { increased } \\
\text { shipments of oil } \\
\text { from Iran, and } \\
\text { crude oil imports } \\
\text { have risen } 26.5 \% \\
\text { per year since } \\
2016 \text { as Iran has } \\
\text { sought to boost its } \\
\text { market share in } \\
\text { the context of } \\
\text { OPEC production } \\
\text { limits. The two } \\
\text { countries recently } \\
\text { signed } \\
\text { memoranda of } \\
\text { understanding on } \\
\text { energy } \\
\text { cooperation }\end{array}$ \\
\hline
\end{tabular}


International cooperation is a broader set of collaborative actions. Agreements are informal and compliance less enforceable. International cooperation tends to be negotiated through diplomatic channels, whereas global governance tends to occur via multilaterals. In practice there is considerable overlap between global governance and international cooperation, for instance, informal dialogue or cooperation between China and the USA in the run-up to COP21 facilitated the Paris Agreement.

It is widely accepted that energy systems are undergoing revolutionary change. But it remains unclear how global energy governance (institutions, mechanisms and norms) and international energy cooperation should respond. As a consequence of the high transaction costs associated with the reform of multilateral institutions, or indeed from the creation of new organisations, changes in the past have been slow and evolutionary. Yet abrupt economic and energy security crises have, at times, led to a more dramatic change-most notably after the 1973 oil shock.

However, building long-term coalitions and the structures to support them tends to be incremental, as the alignment of nation states' objectives requires multiple rounds of negotiations. A key question is whether the main trends and drivers reshaping energy technologies and producerconsumer dynamics will be reflected in a renewal of global energy governance. Another is what role China will play in this process.

\subsection{Strategic Direction of Travel}

China will face several key strategic decisions to achieve energy security and grid reliability, while accelerating the energy transition to improve air quality and lower emissions. These strategies will sit along a spectrum of unilateral to multilateral approaches, enabling policy-orientated or market-led approaches, as illustrated in Fig. 2.

All actions will require leadership from government, especially in the initial design and implementation, be they market or policy approaches. Market approaches are generally aimed at enabling rules-based commerce and trade, and ensuring a level playing field for energy markets. Policy approaches imply a more direct role for governments, such as in strategic oil storage or bilateral investment frameworks.

Overall, China's increased engagement on energy through cooperative mechanisms or multilateral arrangements is likely to lead to sustained, mutually beneficial outcomes from a wider number of countries. China's leadership could provide the foundations of trust and willingness to act.

The calculation of costs, benefits and risks by China's partners will change, depending on the engagement of great powers with multilateral organisations. If China focuses primarily on unilateral action and multiple bilateral agreements, confidence in wider collective approaches is likely to erode, resulting in fragile energy security, higher transaction costs, a breaking down of trade, reduced overseas investment and slower progress to reduce emissions. This risk would be amplified if the USA steps back from investing in rules-based trade and wider multilateral arrangements.

China will, of course, weigh the price of entry to any multilateral or plurilateral arrangementssuch as steps towards greater transparency-just as existing members will weigh the impact of Chinese membership or enhanced engagement (such as reduced voting shares), relative to the benefits. A potential leadership role for China in international energy cooperation is of particular relevance for the Belt and Road Initiative, where the trust and engagement of many partners is needed to underpin a win-win approach.

Given the open-market focus of many multilaterals, China will also need to consider making government interventions, not just domestically, but at the international level. While a command and control approach to international cooperation 


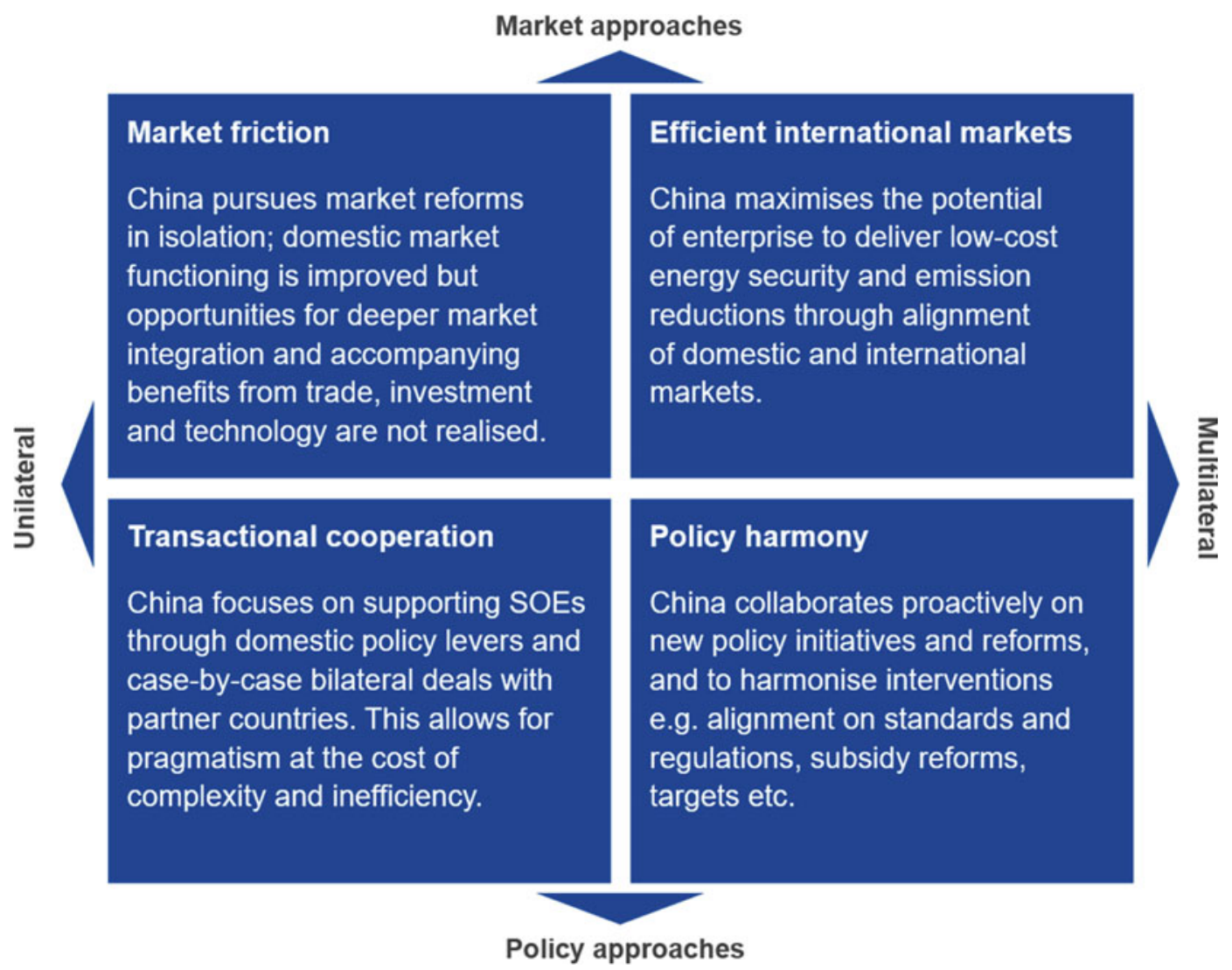

Fig. 2 The two key variables within which China's future strategic international actions should be considered. Note SOEs $=$ state-owned enterprises

and governance is possible, multilaterals tend to be designed to facilitate common rules and mechanisms for the efficient functioning of markets. If China continues its policy of moving from quantity- to quality-led growth, and liberalising markets domestically, then enhanced international cooperation and engagement with multilaterals in global economic governance is a natural course of action that will benefit all countries.

Taking this context as its starting point, this report sets out four priority areas for cooperation on global energy governance:

(1) making global energy governance fit for the future explores the potential governance and cooperative actions China could take with its international G20 partners to reform the IEA and make the G20 the hub of global energy governance;
(2) investment regimes for low-carbon, energy-secure transition explore investment and market mechanisms that China could expedite, enabling optimal allocation of capital across an increasingly complex set of energy sector objectives, while maintaining traditional energy security;

(3) security of supply of metals and minerals for future energy systems explores supply and demand measures that China could take to avoid supply shortages and trade disputes, while minimising the need for additional extraction capacity - both of which could prevent future limitations to clean energy deployment; and

(4) the shift from molecules to electrons explores a regional supply-side strategy that if adopted by China could accelerate electricity market harmonisation and trade, 
alongside an international infrastructure standardisation and investment strategy that could enable demand-side balancing-both of which could increase the reliability of future electricity networks as electrification and renewable generation accelerates.

\section{New Trends in International Energy Cooperation}

\subsection{Energy Security Has Traditionally Focused on Oil and Gas Supply Security and Price Stability}

Energy security has historically been regarded as a function of global geopolitics, with securing supply at affordable prices the key policy goal for import-dependent countries. This put the spotlight on avoiding a significant interruption of fuel - especially oil-produced in a few key countries and traded in global markets. At the national level, this conception of energy security was reflected in aspirations for energy independence, not least in the USA.

Given the concentration of conventional energy supplies in a handful of regions, much attention has been given to the risk of a supply disruption through critical maritime choke points like the Strait of Hormuz and the Strait of Malacca. Dependence on key gas pipeline routes, especially those between Russia and Europe, have also been a source of concern, although these are typically seen as important bilateral or regional issues rather than risks that can be managed by the international community.

This traditional concept of energy security has created a set of dynamics in past decades that consolidated into two distinct groups of producers and consumers, which joined forces to strengthen their respective bargaining power. The 1970s fuel price crisis still looms large over the institutions that emerged from that time to address the risk of a further disruption, not least the International Energy Agency (IEA). The International Energy Forum (IEF), and more recently the G20, have provided a valuable space for dialogue between producers and consumers, but it has rarely led to concrete policy action.

In recent years, there have been efforts to expand partnerships between OECD countries and emerging economies (especially China), since the latter are not members of the IEA but account for a rapidly increasing share of global demand. The OECD association agreements with China and India have made significant progress, especially on technical cooperation and knowledge sharing, but it remains challenging to ensure that existing international organisations reflect the evolving geographical distribution of energy consumption - as well as adapting to wider shifts in energy security.

\subsection{New Trends Are Changing the Nature of Energy Security}

Today, three key trends are reshaping the nature and focus of international energy cooperation and governance.

First, with increasing awareness of global climate threats, combined with rising concerns over air pollution at the national level, it has become clear to most governments and companies that energy security must be delivered alongside action to rapidly reduce greenhouse gas emissions internationally. The Paris Agreement of December 2015, adopted by all 196 parties of the United Nations Framework Convention on Climate Change (UNFCCC), was followed by reports of global temperature records in 2015 and 2016 - underscoring the scale of the challenge to keep global warming to well below $2^{\circ} \mathrm{C}$ above pre-industrial levels and pursue efforts to limit the temperature increase to $1.5^{\circ} \mathrm{C}$.

This means that most national, regional and city governments are factoring in climatefriendlier or lower-carbon options in their national energy planning, especially for the power sector. Since the aggregation of all current nationally defined pledges to the Paris Agreement fall short of the $2^{\circ} \mathrm{C}$ target, 2018 will witness the beginning of the "facilitative 
dialogue" to revisit those pledges before the agreement enters into force in 2020 . The decision of the USA to withdraw from the Paris Agreement (see Box 2) is a blow to this process, but it could also be a catalyst for higher ambition among other parties and at the city and state level in the USA itself. The EU, China, India and other key countries have restated their ongoing commitment since the US announcement.

Taking a longer view, policy activity on climate change has undoubtedly broadened and deepened in recent decades. In fact, the number of climate change related laws and policies adopted globally has doubled every 4-5 years since 1997 to more than 1,250 . The annual peak in new legislation and executive action occurred in 2010, with 127 laws passed, but fell to 45 in 2016. This slowing in recent years suggests a shift towards implementation and consolidation (Fig. 3).

Domestic concerns over air pollution are another important driver of change, along with other localised environmental impacts and water scarcity. The World Health Organization (WHO) estimates that $92 \%$ of the global population lives in regions where air quality is below the minimum recommended WHO guidelines, resulting in an estimated 3 million premature deaths per year. Communities living in the Western Pacific and South East Asia experience the greatest proportion of premature deaths, $88 \%$ as a direct result of poor air quality due to the burning of coal and biomass. The health benefits of switching from coal are clear: in the USA between 1945 and 1960, winter all-age mortality rates dropped by $1 \%$ as a direct result of switching from coal gas, and by $3 \%$ in winter infant mortality.

\section{Box 2: The USA and the Paris Agreement}

In June 2017, President Trump announced that the USA will withdraw from the Paris Agreement. Losing the world's second largest emitter was a heavy blow to the agreement, which is less than two years old and has yet to be implemented. Yet Paris was designed to withstand upheavals of this sort. It has a flexible structure based on voluntary pledges to reduce emissions. Governments set these individually based on national circumstances, rather than through quid pro quo negotiations as happens during trade rounds at the World Trade Organization. Consequently, US withdrawal doesn't destabilise the agreement by short-changing other countries.

It also seems unlikely to trigger a domino effect. Many countries, cities and companies have confirmed their strong commitment to implementing the Paris Agreement, including 12 US states (accounting for a third of US GDP) and more
Fig. 3 Cumulative number of climate laws passed in 159 countries

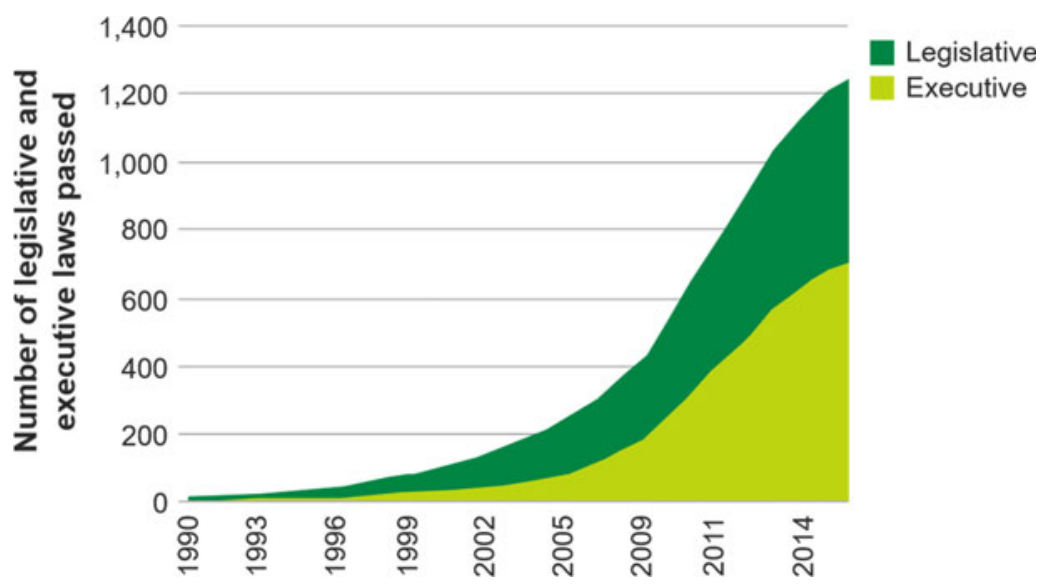


than 200 mayors. A "G6" statement omitting the USA in the recent G7 leaders' communiqué reaffirmed their commitment. China and the EU, the first and third largest emitters in the world, are set to announce a new partnership on climate action. India, the fourth largest emitter, has also reconfirmed its commitment to Paris.

The decision has obvious implications for global emissions, but the impact might not be as large as expected for three reasons. First, even if the USA had decided to remain in the agreement, it would probably not meet its emissions pledge, which President Trump has criticised. It is, after all, non-binding. Second, much American policy and regulatory action on climate change happens at the state level, and many states remain committed to emissions reduction. Third, emission reductions are increasingly the result of market forces rather than national targets. Republican Texas produces a quarter of all US wind power because it makes economic sense. Shale gas has squeezed coal out of the US power mix because it is cheaper.

The second trend reshaping the nature of international energy cooperation can be seen in the policy encouragement for lower-carbon options. This is occurring alongside dramatic technological advances and declining prices, which in turn are driving the transformation of energy markets and investments, changing the terms of energy choices. The most notable transformations are the shale revolution in the USA, the falling cost of renewable energy, and digitalisation of the electricity sector. For instance, the technology-driven shale revolution in the USA has enabled oil production to more than double, from a low of $4.3 \mathrm{mb} / \mathrm{d}$ in September 2008 to $9.6 \mathrm{mb} / \mathrm{d}$ in July 2015. Output dipped as the oil price crashed in late 2014, but at the start of May 2017 production stood at 9.3 $\mathrm{mb} / \mathrm{d}$. The well-known decline in solar photovoltaic prices continues, with prices in India down almost $40 \%$ between 2016 and 2017.

This transformation of energy markets and investments is driving the third key shift, from molecules to electrons. With emerging electricity network expansion, electric vehicle (EV) and storage capacity growth are likely to complete a self-reinforcing circle, and drive new patterns of trade, new vulnerabilities and new interdependencies. Further, EV lithium-ion battery manufacturing capacity is set to increase more than sixfold between 2016 and 2020, with manufacturers selling new lithium-ion batteries into the stationary storage market at low prices.

These three structural shifts or drivers are challenging traditional conceptions of energy security and shifting the focus of energy policymakers. These can be separated into four areas, although in practice they are highly interconnected:

- from fuels to technologies: in light of the technology revolution in shale, renewables and, on the demand side, the focus on competitiveness, are as much about technology access and leadership as about securing fuel supplies;

- from molecules to electrons: a growing focus on efficient and resilient electricity systems that can manage variable production from renewables, integrate battery storage and EVs, and deliver investment in grid infrastructure;

- access to other minerals and metals: the shift in materials needed for low-carbon energy will raise new questions for energy and resource governance. Examples of key materials include lithium, cobalt, rare earth elements and precious metals; and

- digital disruption: as in other sectors, digital technology promises to deliver new opportunities for efficiency, from demand-side management to autonomous vehicles. In parallel, it has also increased concerns over cybersecurity in the energy sector. 
Fig. 4 Global primary energy consumption by fuel type, 1850-2015. Source Chatham House analysis

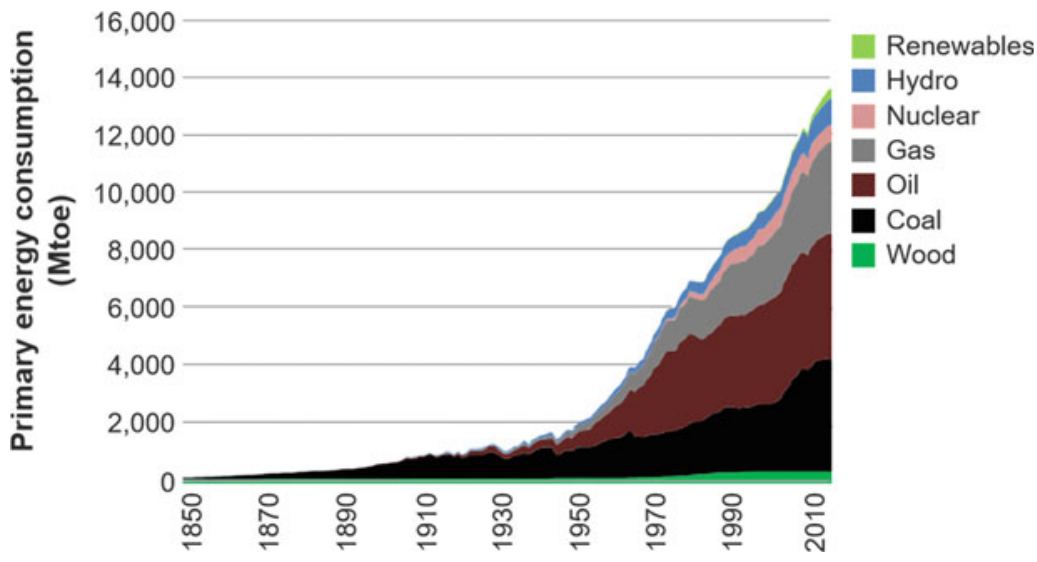

\subsection{Energy Demand Growth and Access to Energy}

Global primary energy consumption growth has proven remarkably stable since 1850 , growing at $2.4 \pm 0.08 \%$ per year, and it doesn't appear to be slowing. Current consumption is around 77 gigajoules (GJ) per capita; in the developed world it is 177 GJ per capita. If the projected 11 billion global population in 2100 consumes the equivalent of the developed world today, energy consumption will increase fivefold. Such a fivefold increase is equivalent to a growth rate of $1.9 \%$, below but remarkably similar to the historic growth rate since 1850. Relative to 2014, the IEA's $20402^{\circ} \mathrm{C}$ scenario implies an increase of $9 \%$ in primary energy consumption, a significant departure from the $85 \%$ increase implied by historical trends. Meeting this target will require redoubling policy support for the deployment of new technologies, alongside significant investment in energy efficiency. At the same time, we may be on the cusp of a demand revolution, which makes it possible to do much more with much less (Fig. 4).

Providing power for the 1.2 billion individuals who in 2016 lacked access to electricity is no easy task. While this figure is 15 million fewer than in 2015, 244 million people in India and 632 million in sub-Saharan Africa still lack access. There have already been significant shifts in geographical patterns of energy consumptioncaused primarily by the growth of China, India and other emerging economies - which have driven nearly all growth since the turn of the 21 st century. Between 2000 and 2015 for example, China was responsible for more than $40 \%$ of global oil demand growth, while consumption in Japan, the USA and EU fell by $20 \%$ (Fig. 5).

Several recent studies have found that increasing per capita wealth or income by $1 \%$ decreases per capita energy intensity by around $0.3 \%$; in other words, wealthier countries tend to have a lower energy intensity. Further, those technological advances which have reduced energy intensity correlate with those that have increased per capita wealth. In other words, decreases in energy intensity are due to countries becoming wealthier, not by producing the same level of wealth with less energy. This technologically enabled wealth creation and reduction

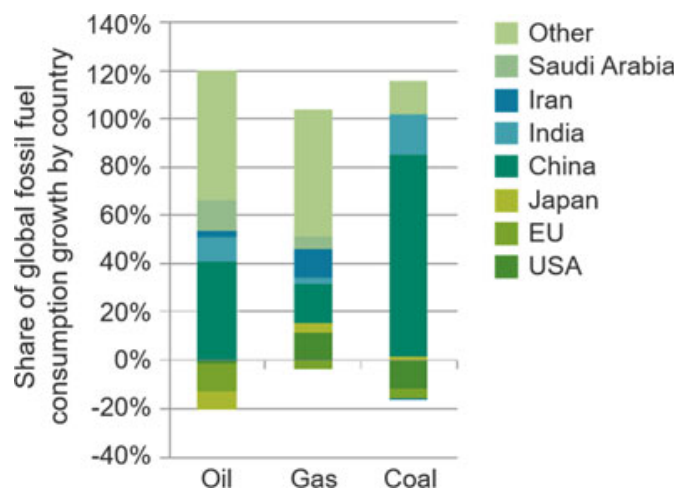

Fig. 5 Share of global fossil fuel consumption growth by country, 2000-15. Source Chatham House analysis 
in energy intensity is synonymous to the move from industrial to service sector driven growth, occurring in countries across South East Asia. This trend of quantity to quality is exemplified by electrification - the greater use of electrons rather than molecules - alongside digitalisation and the growing Internet of things.

\section{Box 3: Critical areas for a $2^{\circ} \mathrm{C}$ world and the energy transition}

The aggregate of all nationally determined contributions pledges far from meets the $\mathrm{CO}_{2}$ reductions required under the Intergovernmental Panel on Climate Change mitigation pathways. Increased political ambition and expansion of climate policies and legislation are, therefore, required to ensure the world doesn't exceed $2^{\circ} \mathrm{C}$, which could result in runaway global warming.

Turning to the International Energy Agency's New Policies Scenario (NPS), which represents 2016 global climate policies, by 2040 a $2{ }^{\circ} \mathrm{C}$ world will require $16.7 \%$ less primary energy consumption relative to the NPS scenario. Renewable generation, as a share of the energy mix, will need to increase by $70 \%$ (excluding biomass and hydropower). Coal, oil and gas consumption will need to decline simultaneously by $52 \%, 30 \%$ and $23 \%$ respectively (Fig. 6). Given that the past 25 years has witnessed coal and oil growth of $71.2 \%$ and $42.5 \%$ respectively, these reductions require a reversal of investment trends, alongside a reversal in consumption and production of fossil fuels (Fig. 7).

Ensuring the appropriate level of investment in energy infrastructure will be critical. Figure 8 shows the difference in capex accumulation by fuel type, alongside additional investment in the power and energy efficiency sectors, under the NPS and $2^{\circ} \mathrm{C}$ scenarios. This climate policy driven imperative is compounding a strong and growing argument that the oil, and potentially the gas sector, is in limbo.

Investment in conventional exploration and production $(\mathrm{E} \& \mathrm{P})$ projects is at historic lows. Many projects are high cost and high risk, which combined with low oil prices, is limiting companies' ability to self-finance new E\&P projects.

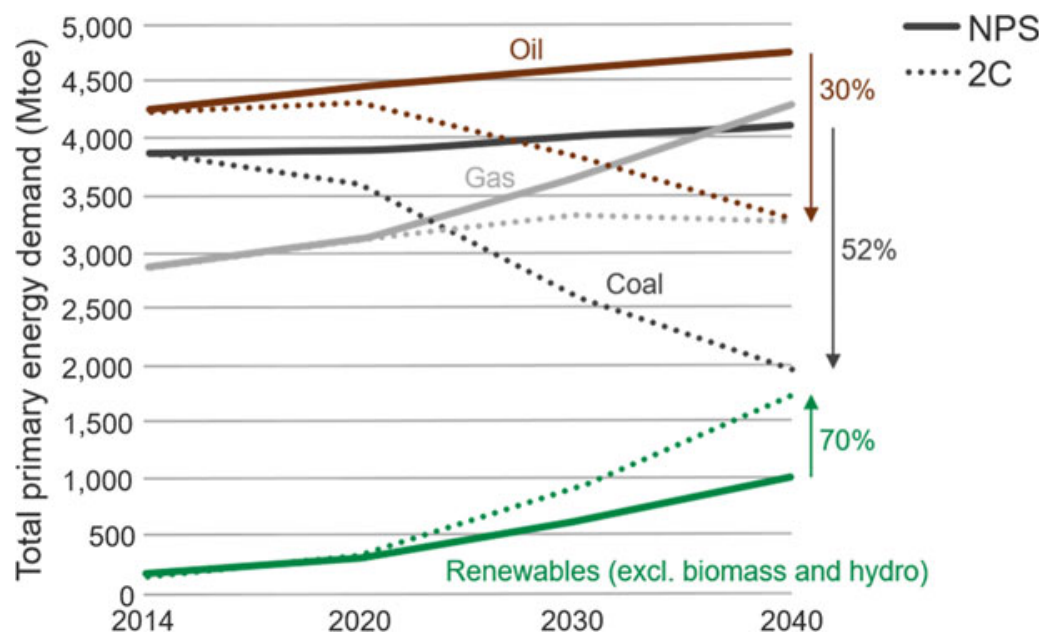

Fig. 6 Global energy mix. Source Chatham House analysis 
Fig. 7 Global electricity generation. Source Chatham House analysis
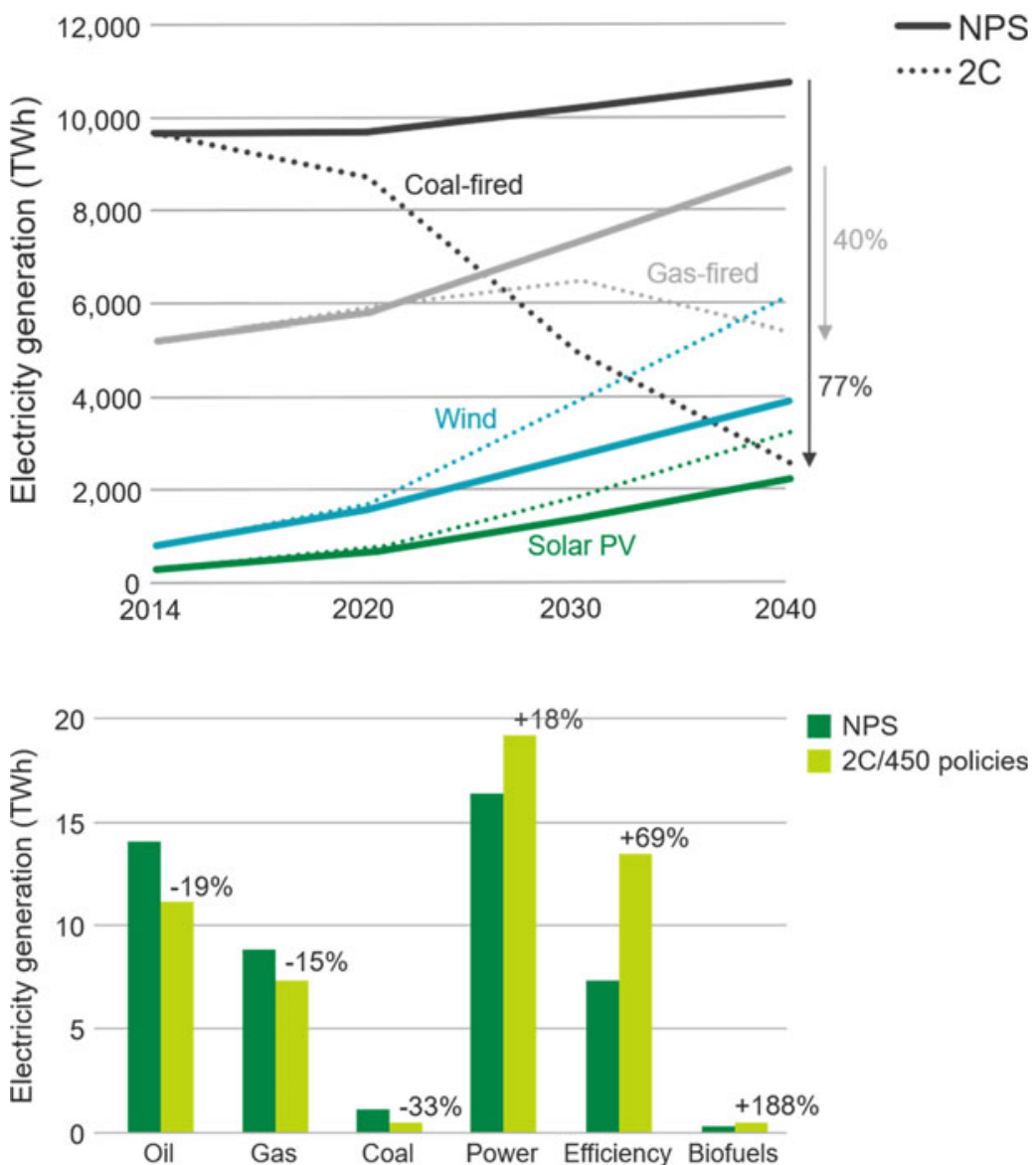

Fig. 8 Global energy accumulated capex in the energy industry, 2012-35

\subsection{New Concepts of Energy Security and Energy Cooperation}

Traditional energy security dialogues and mechanisms, including those for oil and gas security, will continue to play a key role in delivering energy security, perhaps for several decades. Today, these remain the focus of policymakers, especially in countries where demand and exports are rising. The challenge for policymakers will be how to adapt these instruments to new market realities and shifts in the energy mix in order to remain relevant and effective.

Meanwhile, the complex nature of these shifting trends points to a need for mainstream energy governance within a range of international processes, especially those related to shifting finance at scale. Pressure to phase out coal and reduce carbon liabilities in the global financial structure, for instance, will have profound impacts on global energy systems.

Moreover, gaps in the existing structure could be increasingly apparent given the shifts in energy markets, technology and politics. Technical and policy support for energy efficiency and clean technologies has become a core competency of institutions such as the IEA, and new institutions focused solely on renewable energy, such as the International Renewable Energy Agency have emerged, as well as initiatives such as Mission Innovation and Breakthrough Energy. But until now, there has been a division between traditional oil market security questions and the wider conception of energy security, which is arguably now essential.

It remains challenging to enhance the legitimacy and representativeness of current energy governance structures through reform processes. 
In part due to difficulties around potential treaty reform, voting rights and other areas, some of the fastest-growing energy markets-including China-have been left with relatively little influence over international energy cooperation at the IEA. This is not only a question for energy policy - it reflects, for example, how China and other rising powers have struggled to make their voices heard at the International Monetary Fund and World Bank, and initial US reservations about the Asian Infrastructure Investment Bank.

Following the financial crisis, the G20 has increased its role in energy, bringing in both established and emerging energy powers. The G20 has delved into traditional energy governance-codified in its energy principles-but also provides a platform for innovative governance reforms with cross-cutting impacts for energy systems. These range from the G20 Task Force on Climate-related Financial Disclosures to the introduction of the Green Finance Study Group during China's presidency of the G20 in 2016. The German government also made carbon prices a priority during its presidency of the G20 in 2017.

\section{Major Factors Driving Global Energy Governance Transformation}

\subsection{Shifts in Energy Consumption Patterns and the Role of Key Institutions and Groupings}

The global energy landscape is being redrawn as the weight of new consumers diminishes the market power of the old. Non-OECD oil demand overtook that of the OECD in 2011, and China is now the world's largest renewable energy investor, around double that of the USA. The growing market power of emerging economies, as well as the changing fossil fuel balance in global and national energy mixes, has led to questions about the representativeness and agency of existing mechanisms and groupings.
Two prominent examples are the International Energy Agency (IEA), where voting shares still reflect consumption levels of the 1970s and emerging economies are not members (although they have recently explored partnership arrangements); and the Asian Infrastructure Investment Bank (AIIB), established by China in 2016 in response to a perceived gap in the existing international arrangements.

As Fig. 9 shows, the IEA member countries' share of primary energy consumption fell from 61 to $42 \%$ between 1980 and 2013. IEA member countries' share of production also dropped from 41 to $30 \%$ over the same period. This declining representation undermines the IEA's ability to fulfil its core functions. In 2009 one of the IEA's founding fathers, Henry Kissinger, put the dilemma to the governing board:

[The fact that] nations outside of the OECD (and
the IEA) now account for the majority of global
energy consumption is a change of great signifi-
cance...the fact that this bloc of rising major
consumers resides outside of the cooperative
framework of the IEA compromises the organiza-
tion's ability to effectively address global energy
security and climate concerns and concurrently
deprives these nations of the full benefits of IEA
membership.

Today, the G20 - which includes many of the IEA member countries but also emerging economies-represents a much greater proportion of energy markets and greenhouse gas emissions. Its members accounted for $82 \%$ of consumption and $73 \%$ of production in 2013 , as well as around $80 \%$ of greenhouse gas emissions. The G20 collectively represents almost 40\% more primary energy consumption and production relative to the IEA or OECD. Even if China was to join the IEA, the G20 would still represent around $18 \%$ more primary energy consumption and around $24 \%$ more production-one reason IEA Association Agreements have also been developed with Indonesia, Thailand, Singapore, Morocco and India.

Of course, these organisations vary considerably in nature and in their expectations of membership. The IEA is a treaty-based organisation and members agree to rules and 


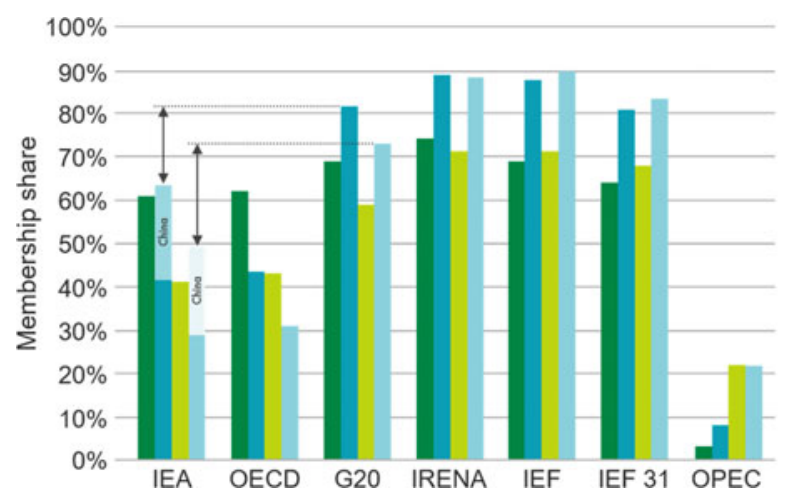

Consumption 1980

Production 1980

Consumption 2013

Production 2013
Fig. 9 Selected international energy and governance membership organisations and their respective primary energy consumption and production share of global totals.
Note Membership in 1980 represented by current membership. Source Chatham House analysis of data from the U.S. Energy Information Administration (EIA)

action within the G20 is the consolidation of the G20's Energy Sustainability Working Group role (Figs. 11 and 12).

\subsection{The Challenge of Phasing Down Coal}

There is wide agreement that phasing down coal within the global energy mix is critical to achieving the Paris Agreement, as well as safeguarding public health and the environment. Analysis from University College London, UK, for example, suggests that more than $80 \%$ of global coal reserves must remain unburned in order to retain a $50 \%$ chance of keeping the climate within $2^{\circ} \mathrm{C}$ of warming, even with the application of carbon capture and storage.

Norms have emerged in multilaterals such as the World Bank and across governments including the UK, which have agreed not to finance coal-fired power except in the most extreme circumstances. At the same time, a growing fossil fuel divestment movement has emerged in OECD countries, helping to push institutional investors and others away from coal and the most polluting fossil fuels; this now includes more than 700 institutions and around $\$ 5.46$ trillion assets under management.

Real-world trends are underpinning these emerging norms around the future of coal. First is the decline of the coal industry: in the USA, coal engage with this working group. Another area of 


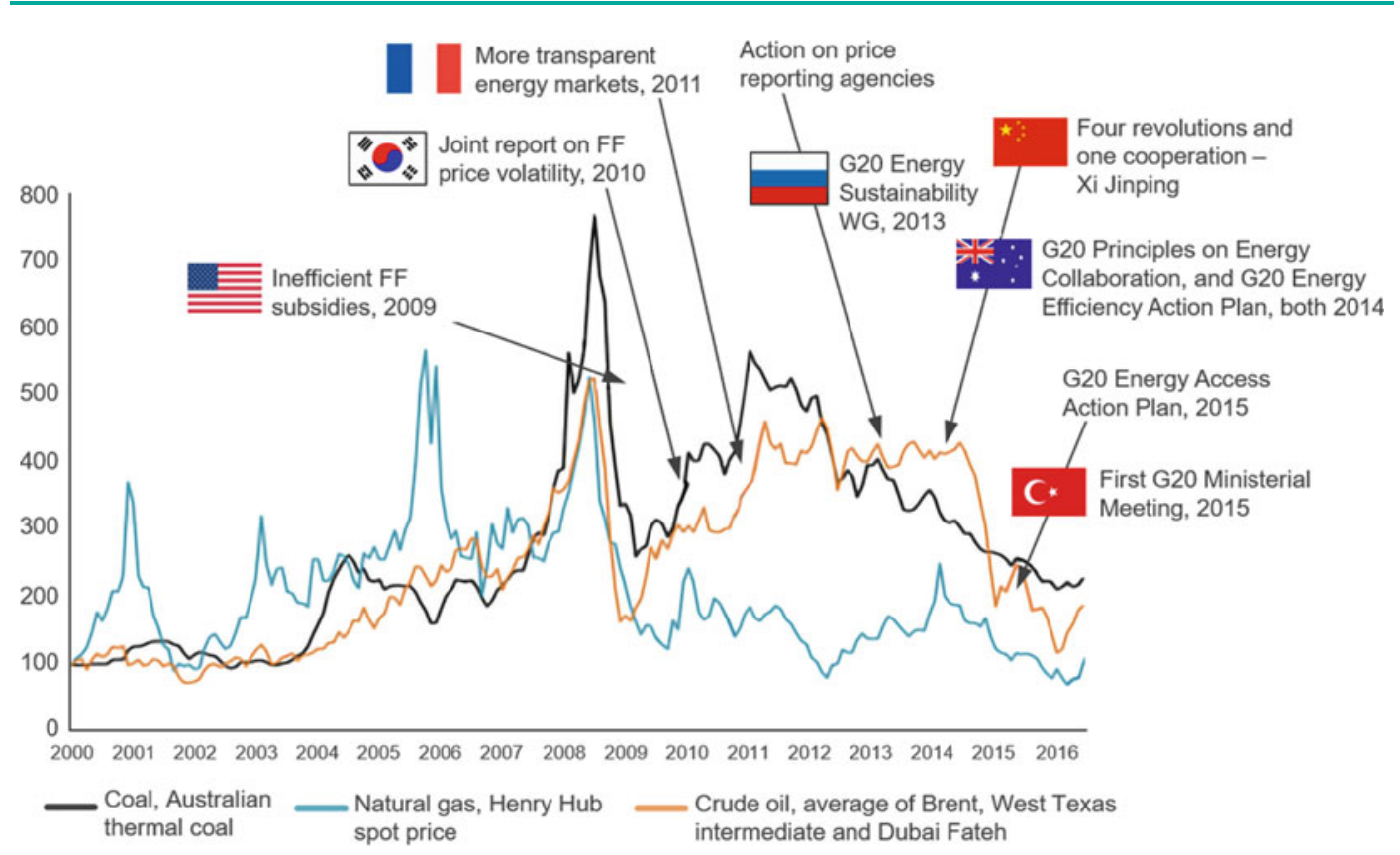

Fig. 10 G20 initiatives on energy. Note FF = fossil fuels; WG = Working Group primary energy demand and production (2013). Source Chatham House analysis of EIA data
Fig. 11 G20 share of

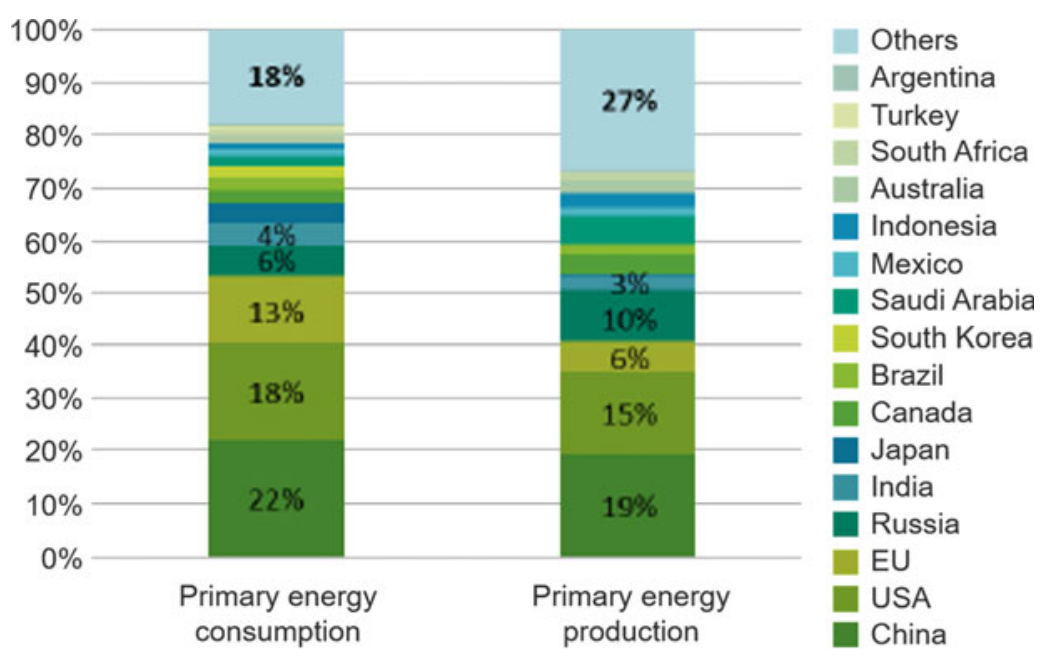

has been displaced by cheap gas, which contributed to the country's largest coal producer, Peabody, filing for bankruptcy protection in 2016. Elsewhere major miners have divested their steam coal assets into bad banks, such as BHP's spin-off South32; or to emerging market state-owned enterprises, such as Rio Tinto's divestment of its Australian coal assets to
Chinese SEO Yancoal in early 2017. Second, is the impact of the rapidly declining price of renewables - even in coal strongholds like South Africa and India - where renewable auctions and wind power in particular continue to set record low prices.

Major coal producer-consumers have made similar commitments at home, not least because 
Fig. 12 Reserves and current 100\% production (2015). Source Chatham House analysis of BP Statistical Review

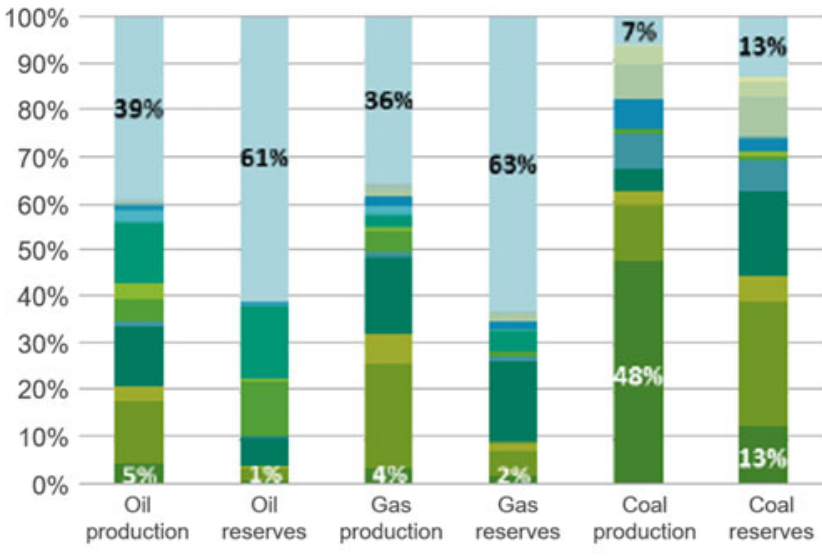

Others

Argentina

Turkey

South Africa

Australia

Indonesia

Mexico

Saudi Arabia

South Korea

Brazil

Canada

Japan

India

Russia

EU

USA

China they typically align with broader strategies to restructure domestic industries and drive prosperity through innovation. China's coal consumption may have peaked as early as 2013 according to the IEA, and it is expected to plateau over the coming 5-10 years. China's 13th Five-Year Plan (2016-20) and nationally determined contributions (NDC) to the Paris Agreement have set it on course to reduce coal production and consumption-China may even be able to meet its NDC goals before the 2030 target.

Meanwhile, India's coal demand is currently growing slower than expected-this is important since the IEA expects India to account for $50 \%$ of global growth in coal-fired power to 2040 . Coal stockpiles have been growing, and domestic producers have been asked to slow production. India has introduced coal taxes, $40 \%$ of which are earmarked to subsidise renewables. South East Asia markets-where coal demand is expected to triple to 2040, according to the IEA's New Policies Scenario-have also set ambitious renewable energy targets in their NDC submissions.

\section{Box 4: The role of gas}

Current global gas-fired power station capacity factors are just below $40 \%$, compared to $55 \%$ for coal-fired. As more renewables are integrated into the grid, the ability of gas-fired power stations to respond quickly to variations in the supply-demand balance will become essential. In conditions of consistently varying output, gas generators perform better relative to coal, both in terms of economic and emission performance (Fig. 13).

Developments in China reflect those globally, with regulators in the process of reforming gas markets and the government setting ambitious targets within the 13th Five-Year Plan (2016-20) to almost double consumption to $350-380$ billion cubic metres $(\mathrm{bcm})$ by 2020 . This would require a $13-15 \%$ compound annual growth rate which, given the $12 \%$ growth in the first 10 months of 2016, appears likely. In 2014, the power sector accounted for around $14 \%$ of the $187 \mathrm{bcm}$ of gas demand in China, under the 13th FYP; this is set to rise to $26-29 \%$ by 2020 . Globally, gas generation capacity has grown from 0.84 terrawatts (TW) in 2000 to $1.47 \mathrm{TW}$ in 2015 , an increase of $75 \%$, but still below the coal capacity of 1.85 TW.

The shift from coal to gas in the power sector is likely to be accompanied by a shift in the residential space heating sector. In the 1980s, coal provided less than $1 \%$ of space heating energy demand in the USA. China is somewhat behind. In 2012, in the urban regions of northern China, district 
Fig. 13 Liquefied natural gas (LNG) demand by region. Source Chatham House analysis

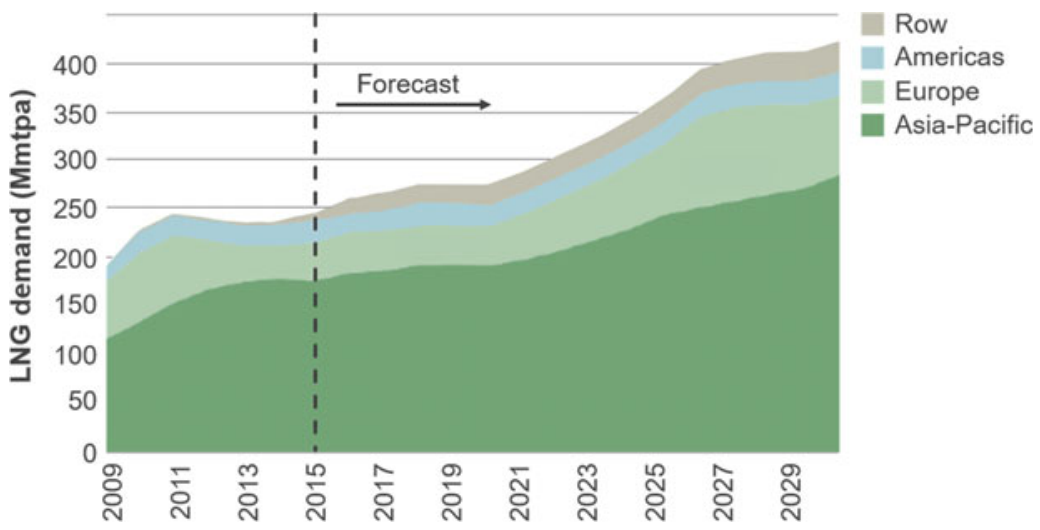

heating systems warmed $45 \%$ of the urban floor area (the world's largest; $90 \%$ of this heat was fuelled by coal). With rising pressure on the Chinese government to reduce local air pollution, it is no surprise that the 13th FYP targets increased gas consumption in the residential sector. In the first quarter of 2016, a larger than expected switch from coal to gas in the heating sector pushed Chinese gas consumption to a record high.

This shift to gas should be viewed within context-the IEA $2^{\circ} \mathrm{C}$ scenario holds global primary consumption of gas to a modest $14.1 \%$ increase between 2015 and 2040 , equivalent to $0.5 \%$ annual growth.

\subsection{Transformation of the Electricity Sector}

Policy encouragement for lower-carbon, climate friendly options has led to the rapid deployment of renewable energy, especially wind and solar. This has resulted in significant challenges for existing utility business models and the need for electricity market reform in countries that are further down the curve of renewables deployment. Although electricity markets are primarily the concern of national or subnational authorities, there is growing appetite for technical cooperation and experience sharing in this area of energy policy. In particular, how to learn from the successes and failures of countries in the vanguard, while recognising the very different market contexts and designing appropriate policy responses accordingly.

In electricity markets where renewables have significantly increased their share of production, electricity prices have declined significantly. For instance, in California, where solar photovoltaic provides $13.2 \%$ of electricity, the productionweighted average price of utility-scale solar fell by $38.1 \%$ between 2014 and 2015, causing a $25.5 \%$ decline in gas power prices. Falling power prices are the result of the merit-order effect, where relatively more expensive fossil fuel generators are displaced by renewable generators. These structural declines in prices in power networks with a high penetration of renewables is resulting in fossil fuel generators extracting value during periods of low renewable generation, when they can rapidly ramp up output.

Renewable energy prices keep falling, but even in 2014 onshore wind was delivering electricity in Europe at $\$ 50$ per megawatt-hour (MWh) without subsidies, compared to \$45-140/MWh for fossil fuel power plants. In August 2016, Chile witnessed power auctions in which solar won contracts at half the price of coal power, resulting in power prices collapsing 
Fig. 14 Levelised cost of electricity (LCOE) of various generators-global, historical, Chinese and US forecasts. Source Chatham House Analysis

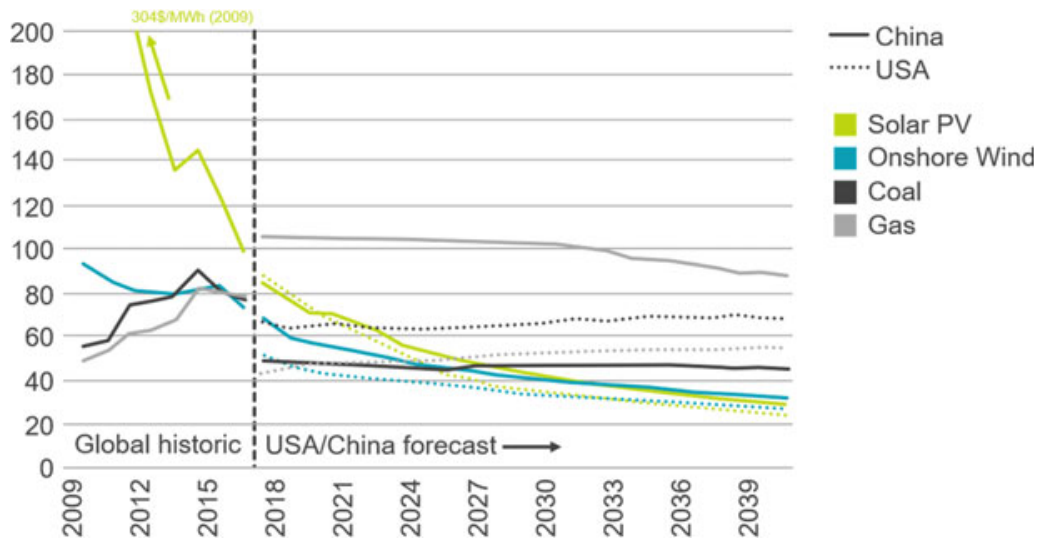

by $40 \%$. In December 2016 the average capex of solar fell below that of onshore wind in 58 non-OECD countries, a significant milestone as solar prices have fallen far faster than most analysts had forecast.

The historical trend of costs rising for fossil fuel generators while those for renewables fall is clear. As Fig. 14 illustrates, between 2009 and 2016 the global levelised cost of electricity (LCOE) for coal- and gas-fired power stations increased by $63 \%$ and $39 \%$ respectively, while solar and onshore wind declined by $67 \%$ and $20 \%$ respectively. In China, both solar and onshore wind LCOEs are likely to be cheaper than coal and gas by 2028; both are already cheaper than gas power stations. In the USA, the point at which solar and wind become cheaper than coal and gas is likely to occur as early as 2024. In Germany solar and onshore wind LCOEs are already cheaper than both coal and gas generators, while in the UK onshore wind LCOE is already lower than coal generators.

Currently, $42 \%$ of primary energy is used to produce electricity, which in turn makes up $18 \%$ of final energy consumed by end users. With electricity increasingly supplied by renewables, the governance of low-carbon energy will play an important role in ensuring secure and affordable energy, improving air quality and mitigating climate change. As Fig. 15 shows, renewables' share of the energy mix increased from a negligible base in 1990 to $2.8 \%$ of primary energy consumption in 2015.
Globally, electricity generation increased by $29.2 \%$ between 2006 and 2015, while renewables' share of this generation increased from 19.7 to $24.2 \%$ over the same period. This trend of renewables increasing its share of electricity supply is particularly prevalent in the EU, where renewables almost doubled its share from 15.8 to $30 \%$ in 2006-15. China, by comparison, increased its share from $16.1 \%$ in 2006 to $25 \%$ in 2016 (Fig. 16).

This shift in the energy mix towards renewables is likely to accelerate, given that renewables increased its share of new capacity additions from $8.5 \%$ in 2002 to $42.6 \%$ in 2015 (Fig. 17). Globally, China looks set to continue to be the single greatest contributor of new renewable capacity additions. The shifting capital allocation of some independent oil companies is acknowledgement of this shift. For example, Equinor invested $\$ 2.3$ billion in offshore wind, and by 2030 aims to invest $15-20 \%$ of capital expenditure in renewables.

Electrification of transport and heating (the shift from molecules to electrons) is likely to accelerate over the next 15 years, increasing the share of global energy supplied by the electricity sector. By 2040, 25\% of the global car fleet is expected to be electric, which could increase global electricity demand by $11 \%$, relative to 2015. This would add 2,700 terrawatt-hours to global electricity demand, more than double the global generation from wind and solar in 2015 (Figs. 18 and 19). 
Fig. 15 Global primary energy consumption. Source Chatham House analysis

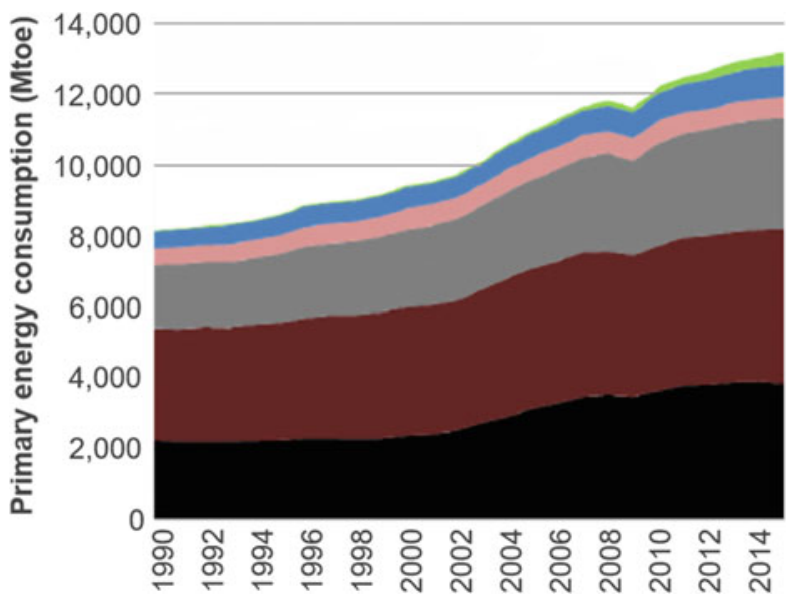

Fig. 16 Global power generation by source. Source Chatham House analysis

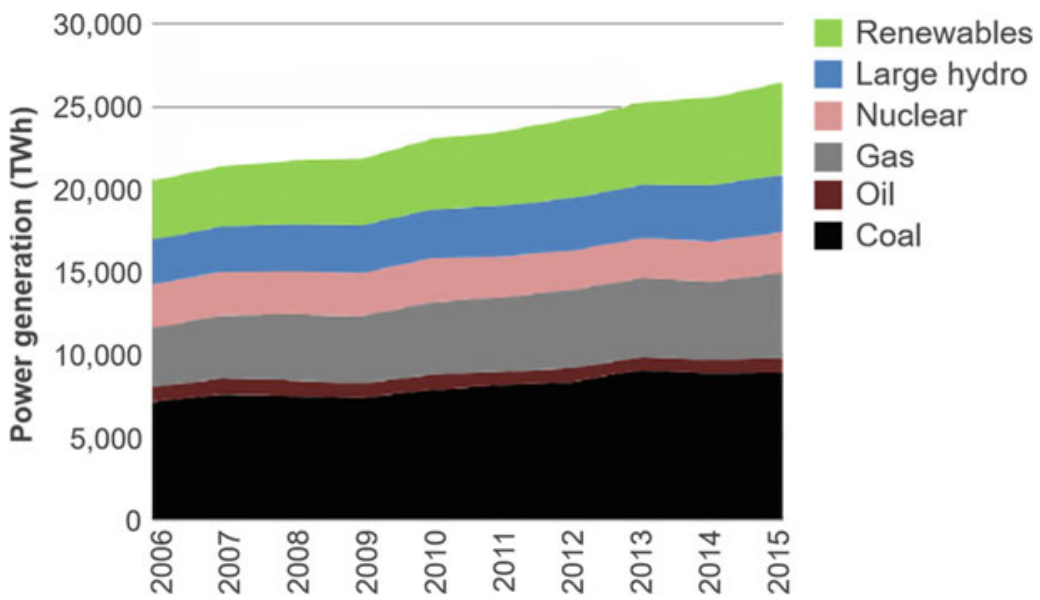

Fig. 17 New-build capacity additions, 2001-15. Source Chatham House analysis

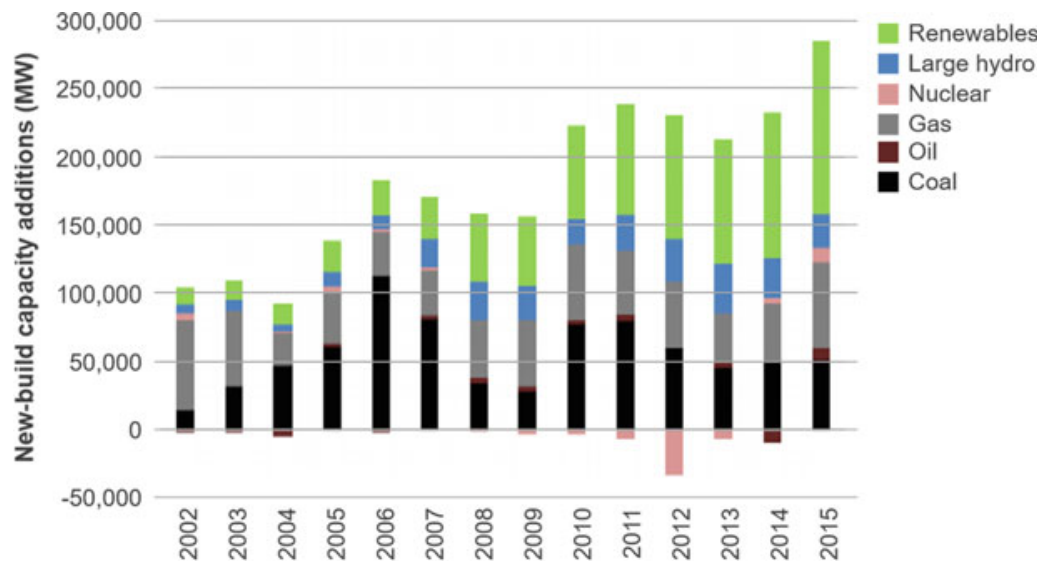


Fig. 18 Swanson's Lawlithium-ion EV battery experience curve compared with solar PV experience curve

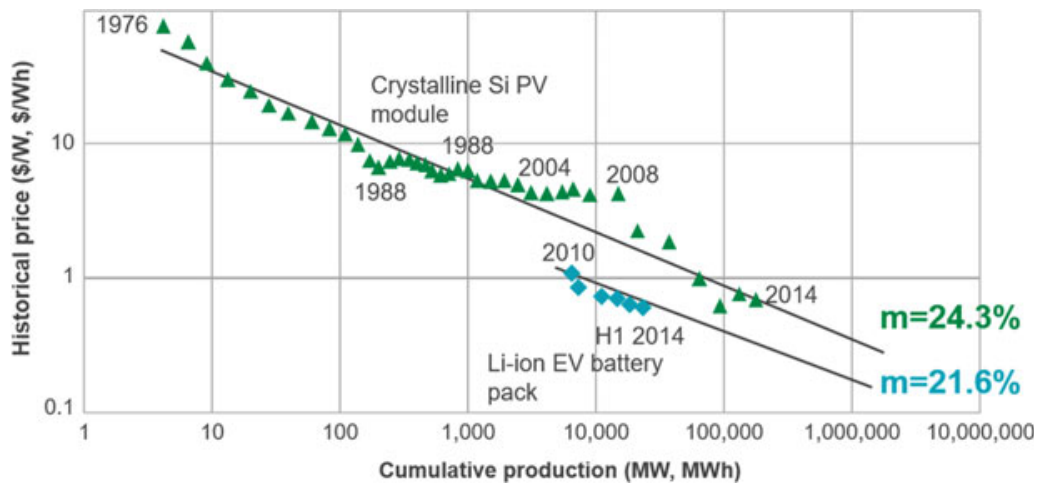

Box 5: From quantity to quality: Digitalisation and the Internet of things

Electrification, digitalisation and the Internet of things are increasingly central to high-added value economic activity. In many countries, the growing importance of electricity as an energy carrier has occurred alongside a shift from industrial- and infrastructure-driven growth to an economy driven by services.

Decoupling electricity-based services from emissions will only be possible with enhanced system flexibility, enabling a range of intermittent and dispatchable low-carbon power to replace traditional fossil fuel base load generation, without compromising security of supply. Battery storage - whether stationary or in vehicles -will clearly be an important component in enabling such flexibility.

But there is hope that the digitalisation of the energy sector and the Internet of things will unlock huge efficiency opportunities, while simultaneously enhancing the quality of energy services. DeepMind has already proven the capacity for machine learning to find unforeseen efficiency gains in a Google data centre and is now working with National Grid in the UK on a pilot project.

Within the smart energy household the idea is that devices and appliances connect to the Internet via smart meters. These appliances and devices can provide more services to the consumer while also responding to signals to reduce demand, providing balancing and flexibility on the demand side. An example is the Nest self-learning thermostat, which optimises heating and cooling of homes and businesses to conserve energy.

In the UK the Electricity Networks Strategy Group foresees the smart, digital grid becoming the "enabler for a radical departure from the operation of the current power system, with extensive balancing on the demand side". By 2020, nearly 800 million smart meters are expected to be installed globally. In China in 2015, 447 million smart meters had been installed.

Commercial application of demand management is already bearing fruit in some countries. But in all likelihood the scale of the opportunity will only be revealed with advances in machine learning and innovations in the devices and the systems that integrate them in the home or office.

Cheaper electricity storage will facilitate new energy choices and reshape energy governance. The declining cost of EV batteries is enabling cheaper stationary battery storage, creating a virtuous circle of electrified transport supplied by renewables and storage. Excess EV battery production capacity is resulting in manufacturers 


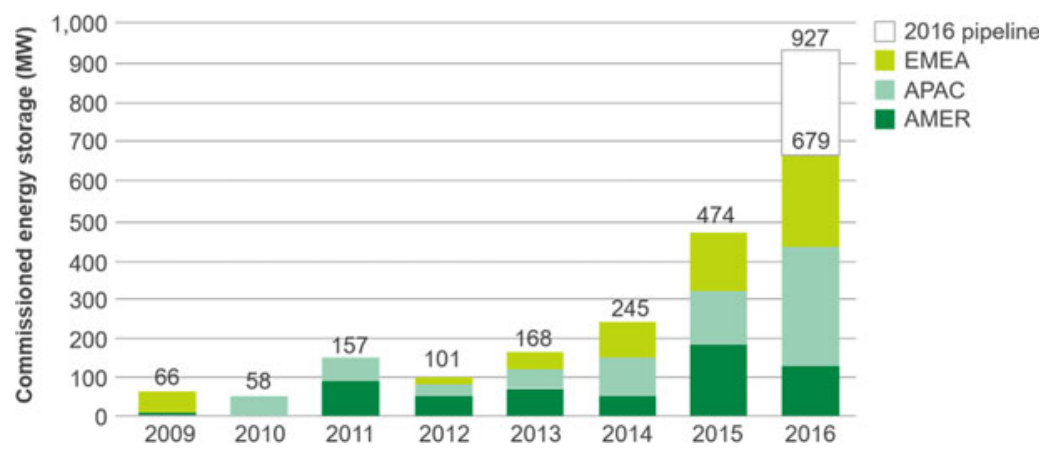

Fig. 19 Global commissioned energy storage by region, 2009-16 (MW). Note EMEA = Europe, the Middle East and Africa; APAC $=$ Asia-Pacific; AMER $=$ the Americas

selling new lithium-ion batteries into the stationary storage market at low prices. In 2016, lithium-ion $\mathrm{EV}$ batteries provided $90 \%$ of utility-scale solar photovoltaic stationary storage, with almost $1 \mathrm{GWh}$ of lithium-ion storage commissioned or in pipeline. Energy company Total invested $\$ 2.5$ billion in the battery manufacturer Saft in 2016 and the solar company SunPower. In late 2016, Bloomberg New Energy Finance forecast that EV battery manufacturing learning rates of around $19 \%$ can be expected in the future, with prices falling to $\$ 109 / \mathrm{kWh}$ by 2025 and $\$ 73 / \mathrm{kWh}$ by 2030 .

\section{Box 6: Cooperation in grid infrastruc- ture planning and capacity allocation}

Meeting the forecast growth in global electricity demand is expected to require a vast expansion of the use of renewable energy, much of it from variable sources, such as wind and solar.

While decentralised renewably generated electricity and local use is expected to be a key feature of decarbonised energy in most countries, seasonal variations in many parts of the world will lead to the need for huge storage capabilities, as well as large-scale transfer of electricity across continental distances. Greater transmission of electricity between regions is likely, therefore, to be critical.

There are currently around 12 proposals for regional grids, with interconnection capacity likely to double by 2025 (Fig. 20). Electricity network expansion, interconnection and cooperation will be a key consideration of the Belt and Road Initiative. Regional expansion of electricity grids raises important questions of investment security, infrastructural lock-in and the dangers of stranded assets.

Trade agreements and regionally coordinated planning of generation and storage capacity will be required to minimise investment risk within these large-scale infrastructure projects. Further, regionally coordinated dispatch of storage and generation, in response to varying demand patterns, will require new agencies to govern efficient operation of power markets, alongside national power market reforms and harmonisation between regional neighbours. One such example is the EU's Capacity Allocation and Congestion Management regulations to ensure effective cooperation between grid operators, power exchanges and regulators between the $28 \mathrm{EU}$ member states (Fig. 21).

The transformation and expansion of the electricity sector raises an important dilemma - the institutional home for renewable energy and grid governance remains unclear. The International Renewable Energy Agency (IRENA) was established as an intergovernmental organisation in 2009 , in order to increase 
Fig. 20 Growth in

high-voltage interconnection capacity

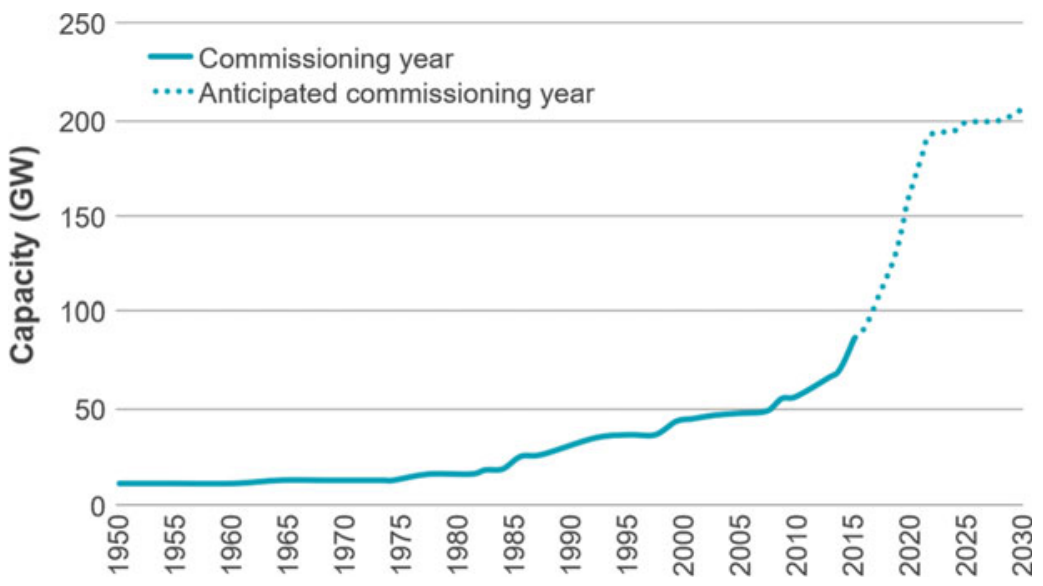

Fig. 21 Regional interconnector capacity planned and commissioned in 2030. Note MENA = Middle East and North Africa

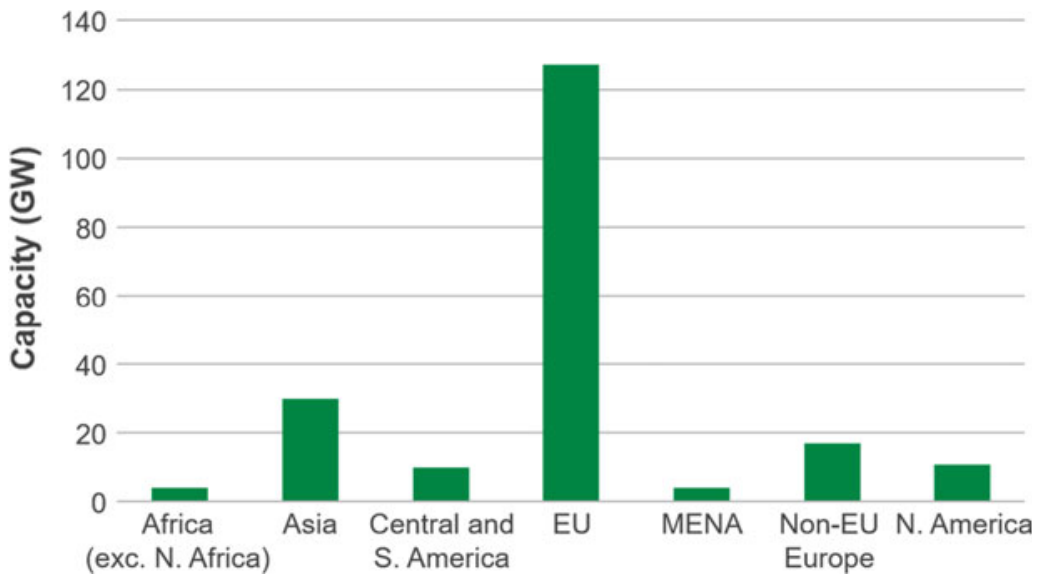

the uptake of renewable energy worldwide and address some of the challenges outlined in this section. The German government led a coalition of the willing in designing IRENA's mission. Recognising that existing energy institutions had placed more emphasis on fossil fuels, IRENA seeks to be a global voice and knowledge source for renewables, providing policy advice and serving as a network hub for member states. It is open to all UN members, lending it a high degree of legitimacy, and members have equal weight in decision-making. However, its authority and technical capacity still lags someway behind that of traditional energy governance mechanisms, such as the IEA and policy processes like those of the G20. 


\subsection{New Critical Commodities for Low-Carbon Energy Transition}

With sales of battery electric vehicles (BEVs) and plug-in hybrids expected to top 2 million per year by 2020 , there are growing concerns as to how markets and supply chains will respond to increased demand for EV critical metals such as lithium, cobalt, nickel and manganese. As these materials are difficult to replace with substitutes, governments are keen to safeguard against supply shortages. While no physical scarcity currently exists, supply risks are associated with the concentration of resources within a handful of countries and regions. Figure 22 illustrates the distribution of these materials.

Imminent low-carbon critical metal supply constraints are unlikely. This is supported by several studies showing that lithium supply may be less problematic than previously thought. However, before 2030 and the commercialisation of substitute technologies, such as lithium sulphur, which is cobalt-free and has significantly reduced lithium content, price volatility and supply chain bottlenecks could appear after 2025. Most investment in the battery sector in the past five years has poured into the major lithium-ion manufacturers. Around 100 companies are currently competing for investment in the advanced battery space, each receiving $\$ 5$ million per year on average. Larger scale investment is required to bring forward the point at which clear winners emerge and commercialisation of next-generation battery technology is achieved. Increased financial support for the U. S.-China Clean Energy Research Center and Mission Innovation could, for example, help achieve this goal.

Although supply constraints are unlikely, for EVs to achieve price parity with internal combustion engine vehicles, the aggregate cost of all materials in lithium-ion batteries needs to decline. This is especially true given price parity is estimated at $\$ 100 / \mathrm{kWh}$ and material input costs are currently around $\$ 100 / \mathrm{kWh}$. Action to alleviate potential supply constraints will have the joint effect of reducing material input costs. To this end, international cooperation to promote open data on critical metals and minerals reserves

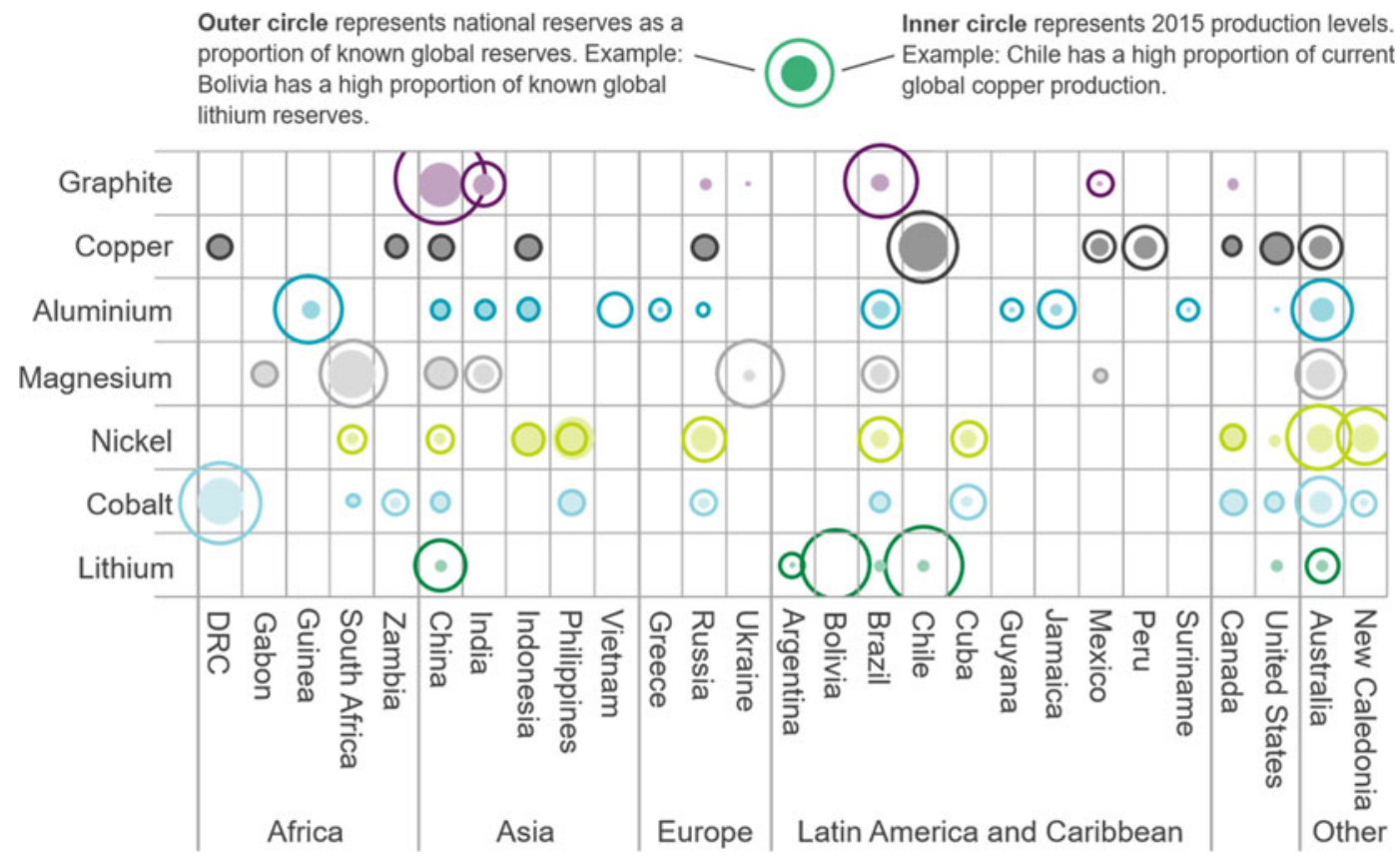

Fig. 22 Production and reserves of critical materials for lithium-ion batteries in selected countries, 2015 
and trade, alongside the mapping of in-use stocks of materials to enhance recycling collection rates, is surely a win-win.

\section{Box 7: The circular economy and resource efficiency}

China is, and will continue to be, a resource-reliant economy: as the pace of economic growth slows, demand for materials is set to continue growing. Globally, resource consumption is expected to more than double by 2050 , while resource efficiency could save the global economy $\$ 2.9$ trillion per year by 2030 .

It is possible to determine the per capita income level at which per capita demand for a particular material saturates. Across the UK, USA, Germany and Japan, apparent domestic consumption of steel saturates around $0.5-0.8$ tonnes per capita, once an income threshold of $\$ 1,200$ GDP/capita is reached.

As saturation effects kick in and economies establish a stock of primary materials in physical infrastructure and consumer goods, the circular economy can provide a means to further decouple materials demand from GDP. A circular economy is one in which the stock of materials within the economy is reused, remanufactured or repurposed as secondary materials, reducing the demand for primary material production and extraction. Globally, the circular economy is central to the next wave of energy and resource productivity enhancement. This is especially true for China, which produces $46 \%$ of global aluminium, $50 \%$ of steel and $60 \%$ of the world's cement.

Globally, iron and steel production accounts for $10 \%$ of total energy demand. Primary production of steel requires vast amounts of coking coal. Production of secondary steel, in electric arc furnaces from in-use stocks that have come to the end of their life, accounts for around 29\% of steel production. Secondary steel saves $740 \mathrm{~kg}$ of coal, $1,400 \mathrm{~kg}$ of iron ore and $120 \mathrm{~kg}$ of limestone for every tonne produced. Ensuring there is an optimal mix between primary and secondary production will be essential as China and other countries decouple energy and resource consumption from economic growth.

\section{Linear Economy}

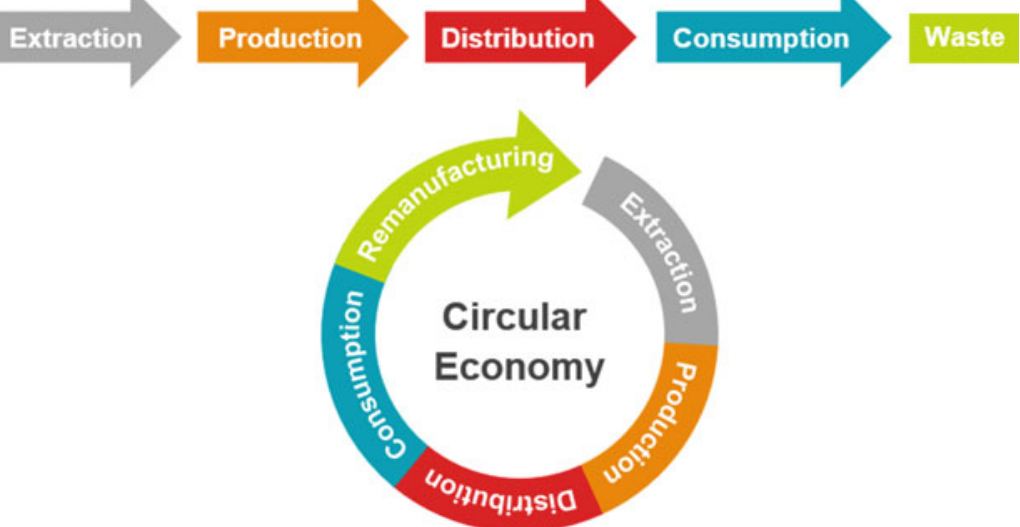




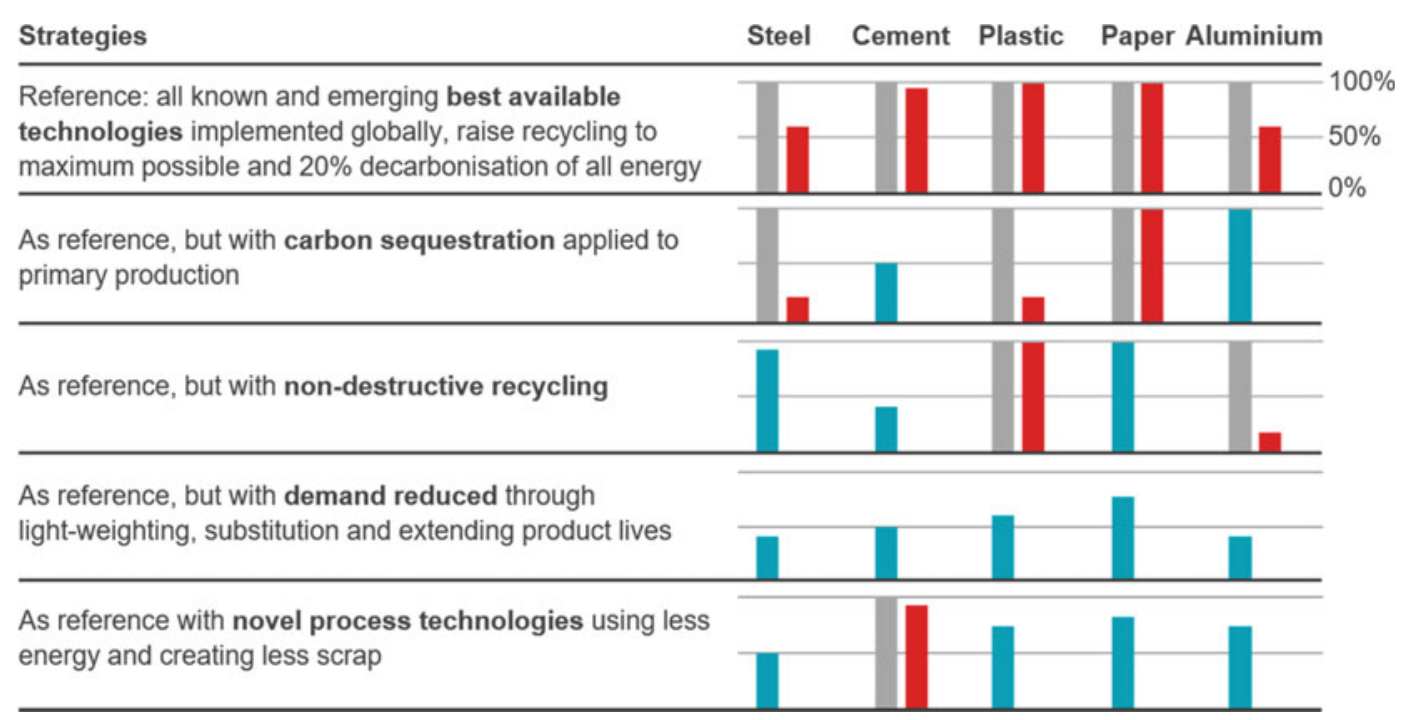

Fig. 23 Predicted 2050 emissions for the five key materials under various future strategies. Note The blue bar shows how extensively the strategy must be implemented to reach the target set by the Intergovernmental
Panel on Climate Change. If $100 \%$ implementation is insufficient, the red bar shows the excess emissions relative to the target
Capturing the benefits of the circular economy at the global scale is no easy task. While many of the technologies already exist to use previously wasted materials, standards and regulatory barriers often prevent progress. In 2008, China passed the Circular Economy Promotion Law, while in 2015 the European Commission adopted a Circular Economy Action Plan. At the international level, focus could be directed at cooperation between jurisdictions on reducing non-tariff barriers and growing the markets for circular products and services, investment and export opportunities. This could be achieved through greater engagement with the G7 Alliance on Resource Efficiency, a knowledge-sharing forum formed in 2015 (Fig. 23).

\subsection{Changing Political Dynamics for Petroleum Producers}

The emergence of new technologies like renewables, battery storage and EVs is not confined to the electricity sector. As Fig. 24 illustrates, the emergence of horizontal drilling techniques and the expansion of the number of rigs used to exploit shale oil has reversed US oil production. The US shale industry can now respond quickly to changes in the oil price. Project execution times have fallen and shale companies have cut costs, enabling them to survive in low oil price environments. Advances in horizontal drilling technology and fracturing processes, as well as huge cost reductions in extraction, have brought about a structural change in oil markets. This has undermined the ability of conventional producers to use production targets to influence oil prices (Fig. 25). 


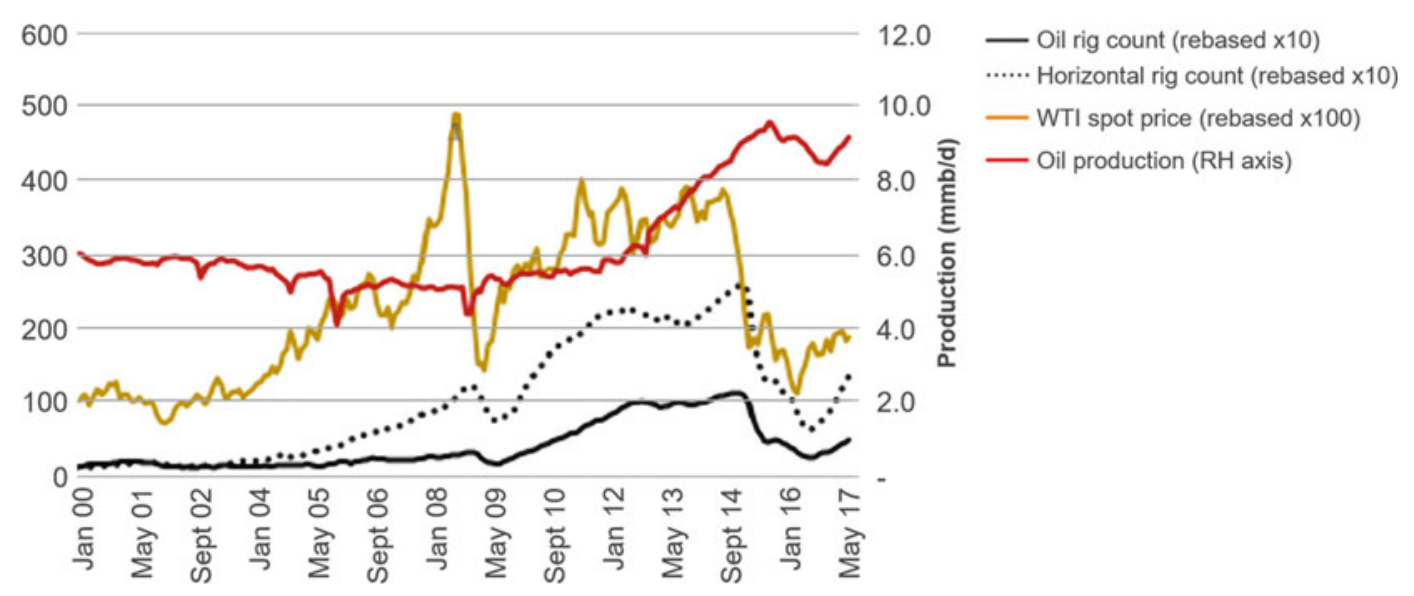

Fig. 24 Oil production in the USA in response to shale oil Source Chatham House analysis of EIA and Baker Hughes data
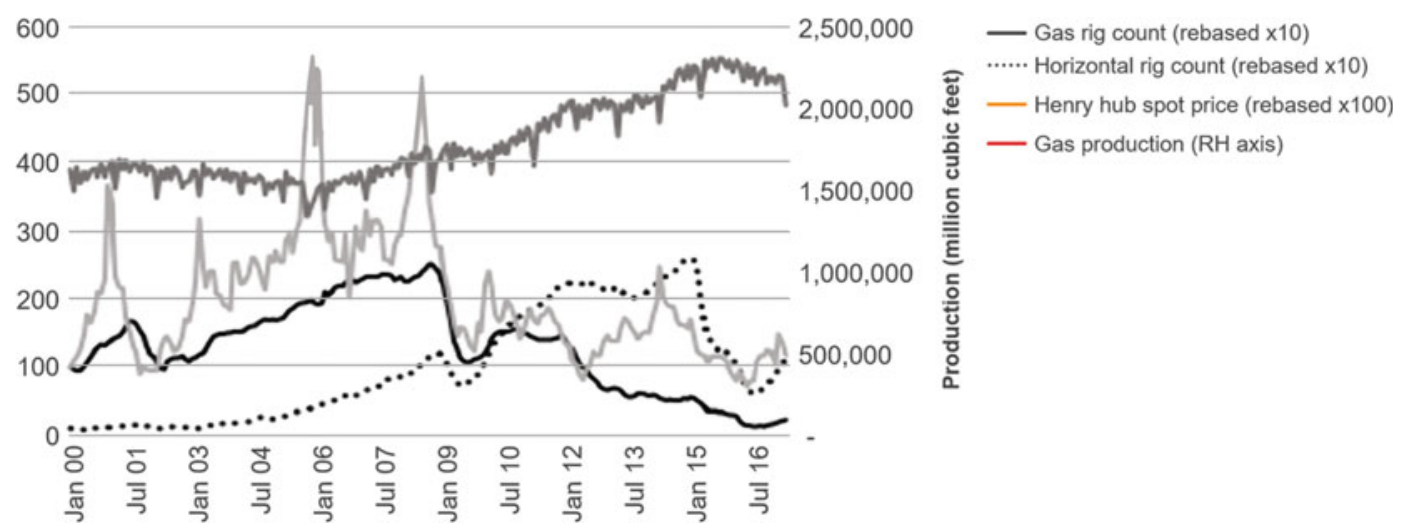

Fig. 25 Gas production in the USA in response to shale gas. Source Chatham House analysis of EIA and Baker Hughes data

Combined with the fast-growing EV sector, this shift presents major challenges to traditionally oil-led energy cooperation and governance. As Fig. 26 illustrates, transition to EVs is likely to displace at least $2 \%$ of current oil demand within 10 years, and more than $14 \%$ by 2040 . EV transition and the associated displacement of oil demand may occur faster than currently anticipated, amplifying the shift of energy governance away from oil-led cooperation. Further technological innovation would be required to displace oil from aviation and maritime, as well as petrochemicals. As global oil demand peaks (potentially as soon as 2020), plateaus and declines, the focus on oil-led energy cooperation and governance may start to shift elsewhere.

At the same time, with control over accessible conventional oil resources largely in the hands of national oil companies (NOCs) and their governments, independent oil companies (IOCs) are struggling to find viable business models or public acceptance for exploration and production projects in more geologically or politically challenging areas, such as deep water or the Arctic. This is reflected in 2017 planned expenditure, with falls of $7 \%$ and $15 \%$ for European and US IOCs respectively, while NOCs plan to increase spending by $9 \%$. Further, after falling 
Fig. 26 Crude oil displacement from electric vehicle sales. Source Chatham House analysis

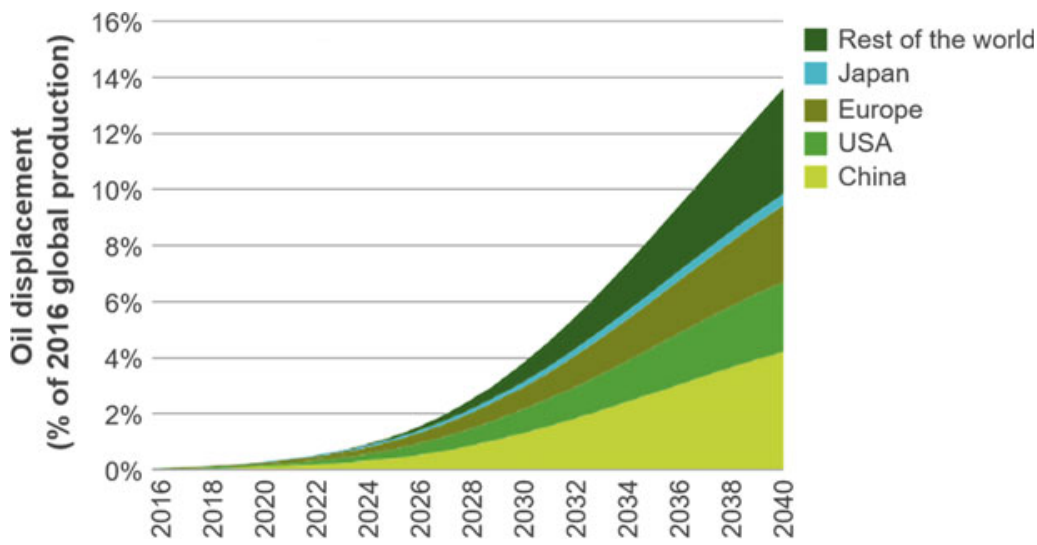

$34 \%$ in 2016, offshore spending is expected to decline by an additional 20-25\% in 2017 and floating rigs to fall from 133 in 2016 to 120 in 2017.

In line with the trend of switching from coal to gas (see Box 7) and the electrification of transport, IOCs are increasingly switching their focus to natural gas. Gas production in the second quarter of 2016 by Shell, BP and ExxonMobil, as a share of total production, stood at $50 \%, 47 \%$ and $41 \%$ respectively (Fig. 27). Natural gas could deliver lower emissions relative to coal; however, the climate impact will depend on managing methane leakage. Methane (CH4) accelerates climate change and has a greater global warming potential than $\mathrm{CO}_{2}$ over a short time horizon. Leakage rates of $1.5 \%$ from the production of natural gas increase the climate impact of natural gas by $50 \%$. One recent study shows leakage rates at gas power stations and refineries are much higher than previously thought, up to 120 and 90 times greater respectively.

For producer countries, lower oil prices have led to a reassessment of the role of hydrocarbons in their economies, as budgetary pressures increase in line with indebtedness and macroeconomic volatility. As the 2016 analysis by the International Monetary Fund shows in Fig. 28, government revenues of the countries in the Cooperation Council for the Arab States of the Gulf have rapidly declined with the oil price. Saudi Arabia's revenues fell by more than $\$ 100$ billion and it borrowed $\$ 17.5$ billion to finance its budget. Saudi Arabia has ramped up its efforts to diversify its domestic energy mix, issuing tenders for solar and wind energy investment worth between $\$ 30$ and 50 billion.

At the same time, lower oil prices are giving fiscal breathing space for countries that provide consumption subsidies for their citizens or industries. This in turn may affect the willingness of these countries to subsidise fossil fuel consumption, should higher prices return. In the OECD, fossil fuel subsidies stood at $\$ 51$ billion, or $\$ 784$ per person, in 2013. In 2014, global fossil fuel consumption subsidies stood at $\$ 493$ billion, a reduction of $\$ 39$ billion year-on-year, with oil subsidies representing more than half of all consumption subsidies. While consumption subsidies have fallen in recent years, fossil fuel consumption has been supported over the long term. Between 2003 and 2015 the consumption weighted mean net tax on petrol fell by $13.3 \%$ across 157 countries. Of these 157 countries, 84 either reduced consumption subsidies or increased petrol taxes. But as consumption has shifted towards nations that have maintained subsidies or lowered petrol taxes, subsidy reforms have been undermined at a global level. Following the agreement by the G20 in September 2009 to phase out inefficient fossil fuel subsidies, as of mid-2015 the unweighted mean net tax was unchanged across the 20 states. However, this commitment has not been reaffirmed at the latest G20 meetings (Fig. 29). 
Fig. 27 IOC natural gas production and as a share of total production
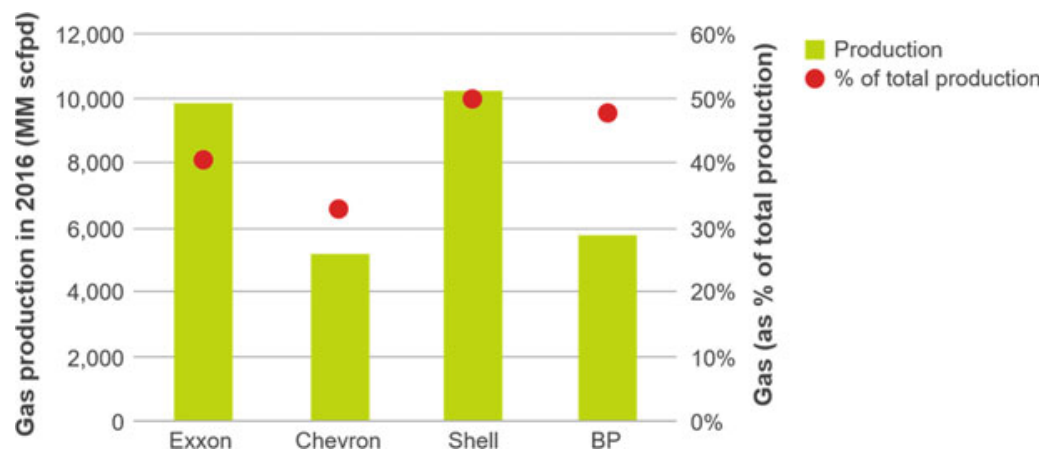

Fig. 28 GCC government revenue and expenditure (per cent of non-oil GDP, weighted average)

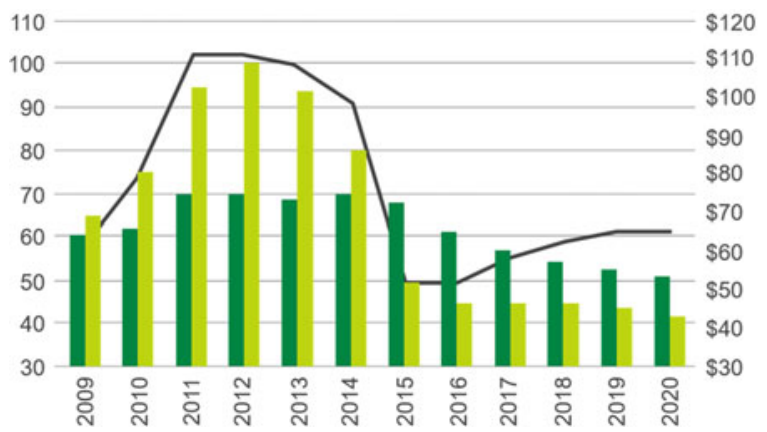

GCC total expenditure GCC revenue - Brent price (\$, RHS)
Fig. 29 Estimates for global fossil fuel consumption subsidies and subsidies for renewables

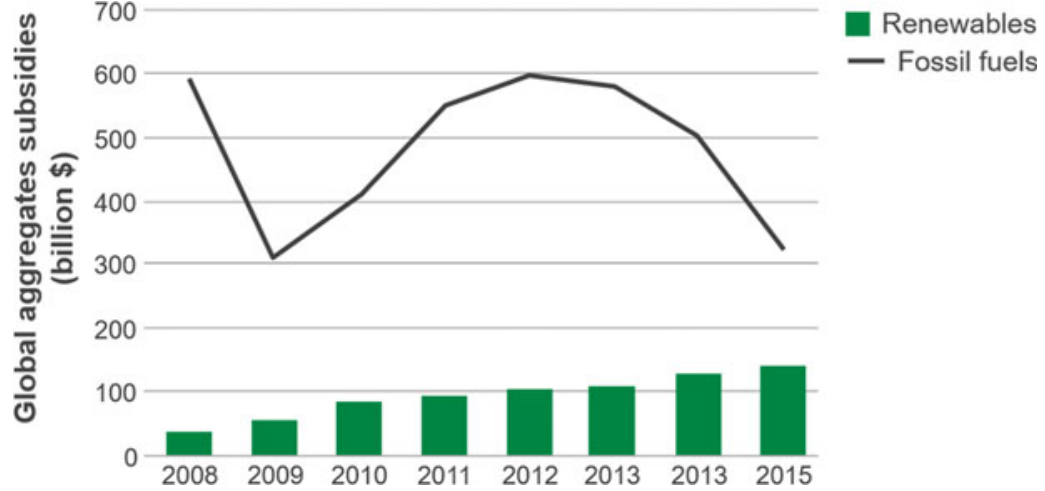

Box 8: Imperative areas for cooperative action

Figure 30 shows a set of imperatives for a low-carbon, energy-secure transition that responds to the main trends reshaping the global energy system and driving the energy transition. We also highlight examples of specific actions the international community could pursue to help deliver on these imperatives. 


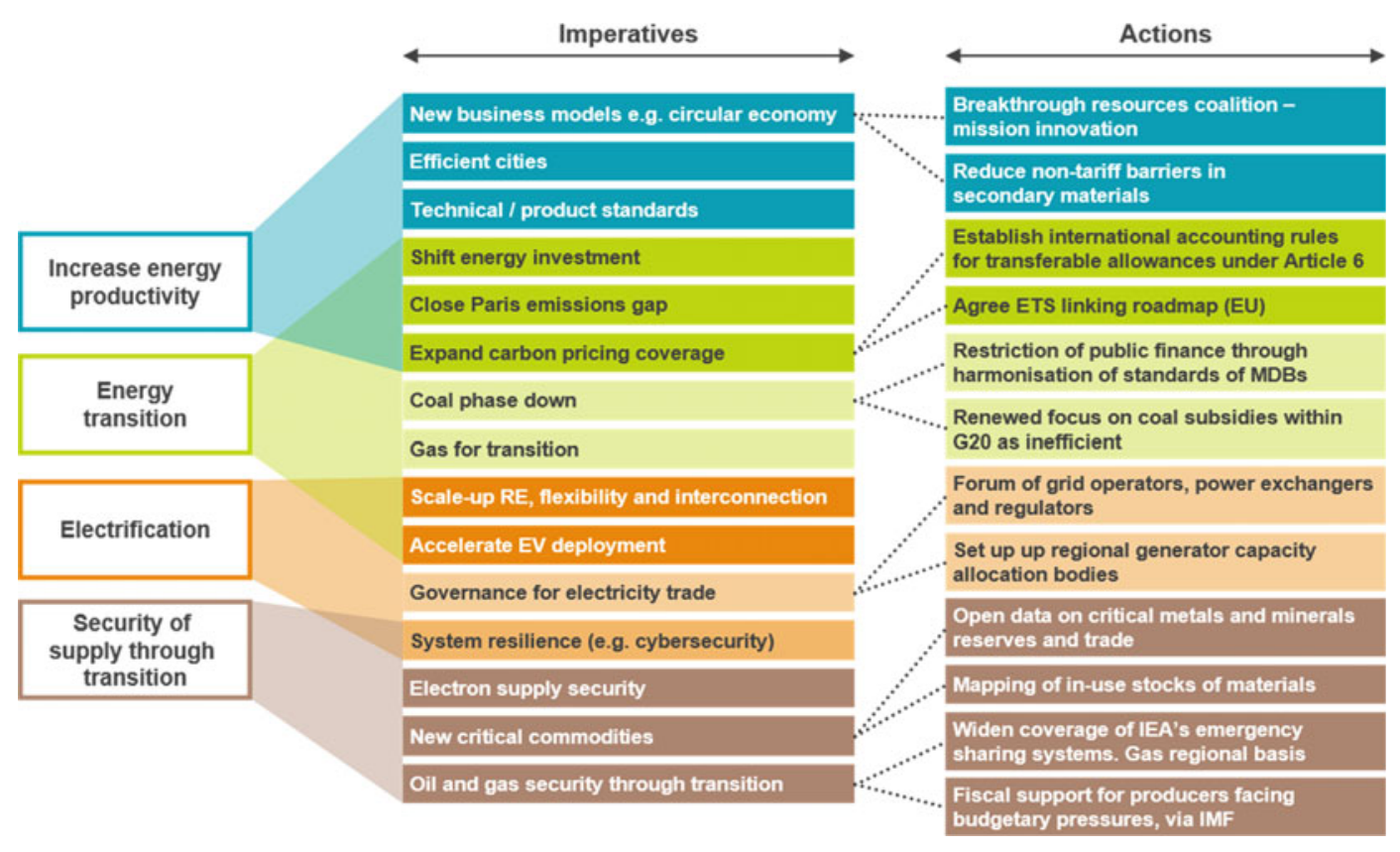

Fig. 30 Imperatives for a low-carbon, energy-secure transition, alongside examples of actions that could enable those imperatives to be met. Note Article $6=$ Article 6 of the Paris Agreement allows countries to cooperate with each other when implementing their nationally

\section{Five Pillars of International Cooperation on Energy}

There are five pillars of global governance and international cooperation within the energy sector: trade, investment, innovation, security of supply, and cross-border externality. These pillars are critical when analysing the effectiveness of agreements and actions taken at the international level.

\subsection{Trade}

Despite the nascent transformation of the energy sector, energy trade remains dominated by fossil fuels, with Chinese demand a key market driver. In the past 15 years, traded volumes of oil have increased $14 \%$, coal has more than doubled, and natural gas and liquefied natural gas (LNG) have increased by almost $60 \%$. determined contributions by using market-based mechanisms; $\quad \mathrm{ETS}=\mathrm{EU}$ Emissions Trading System; IEA = International Energy Agency; IMF = International Monetary Fund

Reflecting the broad trend of declining demand among OECD countries and strong growth among emerging economies, China became the world's second largest crude oil importer in 2009 and is set to surpass the USA to become the largest. India is now the third biggest importer, although with imports $42 \%$ lower than China. In the context of the US tight oil revolution, the centre of gravity of international oil trade has shifted east, with non-IEA consumer countries accounting for a growing share of demand, and non-OPEC countries providing a growing share of supply. Net importing countries, including China, still view high dependency on oil from the Gulf states of the Middle East as an energy security vulnerability.

In 2016, global trade in LNG increased at its fastest rate in five years as new facilities in the USA and Australia began to challenge Qatar's market dominance. Between 2009 and 2015 imports of LNG grew $30.5 \%$ globally, with the Asia-Pacific region and China representing 
$71.1 \%$ and $8.1 \%$ respectively of the 245 million tonnes of demand in 2015. Global demand growth of $72.3 \%$ by 2030 , relative to 2015 , is expected. The world's biggest LNG plant is in Australia, having cost $\$ 200$ billion. US exports have been driven by the Sabine Pass terminal in Louisiana, owned and operated by Cheniere Energy, which ships LNG to markets such as Japan and Chile.

These new LNG trade flows are beginning to draw new import-export interdependencies, resulting in new bilateral trade agreements such as the May 2017 agreement between the USA and China. The bilateral agreement aims to consolidate the export of US LNG to China into long-term trade contracts, which accounted for 7\% of China's imports in March 2017.

A clearer understanding of coal markets and the links between coal producing and consuming countries is needed to avoid potential roadblocks to implementation of the Paris Agreement, and to address potential cross-border financial exposure to coal investments.

The market for traded coal has grown rapidly since the turn of the century, doubling in weight to around 1.4 billion tonnes and increasing fourfold in value to almost $\$ 100$ billion. Coal trade has also increased as a share of global coal consumption, rising from $18.5 \%$ in 2000 to $23.5 \%$ in 2014. Today, six coal superpowers dominate trade: Australia and Indonesia account for around $60 \%$ of exports while China, India, Japan and South Korea provide $60 \%$ of imports. This trade is underpinned by foreign direct investment flows into coal mining, infrastructure and generation capacity within the Asia-Pacific region.

Trade is a common area for international cooperation, because countries can mutually benefit from deeper trade, which facilitates access to cheaper goods and new markets. However, the political economy of trade integration is not straightforward because although benefits may occur in the economy, trade can create winners and losers at the sectoral level; governments may also wish to protect certain sectors of the economy for industrial strategic reasons. Governance arrangements are therefore needed to set the rules for how countries trade with one another-in particular to mitigate tit-for-tat barriers and provide mechanisms for negotiation and dispute resolution. At the multilateral level, these rules are set by the World Trade Organization (WTO), although many regional and bilateral trade agreements exist between countries.

Trade in energy (as a natural resource) falls largely outside the WTO's scope due to sovereignty considerations and other factors. Some regional agreements have tried to bridge this gap for energy, notably the Energy Charter Treaty and the energy chapter of the North American Free Trade Agreement. For processed products and manufactures, however, normal WTO rules apply - these energy-related trades have become a political battleground.

While provisions in the General Agreement on Tariffs and Trade (GATT) do not include natural resources, a service relating to natural resources (exploration, exploitation, technical testing and transport) is subject to GATT regulations unless provided by government authorities. This had led to calls for a more coherent framework, specifying which rules apply to which resource type, which qualifications are needed for a resource to be considered a good or a service, and including important issues for oil and gas, such as investment protection.

With the rising importance of renewable energy, both for energy supply and as an important area for manufacturing competitiveness, there has been rising scrutiny over tariffs on low-carbon and environmental goods, which raise their costs and slow down diffusion rates. Proposals to eliminate these tariffs have been made at the WTO by countries accounting for $86 \%$ of global trade in these goods. Yet at the same time, some of the same countries have become embroiled in serious trade disputes over specific low-carbon products in which there is particularly fierce competition. It is estimated that roughly $14 \%$ of WTO disputes since 2010 relate at least in part to renewable energy. Many of these disputes concern renewable energy subsidies and local content requirements, which countries and states have used to support 
domestic industrial sectors; there are also several disputes over the pricing of low-carbon exports such as solar panels, which have led to increases in import duties. These disputes have raised prices, damaging the deployment of renewable energy sources.

The trade in electricity is a special case. Electricity is not traded globally, unlike most other products and services that are subject to international competition. Furthermore, in its classification by the WTO, electricity is treated as both a good and a service and is therefore subject to different tariffs and rules. In addition to the interconnectors needed for the flow of electricity across borders, there is the issue of market coupling, i.e. arrangements that allow efficient trading of energy (in this case electricity) between markets. These tend to be managed under bilateral and regional arrangements, the most extensive being those in the EU and with its neighbours.

Increasing trade in electricity is driving a growing number of agreements on electricity trade via interconnectors. As well as governing operation, agreements can also mitigate the investment risks associated with large infrastructure projects. For example, in 2016, the North Sea countries of Belgium, Denmark, France, Germany, Ireland, Luxembourg, the Netherlands, Norway and Sweden signed an energy cooperation agreement to build missing interconnectors and allow greater trading of energy, while further integrating their respective national energy markets. In July 2015, the EU adopted trading regulations on Capacity Allocation and Congestion Management. The regulations were designed to integrate more renewables into the grid and enable effective cooperation regionally between grid operators, power exchanges and regulators of the $28 \mathrm{EU}$ member states, saving EU consumers $€ 2.5-4$ billion.

Growing deployment of new technologiesespecially batteries - is increasing trade in critical raw materials such as lithium, cobalt, polysilicon and rare earth elements. Goldman Sachs estimates that for every $1 \%$ increase in the penetration of plug-in battery electric vehicles, lithium carbonate equivalent (LCE) demand will increase by 70,000 tonnes per year, equating to around half the current annual demand for LCE.

However, compared to energy commodities, international metals and minerals markets are relatively ungoverned: transparency is poor and when cooperation occurs, it has often taken the form of collusion; markets are also regularly disrupted by unilateral export controls.

\subsection{Investment}

Finance and investment regimes are fast becoming new frontiers of energy governance, driven in part by efforts to shift capital from high-carbon to low-carbon energy sources, as well as concerns over disruption to the business models of utilities. More than $60 \%$ of global emissions are caused by investments in, and operation of, long-life infrastructure, which have the potential to lock in emissions far into the future. The IEA $2^{\circ} \mathrm{C}$ pathway requires a tripling of annual investment in low-carbon power infrastructure by 2035, and an eightfold increase in energy efficiency investments. Today, shadow carbon prices are already used as investment screening tools by many oil majors, and attention is growing among financial regulators and policymakers.

Expansion of shadow carbon prices and greater investment screening within the fossil fuel sectors have become commonplace. There is growing scrutiny from institutional investors, particularly regarding so-called transition risk to assets and business models arising from decarbonisation of the economy. A major game-changer is the G20 Financial Stability Board's Task Force on Climate-related Financial Disclosures (TCFD), which has published recommendations on climate disclosure. Recently, investors voted for ExxonMobil to publish annual assessments of the impacts of a low oil demand scenario under a $2^{\circ} \mathrm{C}$ target. The first step under the TCFDs implementation path is illustrated in Fig. 31. Coordination among financial policymakers and regulatory authorities will be necessary if climate-related financial disclosures are to encourage portfolio rebalancing. 


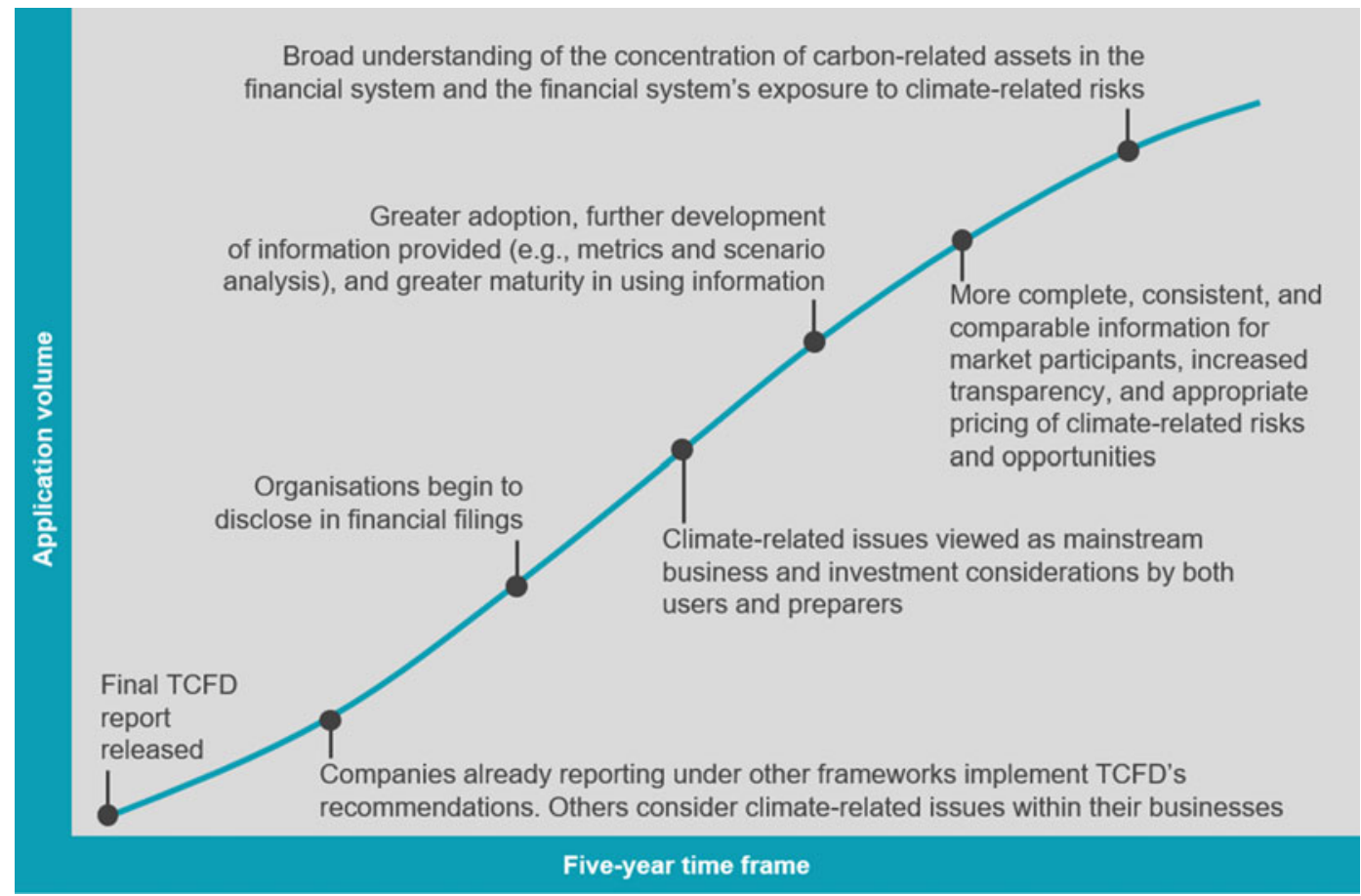

Fig. 31 TCFD implementation path of recommendations on climate-related financial disclosures

Attention is also shifting to the role of development finance institutions and multilateral development banks, including the Asian Infrastructure Investment Bank (AIIB) and New Development Bank, as capital providers. Although most institutions are doing something to mainstream climate change into their portfolios and operations, progress has been patchy and uneven. There is a lack of common frameworks to evaluate the social, economic and sustainability of projects across multilateral development banks.

One of the clearest governance challenges revolves around financial flows to coal mining and coal-fired power generation. The implementation of multilateral guarantees continues to come under scrutiny from civil society; the International Finance Corporation, for instance, has allegedly financed 41 new coal projects since the World Bank commitment in 2013. The AIIB has stated that it would not invest in coal but is at risk of relenting on this commitment following heavy lobbying by coal exporting countries such as Australia. Meanwhile Japan, China and South
Korea account for most of the G20's \$24 billion in export-import bank and development finance packages that support coal.

The IEA $2^{\circ} \mathrm{C}$ pathway will also require the stranding of high-carbon assets, which cannot be operated fully over their lifetime to respect the remaining carbon budget. Although there is much bilateral cooperation on energy infrastructure investment, there is a lack of rules or standards for aligning investments with low-carbon priorities. There may be opportunities for the G20 to address this in the first instance, building both on its global infrastructure initiative and the TCFD.

Hydrocarbon investments commonly face significant political risks, by nature of the countries targeted and the complexities of resource curse dynamics and the long timescales over which assets operate and recoup costs. Cooperative approaches have emerged to help manage these risks, through pooling, dispute resolution and norm setting, in particular the World Bank's Multilateral Investment Guarantee Agency and the Energy Charter Treaty. 


\subsection{Innovation}

Despite rapid progress on some technologies such as solar photovoltaic, wind power, LED lightbulbs and batteries, the pace of deployment is too slow to meet climate goals, according to the IEA. Chatham House research has found that innovations within the energy sector take 20-30 years to penetrate the mass market. Accelerating the rate at which future innovations reach the mass market could be achieved by a publicly backed energy patent pool, enabling market disrupters to access patents.

Mission Innovation and the Breakthrough Energy Coalition are new, significant global attempts to scale up R\&D funding and focus on the next generation of technological breakthroughs needed to achieve the Paris Agreement, such as advanced battery chemistries like metal-air. However, many key technologies are held up not by lack of research and development but by lack of policy support and investment. Reaching critical levels of deployment will require wider alignment of supply, demand and market factors. Ensuring rapid penetration of electric vehicles, autonomous driving and wireless charging, for example, requires cooperation and coherence of standards and regulations across jurisdictions.

Most energy technologies are part of complex global technology systems. Their development does not often follow a linear logic or evolve within the boundaries of individual economic sectors. Many breakthrough innovations occur when different fields interact. For example, innovation in solar photovoltaic technologies has benefited from developments in consumer and industrial electronics, and advances in concentrated solar power derive from aerospace and satellite technologies.

The IEA's Tracking Clean Energy Progress 2017 report shows that many necessary technologies are held up not by lack of innovation, but by lack of policy support and investment. It also reveals where some of the most urgent action may be needed to accelerate technology deployment and adoption.
Most energy models anticipate large-scale application of negative emissions technologies, such as bio-energy with carbon capture and storage (BECCS) or carbon capture and use. However, there are significant uncertainties and potential trade-offs. Electrification also creates new challenges for innovation at the system level. For instance, strategies to bring down the costs of electricity storage, expansion of grid infrastructure and coordinated reforms of power markets may need to be aligned.

There is increasing interest in the potential for new business models to unlock energy and resource savings through substitution, digitalisation, sharing and reuse, among others. China and the EU both have circular economy strategies that could be used as a platform for cooperation (Fig. 32).

\subsection{Supply Security}

With instability in the Middle East unlikely to recede in the foreseeable future, and the possibility of a supply crunch from conventional resources on the horizon, security of supply remains a political priority for many importing governments. In theory, international cooperation can help manage the risks of major supply disruption by setting rules and modalities for how governments will coordinate in the event of a shock, so avoiding an all-out scramble for supply that could heighten a crisis. However, IEA members' share of energy trade is declining, leading to growing questions over the effectiveness of the IEA emergency response mechanism in the event of a serious supply shock. Key issues therefore include whether and how emerging economies can be integrated into the IEA regime, or whether regional approaches may offer more practical solutions and if this is the case, how coordination can be managed among them. Other related concerns include maritime governance, particularly around critical choke points.

Meanwhile, the growing adoption of renewable energy sources and transformation of electricity grids create new challenges of supply security. Key issues are likely to include: 

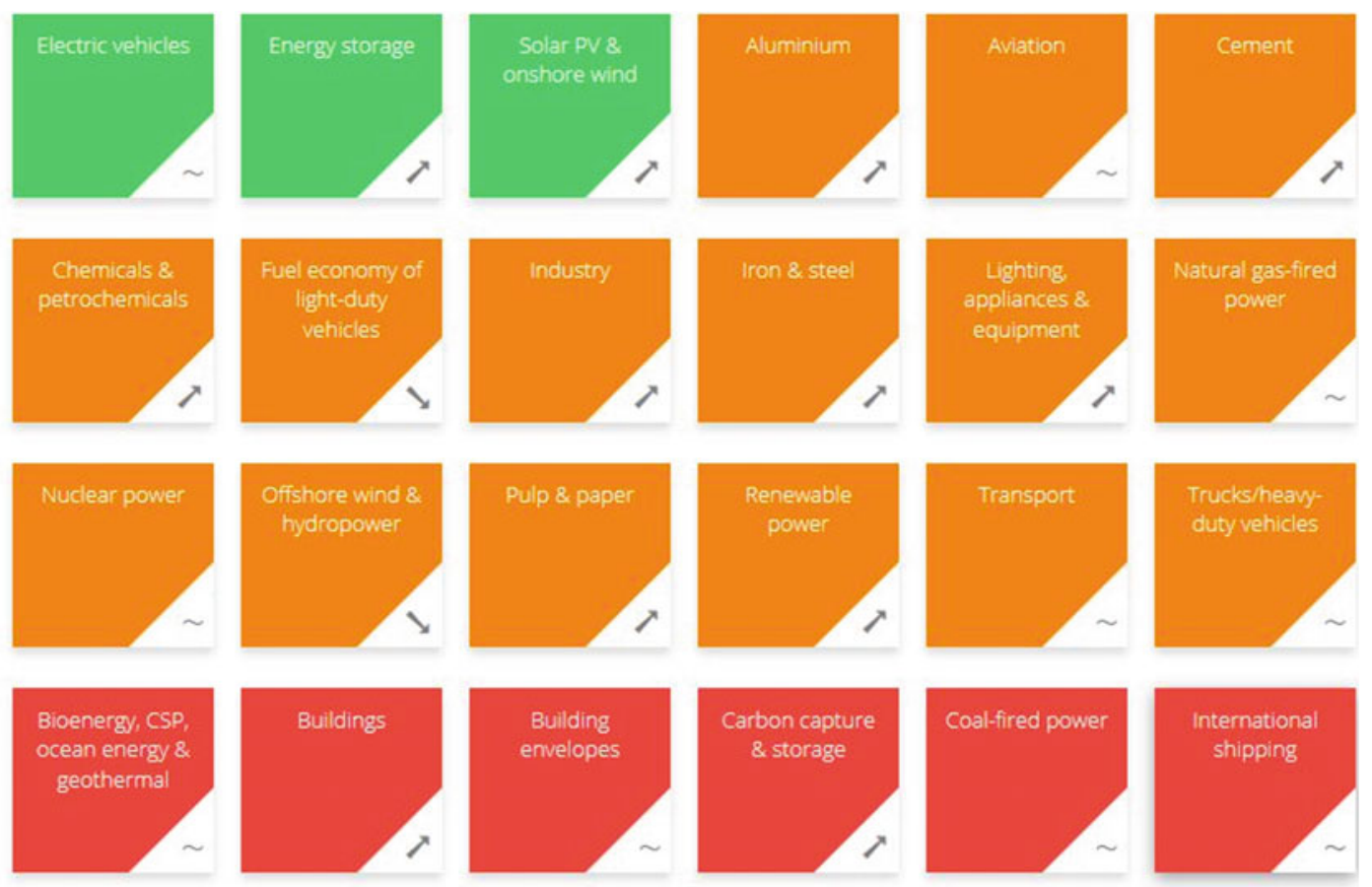

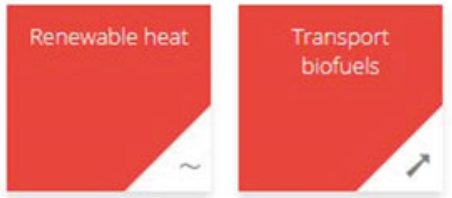

\section{Status against $2^{\circ} \mathrm{C}$ scenario targets to 2025 \\ On track, but sustained deployment \& policies required Improvement, but more efforts needed Not on track}

\section{Recent trends \\ Positive developments \\ $\sim$ Limited developments \\ $\searrow$ Negative developments}

Fig. 32 Analysis of clean technology progress. Source International Energy Agency, Tracking Clean Energy Progress 2017

1. cooperation to improve battery technology and seasonal storage investment to bring down the costs of electricity storage;

2. expansion of grid infrastructure regionally and continentally to smooth supply-demand imbalances and exploit opportunities to export electricity from regions with high renewable capacities; and

3. coordinating reforms of power markets in line with grid expansion to enable capacity markets, or equivalent market mechanisms, to provide adequate and affordable fast-reacting generators to balance intermittent renewable supply.

Due to the increasing demand for certain metal resources for low-carbon technology manufacture, the geographic concentration of resources such as lithium and cobalt in fragile regions, and the difficulty of substitution, governments and businesses are increasingly keen to safeguard against supply shortages in growing markets. 
The World Trade Organization (WTO) has been of little use in managing supply security as it is focused on avoiding import restrictions rather than avoiding export controls. Article XI of GATT 1994 requires that exports should not be subject to quantitative restrictions "other than duties, taxes or other charges"-but it does not fix a maximum level for border taxes, except for those countries which accepted them within their accession agreements (including China). Article XI has been interpreted as not prohibiting export taxes, which explains why "more than $1 / 3$ of notified export restrictions are in resource sectors, where export taxes on natural resources appear to be twice as likely as export taxes in other sectors". In recent years, several key raw material suppliers have used export controls. Indonesia has introduced a ban on exports of unprocessed ores. Vietnam has also imposed restrictions on iron ore and copper, and export taxes have recently been debated in Brazil and India. In 2012, the USA, the EU and Japan lodged a complaint with the WTO over Chinese export quotas of rare earth minerals, and the quota system was withdrawn in late 2014. There have been various proposals for voluntary avoidance of export restrictions in times of crisis or extreme price volatility, which such restrictions tend to exacerbate.

Data is also an important area for cooperation. Markets that are less transparent tend to be more prone to instability, as market participants have less confidence in fundamentals and so are more prone to erratic behaviour such as panic buying or hoarding. Governance arrangements to improve transparency and accessibility of data, in particular on stocks, in oil markets have emerged from the International Energy Forum in the form of the Joint Organisations Data Initiative - an approach that has been mirrored in soft commodity markets with the Agricultural Market Information System. As the shift from molecules to electrons continues, and energy interdependencies become increasingly linked to data-intensive electricity grids, data will become increasingly fundamental to energy cooperation and governance.

\subsection{Cross-Border Externality}

By its very nature, a cross-border externality cannot be resolved without cooperation. The text-book example of cooperation and governance to resolve a cross-border externality is the Montreal Protocol to deal with ozone-depleting gases (see Appendix). Climate change has proven more challenging, essentially because of the initial lack of readily available low-cost substitutable technologies and the greater entanglement of high-carbon (as compared to high chlorofluorocarbons, CFC) activities within economies. The politico-economic challenges of action on climate change have been eased significantly by rapid falls in low-carbon technology costs and growing awareness of the co-benefits of low-carbon policies. This facilitates an approach that allows governments to unilaterally determine national ambition based on domestic circumstances within a multilateral framework for transparency and reporting (see Appendix).

Post-Paris, there is growing momentum around cooperation on carbon pricing as a market-based mechanism to internalise the externality. Linking carbon pricing mechanisms provides a means to broaden coverage, reduce decarbonisation costs and minimise carbon leakage.

\section{Box 9: Carbon pricing}

The Energy Transitions Commission, along with many other commentators, view carbon pricing as an essential component to drive the energy transition. Around 13\% of global $\mathrm{CO}_{2}$ emissions are covered by carbon pricing in one form or another. Typical prices are around \$10/tonne. Coverage and prices are likely to rise in the coming years. By the end of 2017 it is anticipated that $30 \%$ of global emissions will fall under carbon pricing systems, with countries such as Canada ratcheting floor prices up to $\$ 25 /$ tonne or more within the next five years.

As many of the emission trading systems (ETS) have experienced low and 
unstable prices, the desired effect of stimulating changes within the energy system has been weaker than expected. However, many companies have now adopted shadow carbon prices, under the anticipation that carbon pricing would impact returns on their investments. But the weaker than expected development of ETS has led to concerns over companies dropping these screening measures. This highlights the need to ensure greater coverage, with stable, predictable and significant prices.

The lull in momentum to expand carbon pricing, either as a trading system or as a tax, has recently reversed. The Carbon Pricing Leadership Coalition (CPLC) represents 21 countries, five Canadian and US states, and almost 140 global corporations. In January 2016 the CPLC challenged global governments to double carbon pricing coverage by 2020 and double again by 2030 . Further, the Climate Leadership Council recently proposed a $\$ 40 /$ tonne carbon tax and dividend scheme in the USA, including a carbon border adjustment tax.

The pathway to the national Chinese ETS is under way. However, the uncertainty over allowance holders within China's regional ETS pilots being able to transfer to the national ETS is hampering the 2017 intended launch of the national ETS. Lack of transparent market information within the pilots has also reduced the volumes traded relative to the cap, compared to other ETS such as California.

While a global carbon market is unlikely in the short to medium term, linking existing carbon markets is generally accepted to increase the effectiveness of national markets. Considering the national ETS in China is due to commence in 2017, one significant policy consideration is the future linking to the EU or South Korean market. If carbon clubs or bilateral links to other ETS are to emerge, greater transparency within the Chinese ETS will be critical. Given the potential size of the Chinese ETS, if it fails to deliver a stable and effective carbon price, carbon trading is likely to face a considerable challenge in convincing international policymakers that continued development of carbon markets is an effective climate policy pathway.

\section{Making Global Energy Governance Fit for the Future}

Much of the current global energy governance architecture has evolved from arrangements to address oil security concerns stemming from the oil shocks of the 1970s. However, the effectiveness of these mechanisms - specifically the emergency response mechanism of the International Energy Agency (IEA) - has been gradually eroded by the shift in hydrocarbon demand from IEA member countries of the OECD to emerging economies outside of the regime.

More recently, with around two-thirds of global greenhouse gas emissions coming from the energy sector, decarbonisation has moved to the centre of the energy policy agenda. An increasingly analytical focus on low-carbon transition is evident within organisations like the IEA and with the establishment of new multilateral institutions, such as the German-led International Renewable Energy Association. Meanwhile, multilateral development banks, such as the World Bank, have scaled up their technical assistance and financial commitments for cleaner energy.

Although outside the sphere of traditional energy governance, the establishment of the United Nations Framework Convention on Climate Change in 1990 and the Paris Agreement in 2015 have had profound implications. The latter provides the pillars of a new global climate regime: a transparency framework for the measurement and reporting of emission reductions and actions; a long-term goal to reduce global greenhouse gas emissions to net zero and limit 
temperature rises to well below $2^{\circ} \mathrm{C}$; and a process of pledge and review through which governments progressively update the ambition of their nationally determined contributions every five years in order to incrementally increase collective ambition.

The strong overlap between the global climate regime objective of limiting global warming to well below $2^{\circ} \mathrm{C}$ and the challenges of managing a low-carbon, secure transition means there are opportunities to harmonise climate and energy governance. At the same time, representation in traditional energy governance institutions and mechanisms must be broadened, even as they focus on energy transition; membership beyond OECD countries is critical if the IEA is to remain a relevant institution.

\section{Box 10: IEA expansion}

One of the principal barriers to expanding IEA membership to include emerging economies has been that the International Energy Programme (IEP) treaty, which provides the legal framework for member countries, requires that signatory countries be members of the OECD. This means that expanding membership of the IEA would require treaty change. It would also require reforms to the voting rights of countries within the IEA, which currently reflect their levels of consumption in 1973; this would inevitably create winners and losers and would give an incoming producer such as China significant voting power.

One way to effectively become a member of the IEA without signing the IEP treaty would be to follow Norway's path. Norway has a separate partnership agreement with the IEA under which it acts as a full member country for all intents and purposes, although it has not signed the IEP. Such a path could potentially be available to emerging economies. This would, of course, require the emerging economies concerned to follow the same rules - including those on data sharing and emergency stock coordination - as existing member countries.

A roadmap to expansion could conceivably be agreed between the IEA and emerging economies setting out key milestones that both sides would need to reach in order for the partnership to become politically and technically feasible. These might include: (i) the IEA opening a new secretariat office in Asia to deepen its links with officials in Asian consumer countries; (ii) the IEA cooperating with China on electricity market reform pilots, providing technical support to strengthen ties at the municipal level and demonstrate its capabilities beyond the oil market; and iii) emerging economies developing the necessary technical and institutional infrastructure to meet IEA requirements in terms of information and data sharing, stock management, demand restraint and agreeing to peer review.

\subsection{Cooperation Opportunity}

Due to its leadership role among emerging economies, and its position as the world's largest energy consumer and greenhouse gas emitter, China is uniquely placed to drive global energy governance reforms.

Targeted outcome: Representative global energy governance institutions providing harmonised energy and climate public goods.

To achieve such an outcome, China could adopt two distinct strategic cooperation pathways:

(1) reform the IEA to make it more representative, effective and relevant; and

(2) harmonise global energy and climate governance to facilitate the transition to a low-carbon, energy-secure future. 


\subsection{The G20 as a Forum for Reform}

The G20 could provide a suitable forum to promote global energy governance reform. It has a track record of international organisation reform (emerging economies used it to reform the International Monetary Fund following the global financial crisis of 2008) and experience of establishing new international mechanisms, such as the Agricultural Market Information System. The G20's membership provides a balance of OECD and emerging economies, and of producers and consumers of fossil-fuel based energy. It therefore has the requisite critical mass on key transition issues such as energy consumption and production $(23 \%$ and $19 \%$ respectively), emissions (30\% of global total, double that of the USA) and energy investment (21\%).

Moreover, many aspects of the current G20 agenda are highly relevant, including the Principles for Energy Collaboration it adopted in 2014 (which included its long-running commitments to fossil fuel subsidy reform), the emergence of green finance under China's presidency in 2016, and progress on climate-related financial disclosures through the Financial Stability Board.

Sustaining a reform process through the G20 would not be without challenges. First, the G20 is an informal club of governments, without a secretariat to provide support and ensure delivery. Second, and relatedly, the G20 struggles to sustain focus as its agenda tends to shift with the priorities of successive presidencies. Consequently, any ambitious energy governance reform agenda would need to include a strategy to sustain G20 engagement.

\section{Box 11: Strengthening oil security in Asia}

Asia consumes a third of the world's oil. About two-thirds of that are imports of crude oil.

Only two ASEAN Plus Three countries (Japan and South Korea) are party to the OECD-based IEA with its emergency response mechanism and obligations to hold at least 90 days of oil imports as compulsory stocks.

Asia and ASEAN lack mechanisms to respond to supply disruptions collectively rather than competitively: major disruptions would lead to a scramble for supplies and large spikes in international oil prices. The ASEAN Petroleum Supply Agreement (APSA) supports, on a best endeavours basis, member countries experiencing a supply disruption equivalent to $10 \%$ of consumption over 30 days. These efforts may include a coordinated stock release, relying on cooperation between the state companies of the ASEAN countries. A major disruption would likely generate considerable uncertainty over how Asian governments would respond. Given APSA is currently set to expire in 2023, and global oil prices are relatively low, now is a good time to push for expansion of regional strategic oil which could calm markets if there was a disruption to supply. This expanded APSA agreement could include;

- increasing government-controlled stockholding in non-IEA, ASEAN Plus Three countries to IEA-equivalent levels: IEA members Japan and South Korea hold more than double the IEA target of 90 days of net imports; ASEAN countries less than half; estimates for China suggest around 50 days;

- a commitment to coordinate the release of stocks, to limit free-riders on stocks released by other countries;

- a commitment to maintain, on a pro rata basis, exports of products refined during a disruption of crude oil supplies. Middle East crude is refined in South Korea, Japan, India and Singapore for export as product. Without such a commitment, the product trade would transmit disruption, resulting in a scramble for supplies; and 
- developing an understanding with the Middle East and other crude oil exporters on how they would allocate remaining supplies in the event of disruption to their own refineries in the region or pro rata to all their customers.

Given the current engagement of the ASEAN Council on Petroleum with the ASEAN Plus Three Oil Stockpiling Roadmap forum and Energy Security Forum, the above improvements to APSA could be achieved by enhanced engagement with these forums.

\subsection{Rationale for Action}

Expanding the membership of the IEA to include emerging economies is crucial if the IEA's emergency response mechanism-the only international coordination mechanism for oil stock release and sharing - is to remain relevant. The alternative is a patchwork of national resilience measures and bilateral producer-consumer arrangements which risk a damaging scramble in the event of a major market dislocation. A more inclusive emergency response mechanism is therefore in the interests of all oil-consuming countries. However, as the world's largest oil importer, China has a particular interest in ensuring international market resilience. China will also benefit indirectly as a result of reduced risk to vulnerable neighbouring oil-importing countries.

Harmonising climate and energy governance regimes with globally agreed decarbonisation objectives could help rationalise global governance, achieving closer alignment between international organisations. In particular, mechanisms and political processes to increase ambition on decarbonisation of the energy sector provide a significant market opportunity for China as a major exporter of low-carbon goods, such as solar photovoltaic panels and batteries. It is also consistent with President Xi's stated wish to protect the Paris Agreement in response to the US withdrawal.

\section{Box 12: Energy Charter Treaty}

The Energy Charter Treaty (ECT) is legally binding and establishes a multilateral framework for cooperation between countries in the energy industry, covering trade, transit, investments and energy efficiency. The treaty contains dispute resolution procedures.

The ECT originated in Russia-EU relations. However, in 2009 Russia announced it did not intend to become a contracting party. In 2015, 72 countries (to date 83 countries), including China, signed the International Energy Charter (IEC); expanding and modernising the ECT. While the IEC is a political declaration and is non-binding, it is a first step towards the international equivalent of the legally binding ECT.

China's accession to the ECT was inhibited by concerns over international arbitration cases. However, as the role and remit of the Belt and Road Initiative (BRI) expands, a common set of rules and mechanisms under the ECT/IEC could be beneficial to China, allowing a common basis for negotiation and agreements, and binding non-WTO BRI countries. Further, a legally binding IEC could provide a low-transaction-cost means to mitigate overseas energy infrastructure investment risks. The benefits to China outweigh the risks of joining, given the balance between China's outward and inward investments, which will accelerate under BRI. The short-term benefits apply primarily to investments in central and eastern European countries (which are already signatures to the ECT), especially for non-WTO members. Given the ECT's origins in the EU and the lack of signatories from ASEAN countries, China could work with the EU and ASEAN Plus Three to develop the IEC towards a legally binding framework. 


\subsection{Strategic Pathways}

China could work through the G20 to reform the IEA and formalise a long-term agenda under the auspices of an enhanced G20 to harmonise global energy and climate governance.

\section{(1) IEA reform}

China could work with emerging economies (including other association countries-India and Indonesia) within the G20 to initiate a process for IEA reform at a summit chaired by an emerging economy (to ensure its priority on the agenda). This could include a five-year roadmap to partnership for the emerging economies based on the precedent of Norway, which is a partner country rather than a full member having never signed the International Energy Programme treaty.

The push for IEA reform could be strengthened by China first cooperating to enhance regional energy security, which has certain structural weaknesses-for example, through ASEAN Plus Three (see Box 11), the International Energy Charter (see Box) and regional cooperation on gas (see Box 13). This would still allow China to improve its energy security and hedge against the possible failure of IEA reform, for example were it to be blocked by member countries. It would also signal to IEA member countries that China is serious about strengthening energy security governance.

\section{Box 13: Regional gas security}

Asia is the world's largest consumer of liquefied natural gas (LNG), and the most vital incremental demand market. As such, the region has known extremely high spot prices in periods of limited supply. While new supplies seem set to outstrip demand in the coming years, buyers should not become complacent. China should view the backdrop of well-supplied LNG markets as an opportune time to promote regional frameworks to enhance natural gas security and promote greater flexibility of supplies.

These could include a concerted push for less rigid contracts with volumes delivered through open destinations or more flexible redelivery clauses. A regional pricing hub, that would be indexed to gas rather than oil prices, would also provide more accurate pricing signals to shift volumes from one destination to another. Finally, storage capacity will support a more robust and flexible gas market. China has already issued targets to increase its gas storage capacity and could work with other countries to develop similar infrastructure, which could then be coordinated more effectively in times of shortage. North-east Asia would be the most natural starting point given the concentration of large buyers there, but ASEAN Plus Three would also offer a convenient framework, bringing together regional consumers and producers (Fig. 33).

\section{Box 14: Mission statements of key international organisations}

The Energy Charter Treaty provides a multilateral framework for energy cooperation that is unique under international law. It is designed to promote energy security through the operation of more open and competitive energy markets, while respecting the principles of sustainable development and sovereignty over energy resources.

The International Energy Agency works to ensure reliable, affordable and clean energy for its 29 member countries and beyond. Its mission is guided by four main areas of focus: energy security, economic development, environmental awareness and engagement worldwide. 


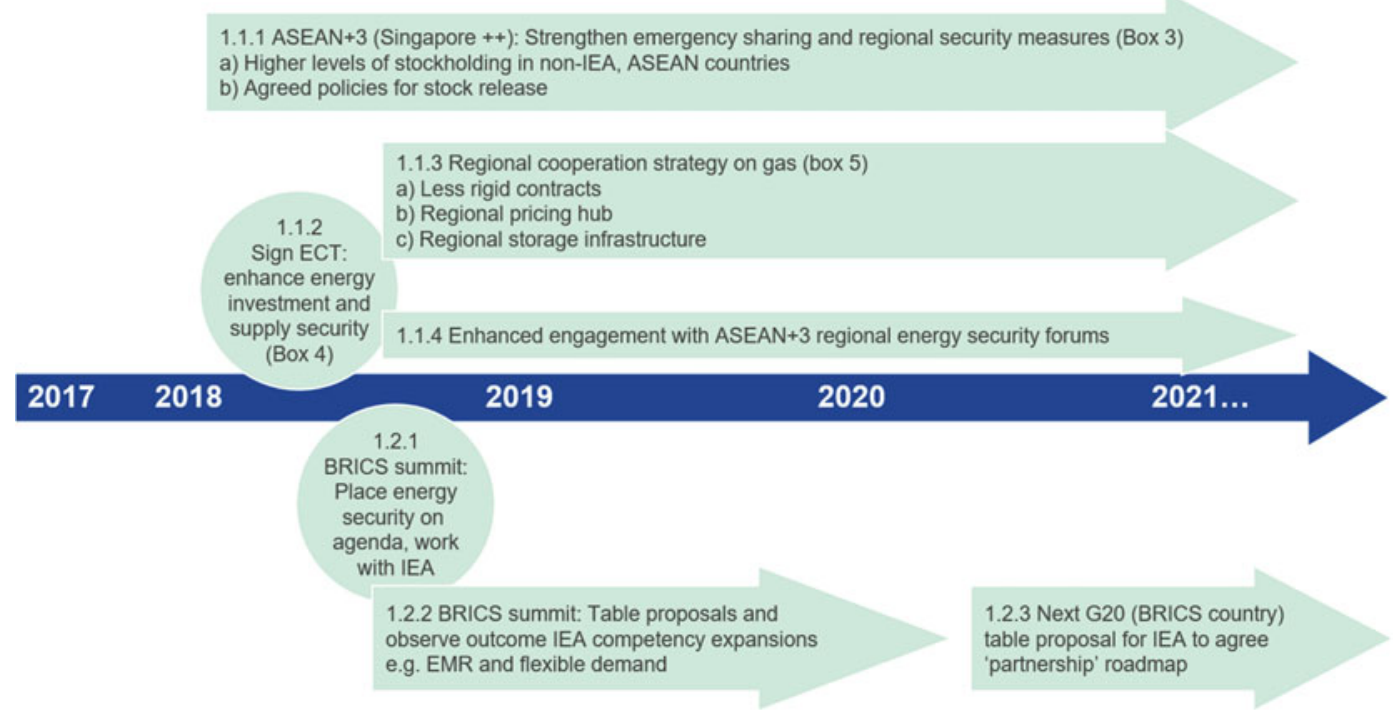

Fig. 33 Timeline of action plans under strategic pathway: reform the IEA to make it more representative, effective and relevant. Note ASEAN Plus Three $=$ the Association of Southeast Asia Nations and the three East

The International Energy Forum, as the neutral facilitator of open dialogue on energy with key global oil and gas actors, helps ensure energy security and transparency.

The International Monetary Fund's fundamental mission is to help ensure stability in the international system. It does so in three ways: keeping track of the global economy and the economies of member countries; lending to countries with balance of payments difficulties; and giving practical help to members.

The International Partnership for Energy Efficiency Cooperation seeks to accelerate the adoption of energy efficiency policies and practices. It assists member countries to identify and share proven, innovative practices and data on energy efficiency to better inform decision makers.
Asia nations of China, South Korea and Japan; ECT = Energy Charter Treaty; BRICS = Brazil, Russia, India, China and South Africa; EMR = electricity market reforms

This also serves to foster bilateral and multilateral initiatives between countries.

The International Renewable Energy Agency is an intergovernmental organisation that supports countries in their transition to a sustainable energy future. It serves as the principal platform for international cooperation, a centre of excellence, and a repository of policy, technology, resource and financial knowledge on renewable energy.

The United Nations Framework Convention on Climate Change (UNFCCC) provides the foundation for multilateral action to combat climate change and its impacts on humanity and ecosystems.

The World Bank has set two ambitious goals to push extreme poverty to no more than $3 \%$ by 2030 , and to promote shared prosperity and greater equity in the developing world. 
(2) Harmonisation of global energy and climate governance

China could seek to initiate a long-term agenda, under the auspices of the G20, to help align global energy governance and climate governance regimes to accelerate the transition to a low-carbon, energy-secure future. First, groundwork steps could seek to position the G20 as a forum for political leadership and consensus on the transition to a low-carbon, energy-secure future through a series of statements and commitments on secure, long-term decarbonisation and collective efforts to raise the ambition of nationally determined contributions (NDCs) (see Box).

This could be followed up by the G20 launching a global energy governance reform agenda to align international organisation mission statements with the common goal of a secure, low-carbon energy transition as enshrined in the Paris Agreement and UN Sustainable Development Goals (see Box). This would need to be complemented with steps to build the G20's leadership and oversight function by: (i) establishing a long-term series of G20 energy ministerial meetings; and (ii) building its institutional capacity through an energy secretariat function distributed among the relevant international organisations.

\section{Box 15: Increasing NDC ambition}

Closing the gap between the emission reductions pledged under existing NDCs, and those needed to achieve the Paris goals, will be addressed through a process every five years at the UNFCCC, where governments progressively increase the ambition of their NDCs.

\section{Annual global total greenhouse gas emissions $\left(\mathrm{GtCO}_{2} \mathrm{e}\right)$}

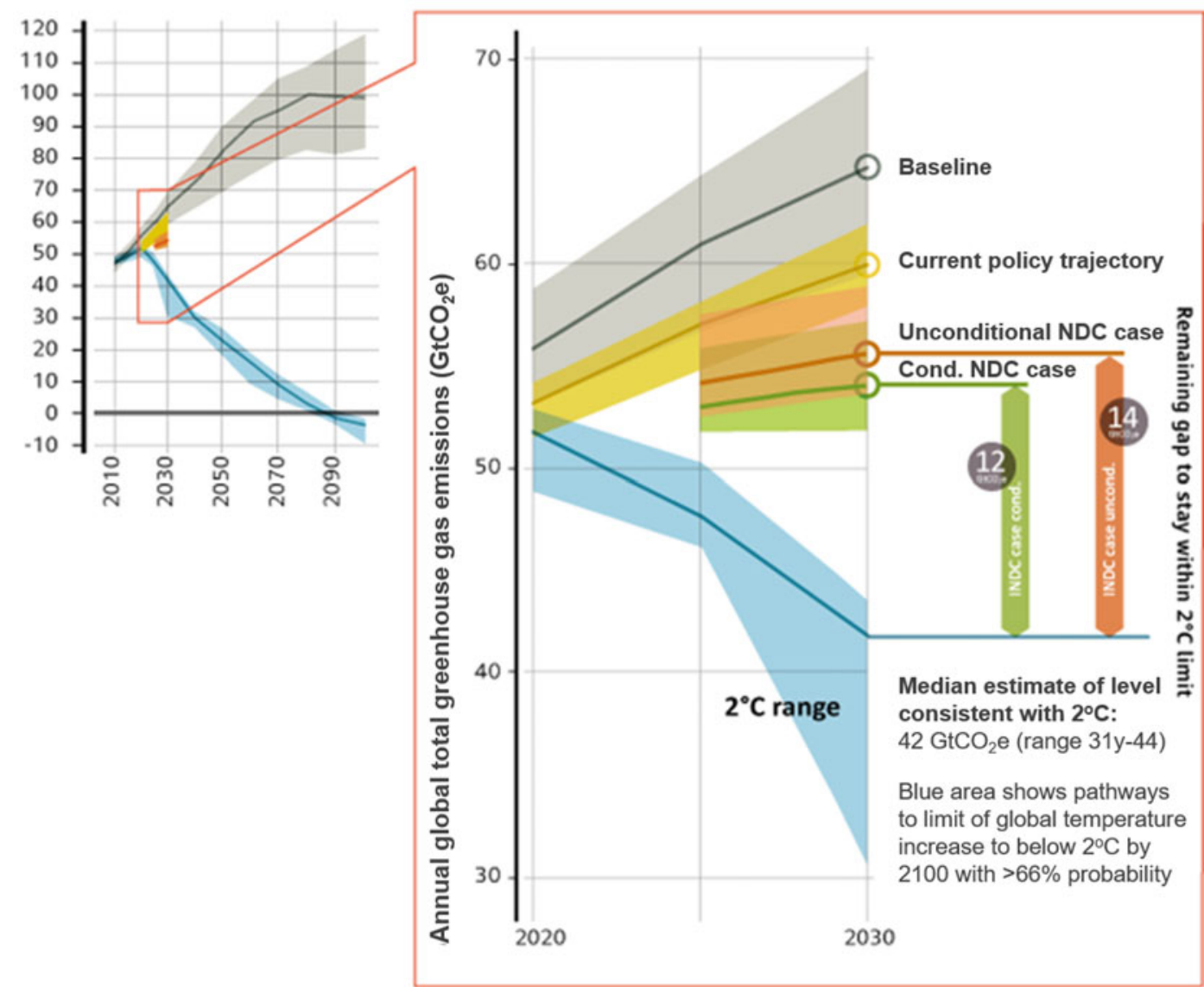




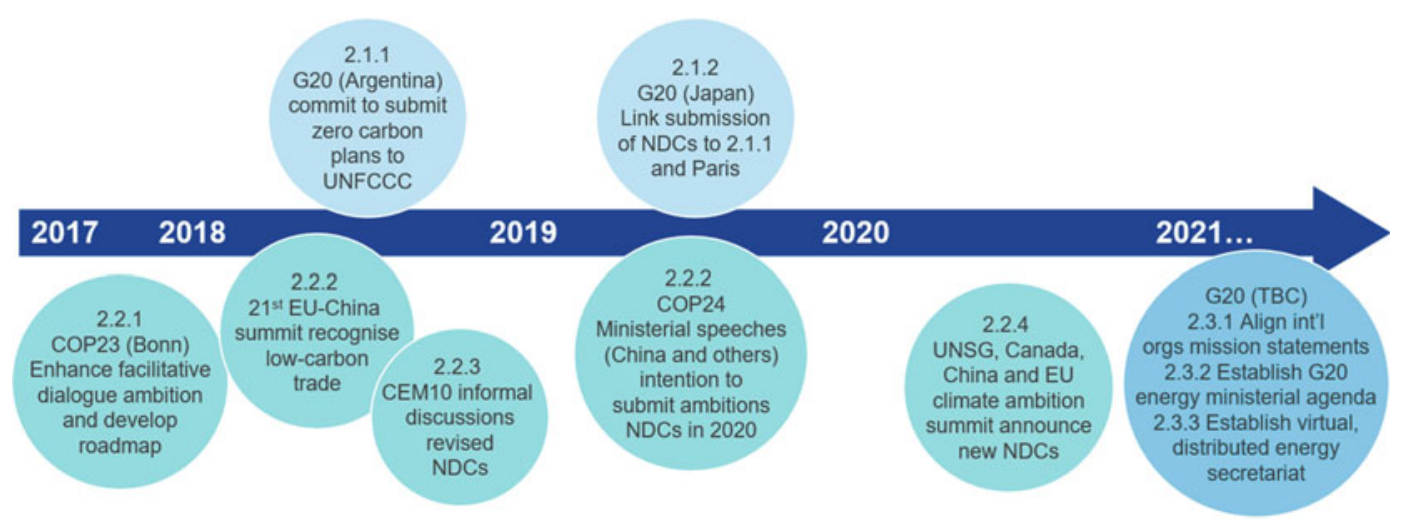

Fig. 34 Timeline of action plans under the strategic pathway: harmonise global energy and climate governance to facilitate the transition to a low-carbon, energy-secure future. Note UNSG = United Nations

As the largest emitter in the world, China will be critical to any credible global effort to increase NDC ambition. Chinese ambition (alongside that of the USA) was similarly crucial to setting expectations in the run-up to Paris in 2015. Although it would be unrealistic to suppose that a similar US-China dynamic can be recreated with the current US administration, China could seek other developed country partners.

Importantly for China, leveraging its own NDCs to increase the ambition of other developed country NDCs makes sound economic sense. The resultant demand for low-carbon goods in developed economies could provide large export opportunities for Chinese manufacturers.

This could begin with diplomatic efforts to achieve progressively more ambitious language on emissions at the G20, culminating in a statement of intent on NDC ambition in 2020 that is repeated at five-yearly intervals in increasingly determined terms. Supportive activities could include using EU-China summits and the Clean Energy Ministerial as forums to signal intent and discuss new NDCs and, more ambitiously, a summit with the UN Secretary-General, EU and
Secretary-General; $\mathrm{COP} 23=23$ rd Conference of the Parties to the United Nations Framework Convention on Climate Change (UNFCCC); CEM10 = 10th Clean Energy Ministerial

other progressive governments to announce revised NDCs in early 2020 (Fig. 34).

\subsection{Risks and Obstacles}

The principal risks to these strategies are political: US antipathy towards climate policy would make progress through the G20 more difficult and may strengthen the positions of less progressive governments such as Saudi Arabia and Russia (although it should be noted that following the US withdrawal from the Paris Agreement, both restated their support). The Germany-chaired 2017 summit ultimately saw a G19 statement on climate change that excluded the USA, establishing the precedent for circumventing its obstructiveness. For more ambitious reforms, it may be necessary to wait until a more receptive US administration is in place.

Other political risks relate to the expansion of the IEA - in particular, some member countries may be resistant for fear of having their voting shares diluted. By seeking expansion of the IEA through partnership arrangements - such as that with Norway-rather than full participation (which would entail reforming the International Energy Programme treaty as well), this issue could potentially be avoided. IEA members would benefit from expansion and an empowered IEA when the next energy crisis emerges. 
The G20's lack of a supporting institutional infrastructure and its fluctuating agenda present an obstacle to the forum acting as a leadership and oversight mechanism for the energy transition. This could be addressed directly through reforms to build a distributed secretariat function and initiate an energy ministerial track to facilitate such a function. However, formalising the G20 to this extent is likely to be met with caution from governments reluctant to accept further international obligations.

\section{Investment Regimes for Low-Carbon, Energy-Secure Transition}

Attention regarding the risks of the rapidly accelerating energy transition is growing among policymakers, central banks, regulators, institutional investors and financiers. Allocating investment during a swift energy transition, while maintaining oil and gas supply security and reliability of electricity networks, requires clear market signals and a level playing field.

Several investment mechanisms, finance sector rules and market structures could provide this clarity, given the correct reforms. These mechanisms, rules and structures fall roughly into two categories: first, international governance arrangements to help optimise global capital allocation; and second, engagement within countries to improve national governance of the energy sector and access to finance and technologies.

\section{Box 16: The challenge of optimal capital investment across the energy system}

Ensuring the appropriate level of investment in the oil and gas sectors is achieved -in parallel to investment in the growing renewable, electric vehicle and battery storage markets - is a fine balancing act. The Energy Transitions Commission, and New Climate Economy, anticipate that a $2{ }^{\circ} \mathrm{C}$ world requires $\$ 21.3$ trillion invested across all energy sectors-including exploration, production and distributionbetween 2015 and 2030. As Fig. 35 illustrates, this implies an average of $\$ 566$ billion per year in hydrocarbons and $\$ 500$ billion per year in renewables, which equates to increases of $31 \%$ and $68 \%$ respectively on 2016 expenditure.

Upstream oil and gas expenditure will be cut by an estimated \$1 trillion between 2015 and 2020, as a result of continued low prices and slack global demand. In 2016, upstream oil and gas investment

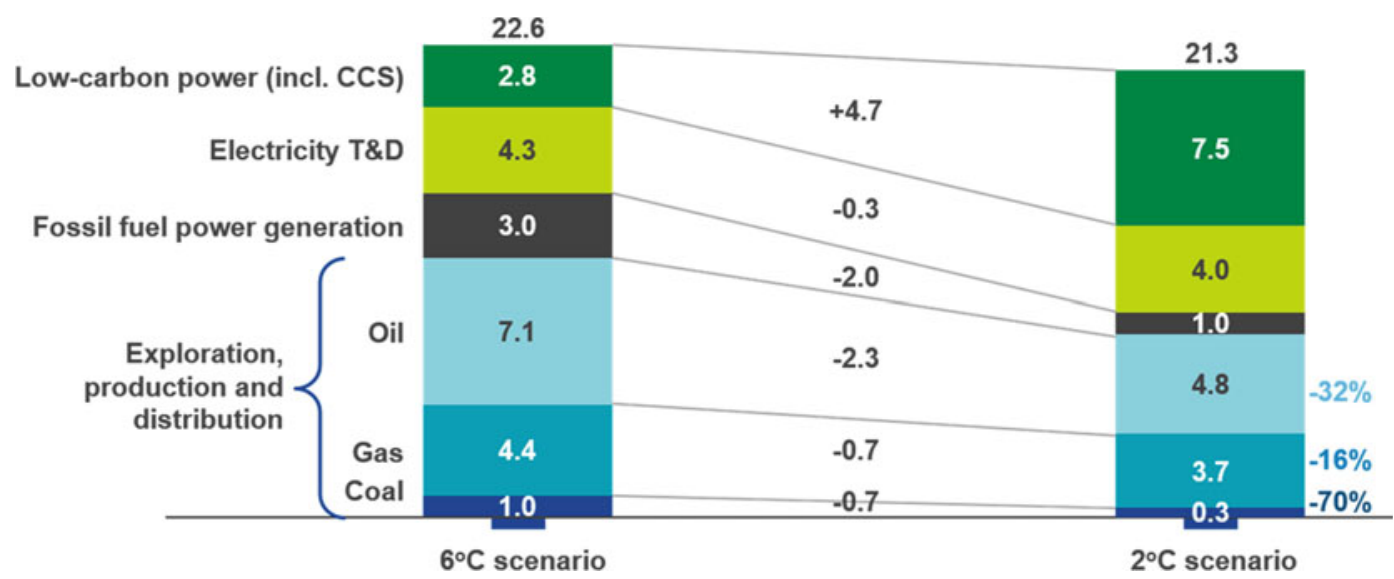

Fig. 35 Investment requirement in energy, 2015-30 ( $\$$ trillion, constant 2010 dollars). Note CCS = carbon capture and storage; $\mathrm{T} \& \mathrm{D}=$ power transmission and distribution 
fell $26 \%$ due to reduced drilling, which comprises two-thirds of the sector's total investment. Offshore spending is expected to decline by $20-25 \%$ in 2017 alone. Yet these aggregate figures mask very different approaches to commercial risk in upstream investments between international and national oil companies (IOCs and NOCs): while European and US IOCs are expected to scale back investment in 2017 by a further $7 \%$ and $15 \%$ respectively, NOCs plan to increase spending by $9 \%$. Meanwhile, investment in renewables fell by $23 \%$ in value in 2016; although more capacity was added to the global grid than ever before, thanks to declining costs. Both these trends, across the renewables and oil and gas sectors, are contrary to the investment required under a $2^{\circ} \mathrm{C}$ energy-secure world. This is partly due to the market not receiving correct signals regarding risks and benefits and lack of clarity over how the energy transition will progress.

The construction of market structures and investment mechanisms should remain technology-agnostic, allowing the market to select the optimal technologies. On the basis of the market providing a level playing field, with climate risks evaluated in costs and benefits, this agnostic stance should be applied to clean energy as well as fossil fuel technologies. That said, there are certain technologies where high capital costs and network expansion costs require greater support. Examples of such technologies, in relation to China's 13th Five-Year-Plan (2016-20), are offshore wind and high-voltage power transmission. In such instances, multilateral development banks and public-private partnerships could be used to direct additional investment, alongside partnering with countries that have expertise with a given technology (Fig. 36).

\subsection{Global Governance of Investment Regimes}

Uncoordinated or unaligned investment policies will be insufficient to achieve energy security and the long-term goal of the Paris Agreement.

The Financial Stability Board Taskforce on Climate Disclosure is a potential game-changer. Its recommendations for companies on voluntary, consistent climate-related financial disclosures are a clear first step to providing better information to investors and other market players on the risks to business models and balance sheets presented by the low-carbon transitionso-called transition risks. These recommendations may require further development, for instance on their application by state-owned enterprises and in less liberalised markets. The metrics by which companies disclose in different sectors will also need to be tested and refined, and the scenarios under which these metrics sit require methodological standardisation across geographies and industries. While recommendations can be voluntarily adopted by companies, state backing by China and its G20 partners
Fig. 36 Global investment in energy supply by fuel

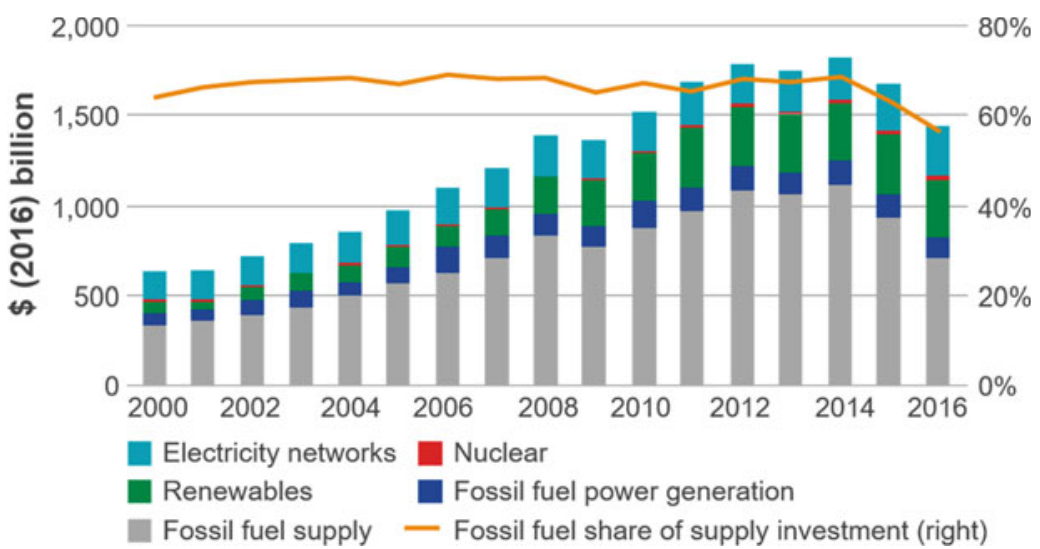


will send a strong signal—stimulating implementation.

Ultimately, incorporating transition risks into the cost of investment capital will help allocate investments to where they are needed to provide energy security through the transition, though further development of the recommendations across diverse jurisdictions and sectors is required to mitigate unintended negative consequences of disclosures.

Carbon pricing can also help, by providing a market signal through demand for energy products and services; it is the most efficient economic mechanism to deliver decarbonisation. The failure to implement carbon pricing regimes and increase their global coverage will significantly hinder the achievement of national climate policy and international commitments under the Paris Agreement - to the detriment of all countries. The slowdown in momentum to expand carbon pricing, either as a trading system or as a tax, has recently taken off again. The Carbon Pricing Leadership Coalition (CPLC) represents 21 countries, five Canadian and US states, and almost 140 global corporations. In January 2016 the CPLC challenged global governments to double carbon pricing coverage by 2020 and double again by 2030 . The Republican-led Climate Leadership Council recently proposed establishing a $\$ 40 /$ tonne carbon tax and dividend scheme within the USA.

Early emissions trading system (ETS) adopters have lessons to offer on the impacts of conflicting policies and poor adoption strategies on establishing stable and effective pricing. For instance, the cost-effectiveness of an ETS and achieving an effective price can be undermined by policymakers inadequately attempting to balance the trade-off of reduced industrial competitiveness by introducing competing policies or reducing sectorial coverage. If these lessons can be leveraged through lesson sharing - along with designing for compatibility and robust monitoring, reporting and verification procedures - the likelihood of success of China's ETS and others will increase.

Carbon leakage may undermine the effectiveness of carbon pricing (carbon leakage is where the restructuring of high-carbon industries, for example, encourages an outflow of capital and technologies beyond national borders). Regional and international coordination to link carbon markets, through mechanisms such as Article 6 of the Paris Agreement on transferable allowances, could minimise carbon leakage. Studies have shown that in a non-linked EU ETS, energy emission leakage peaks at $16 \%$. If however, the EU and China linked, once the Chinese ETS is established, energy emission leakage could peak at $8.5 \%$ (see Figs. 37 and 38). However, linking carbon pricing schemes is not straightforward and is a risky endeavour. For example, linking carbon trading schemes between Europe, California and Quebec led to price volatility, not stability. This is likely to be due to differences in the regulations governing each jurisdiction, and the interactions of
Fig. 37 EU ETS non-linked: energy emission leakage peaks at $16 \%$

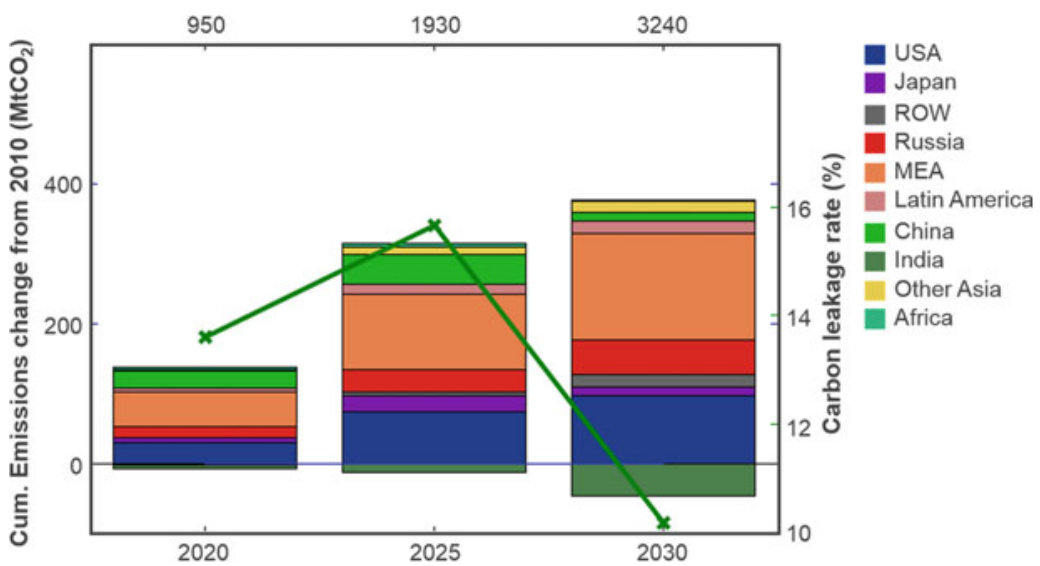


Fig. 38 EU-China ETS linked: energy emission leakage peaks at $8.5 \%$

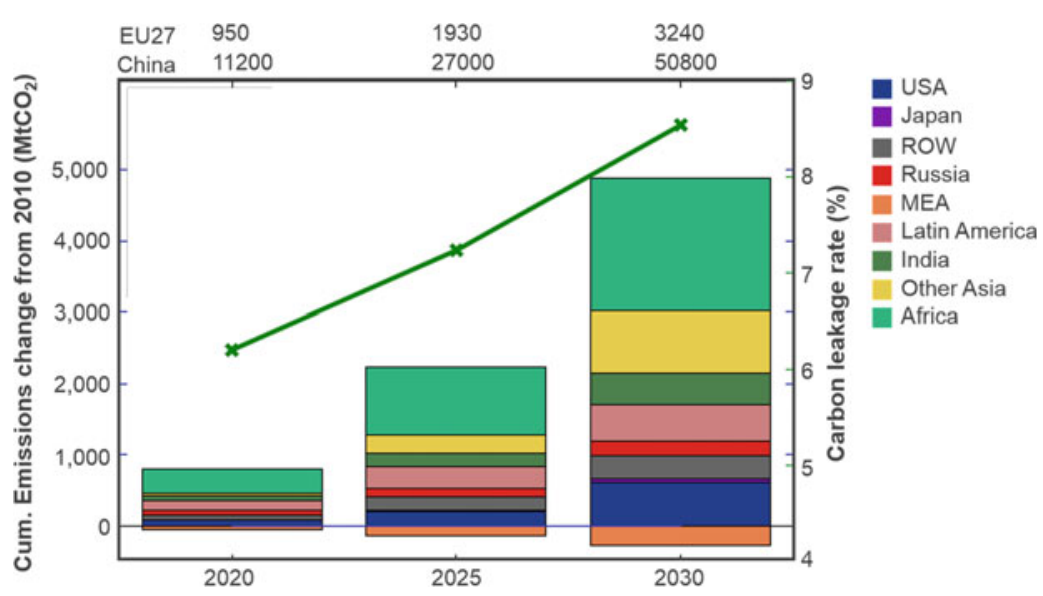

Lower oil prices have given political and fiscal breathing space for countries such as Indonesia, which successfully phased down consumption subsidies for citizens or industries as fossil fuel prices collapsed. Of 157 countries, 84 either reduced consumption subsidies or increased petrol taxes. But as consumption has shifted towards nations that have maintained subsidies or lowered petrol taxes, subsidy reforms have been undermined at the global level (Fig. 39).

\subsubsection{Cooperation Opportunity}

As China strives to open up its domestic markets to foreign investment, commercial transparency and the disclosure of climate-related risk will be key factors in building the confidence of international investors. At the same time, China is establishing the world's largest carbon market; the success of which will be partly contingent on minimising policy conflicts, particularly where
Fig. 39 Estimates for global fossil-fuel consumption subsidies and subsidies for renewables

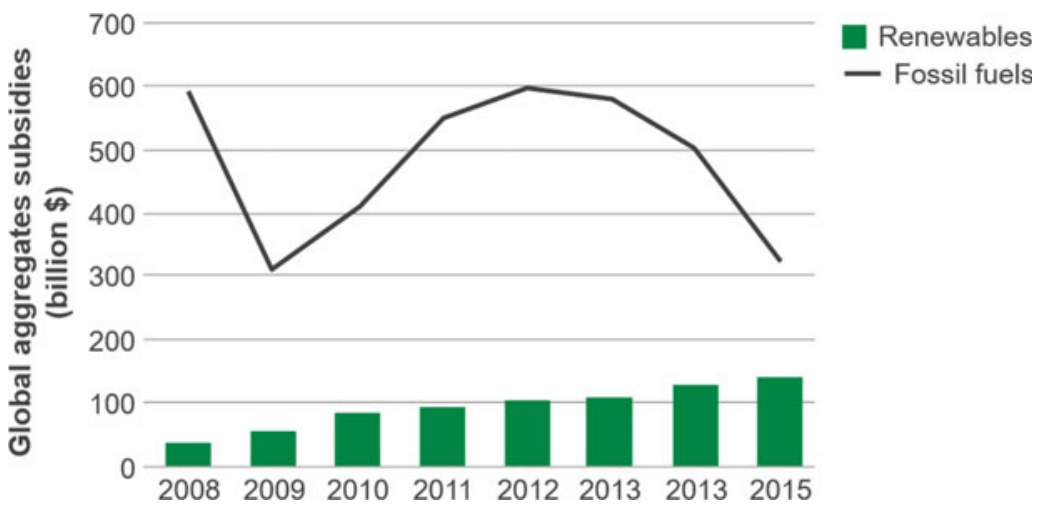


the distortions associated with fossil fuel subsidies and the impacts associated with carbon leakage are concerned.

Given the political importance of managing the transition to a market-led economy and slower but higher quality economic growth at home, policy support for measures to disclose climate-related financial risks and develop effective carbon pricing mechanisms are well aligned with China's strategic priorities.

\subsubsection{Outcome}

The targeted outcome is a global market risk disclosure structure and carbon pricing mechanisms that optimally allocate capital across all aspects of the global energy system, maintaining energy security while achieving the goals of the Paris Agreement.

To achieve such an outcome China could adopt two distinct strategic governance pathways:

(1) collaborate with G20 states to support the development, adoption and implementation of FSB TCFD energy sector recommendations, and;

(2) support the phase-out of fossil fuel subsidies and establish carbon pricing mechanisms that are fit for a low-carbon, energy-secure system.

\subsubsection{Using the $\mathbf{G 2 0}$ and Other Multilateral Platforms to Drive Reform}

Given that the TCFD was established by the Financial Stability Board, whose board members include the central bankers of all G20 major economies, the G20 is well placed to drive further development and adoption of TCFD recommendations. Further, while the commitment to fossil fuel subsidy phase-down wasn't reaffirmed at the G20 2017 Hamburg meeting, the G20 has been pivotal in global subsidy reform since 2009 . China could therefore use the experience of G20 to drive reforms in partnership with other leading G20 economies.

There is currently no single institutional or organisational home for the governance and coordination of carbon pricing. However, China could work with several multilateral organisations to expand the effectiveness of carbon pricing, such as at the UNFCCC on transferable allowances, the EU and the Carbon Pricing Leadership Coalition on linking and carbon clubs, or with the WTO on border adjustment measures.

\subsubsection{Rationale for Action}

In the case of China, greater transparency of capital markets may help foster confidence in foreign investors. More broadly, as a major energy consumer, China will benefit from optimal capital allocation in the energy sector through the transition, which would help avoid possible supply crunches that may result from investors failing to appreciate transition risks and investment requirements. Finally, as a carbon-pricer, China has an interest in international carbon pricing to avoid damaging the competitiveness of its heavy industries.

From the perspective of China's partners, Chinese-state backing of TCFD recommendations, fossil fuel subsidy reform, and the establishment of effective carbon price mechanisms will all help stimulate development and implementation. Further, China's partners will benefit from an equalisation between increasingly penalised OECD carbon-intensive sectors and the competitive advantage of Chinese carbonintensive exports.

\subsubsection{Strategic Pathways}

(1) G20 states support development, adoption and implementation of FSB TCFD recommendations

Developing and adopting the TCFD framework could be achieved by China working with G20 member states and future Chairs to establish a trilateral working group under the G20 process. This could bring together the Financial Stability Board (FSB), the G20 Energy Ministerial and energy sector participants in the Business 20 dialogue, with a view to unlocking some of the challenges of TCFD development and implementation. In the 


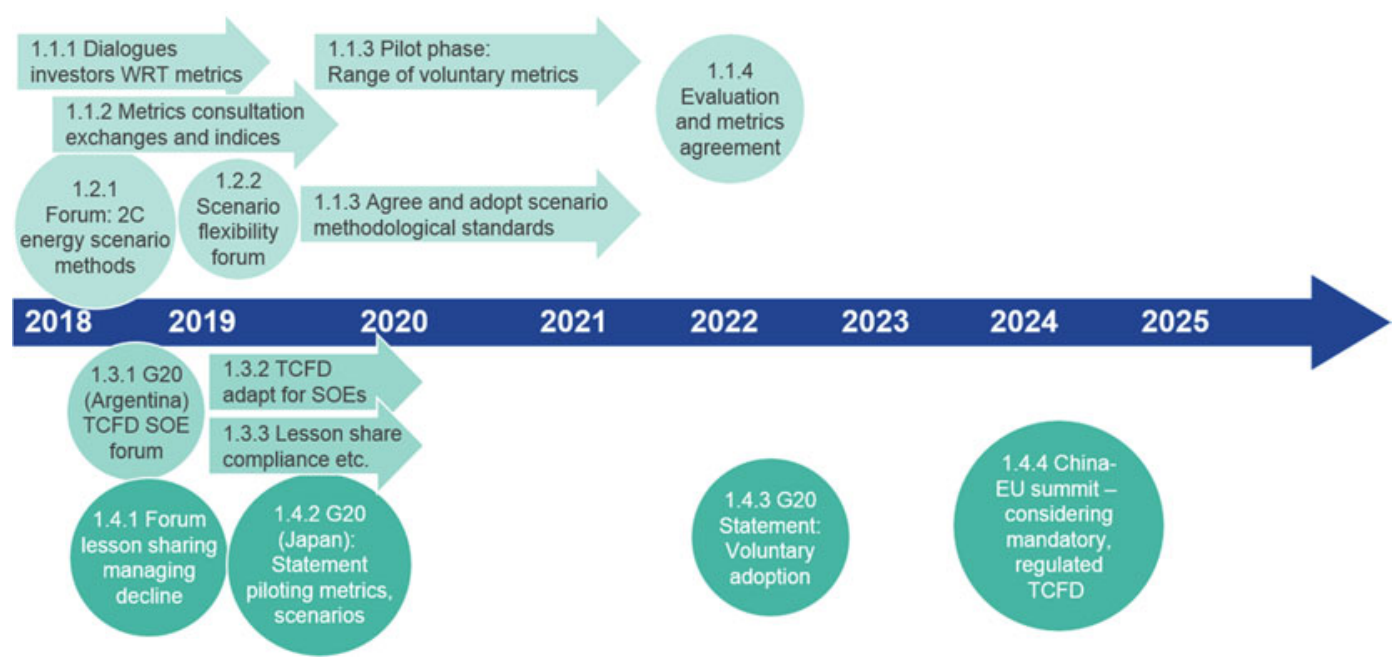

Fig. 40 Timeline of action plans under the strategic pathway: collaborating with G20 states to support the development and adoption of FSB TCFD energy sector recommendations

first instance, this could include: (i) definition and testing of disclosure metrics; and (ii) methodological standardisation of energy scenarios across geographies and industries under which disclosures are made. The recommendations also require: (iii) adaptation for public finance, including state-owned enterprises and policy banks; and (iv) building momentum of G20 governments committed to FSB TCFD recommendations and facilitating implementation (Fig. 40).

\section{(2) Fossil fuel subsidies and carbon pricing mechanisms fit for purpose}

Global governance of an internationally coordinated phase-down of fossil fuel subsidies could be achieved by China working with G20 partners to foster a renewed G20 focus on fossil fuel subsidies. Establishing effective carbon pricing mechanisms could be enabled by China working with a variety of international forums to encourage international lesson sharing of best practice in establishing domestic carbon prices, alongside international cooperation to minimise carbon leakage (Fig. 41).

\subsubsection{Risks and Obstacles}

Where the development and adoption of FSB TCFD energy sector recommendations is concerned, confidence building measures will be critical. High-level commitment to the development of FSB TCFD metrics and scenarios would help send a clear message to the market and have the potential to encourage widespread voluntary adoption. Mandatory adoption will be politically difficult, but with strong state backing is unlikely to be necessary, as was learnt from the Financial Stability Forum recommendations on Enhancing Market and Institutional Resilience after the 2008 financial crisis.

Renewed G20 focus on fossil fuel subsidy phase-out will face similar obstacles to previous subsidy reform efforts, where progress has been undermined by the inconsistencies in reporting. The process was further undermined by the US position in 2017, which ultimately resulted in the G20 Hamburg Communique's failure to reaffirm fossil fuel subsidy commitments. The USA is a key player in ensuring subsidy reform and has worked with China to peer-review progress on subsidy reform in the past. 


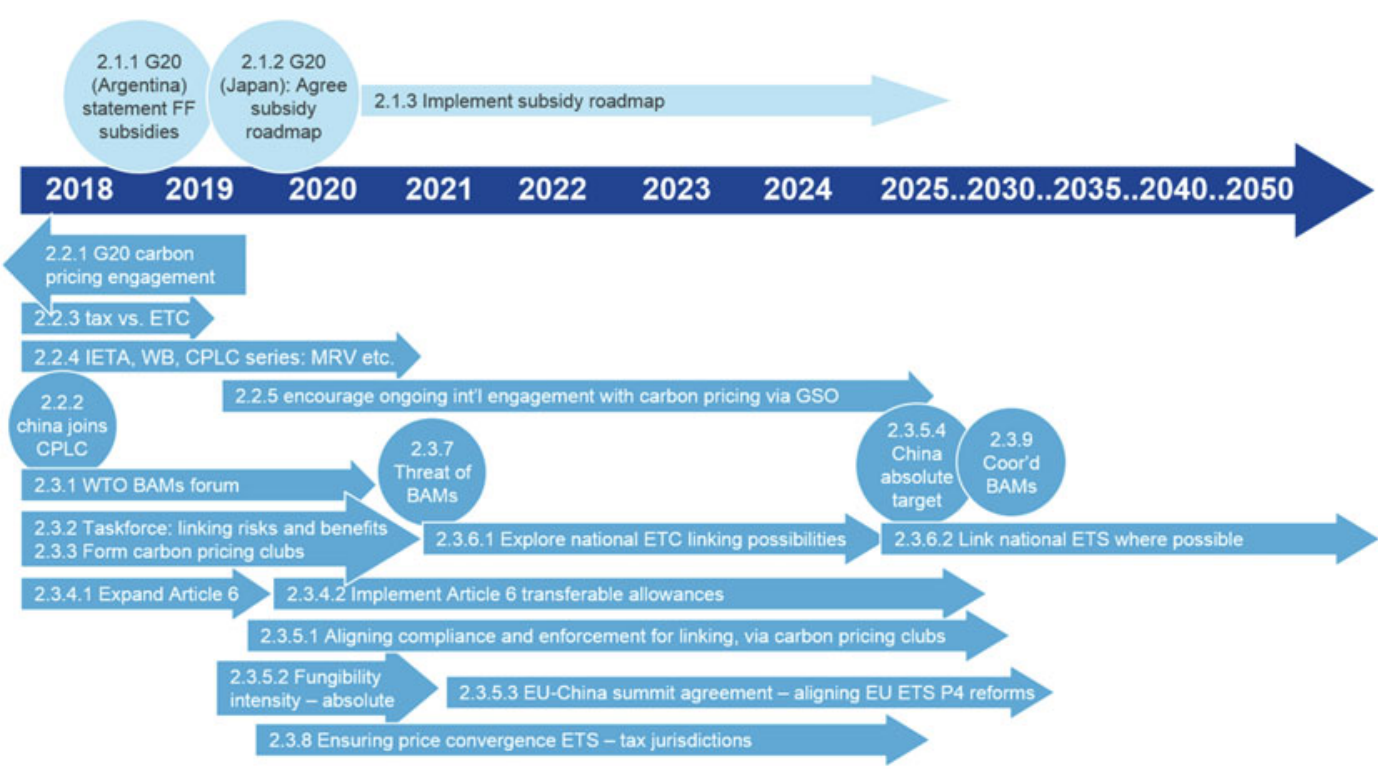

Fig. 41 Timeline of action plans under the strategic pathway: global phase-out of fossil fuel subsidies and establishing carbon pricing mechanisms fit for a low-carbon, energy-secure system

There is a significant risk from linking the China emissions trading system with other jurisdictions. Should this result in failure-for example problems with monitoring, reporting and verification (MRV), price instability or a prolonged price collapse-it could represent an insurmountable setback to the internationalisation of carbon trading. Cooperation with other carbon-pricing jurisdictions to establish clubs of free-trading economies with border adjustment measures on non-member countries may therefore be a less risky way to encourage propagation.

\subsection{International Cooperation on National Energy Sector Investment}

Over the past decade, China has rapidly increased its foreign direct investment (FDI) in overseas energy sectors as part of its Go Out strategy. Over the coming decades, the Belt and Road Initiative (BRI) looks set to channel unprecedented outflows of Chinese capital into energy resources and infrastructure, and higher up the value chain in new technologies and infrastructure. By some estimates, the scale of these investments could be up to $\$ 900$ billion.

China has an interest in ensuring good energy sector governance in partner countries where it invests. This will help mitigate the risks of instability and underinvestment in these countries, enhancing China's energy security as a result (see Box 17). China can also cooperate with partner countries to support them through the transition, especially by providing access to low-carbon technologies produced by Chinese companies (see Box 18).

The way that China approaches investments along the BRI will be a measure of China's commitment to green and sustainable growth, both at home and abroad for many of its international partners. ${ }^{2}$ Learning from past experience and minimising the risk of investment disputes with host countries and underperforming assets - by adhering to high standards of social and environmental governance and developing

\footnotetext{
${ }^{2}$ See Navigating the New Normal for an in-depth exploration of China's evolving approach to FDI and the BRI: https://www.chathamhouse.org/publication/ navigating-new-normal-china-and-global-resourcegovernance.
} 
appropriate risk management tools-is one key aspect of this. At the same time, Chinese oil companies have paid around $20 \%$ above the industry average for oil and gas assets. Together, these factors have affected the profitability of Chinese FDI in the hydrocarbon and mining sectors, leading some Chinese officials to question the performance of such investments.

Avoiding carbon leakage is another factor, as China's domestic economy undergoes structural transition and as high-carbon capital and technologies seek an escape valve in the BRI. President $\mathrm{Xi}$ Jinping proposed an "international coalition for green development" at the first Belt and Road Forum for International Cooperation in Beijing in 2017; and greening the BRI has risen up the policy agenda.

\section{Box 17: Minimising investment risks through enhanced governance}

The risks to fossil fuel and clean energy infrastructure investments in host countries, especially in developing countries whose regulatory and governance structures are weak, can be minimised by the development and implementation of strong international standards. Targeted governance mechanisms have evolved to help minimise the risk of some of the negative governance and societal impacts associated with resource development and trade. These range from the transparency of resource revenues under the Extractive Industries Transparency Initiative (EITI) to certifying that raw mineral supply chains are conflict-free through the OECD and the due diligence guidelines of the China
Chamber of Commerce of Metals Minerals \& Chemicals Importers \& Exporters (CCCMC).

The EITI aims to enhance transparency around resource-related payments to governments. The EITI transparency standards require disclosure along the value chain as to how revenue makes its way through the government and contributes to the economy. At the same time, environmental, social and governance (ESG) risk frameworks that originated in multilateral banks, such as the International Finance Corporation's (IFC) Environmental and Social Performance Standards, are increasingly referenced in the market.

China is not an EITI member country, but its companies are active in implementing EITI standards in countries like Iraq and Mongolia. While there is the potential for tension between the initiative's mechanism and China's core foreign policy principle of non-interference, China has approved EITI's principles and strongly supported the EITI in international forums. The EITI is perhaps the most high-profile of a suite of governance mechanisms and technical competencies that resource investors have developed, in order to safeguard relationships and investments with host governments and communities, often in collaboration with multilateral banks. Figure illustrates some of the areas of governance support and capacity building around a hydrocarbon development (Fig. 42). 


\section{Potential policy objectives}

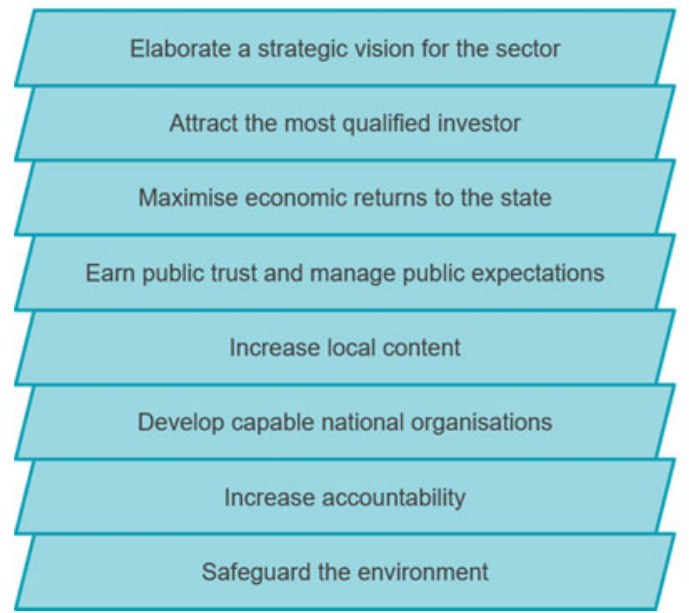

\section{Assessment and prioritisation}

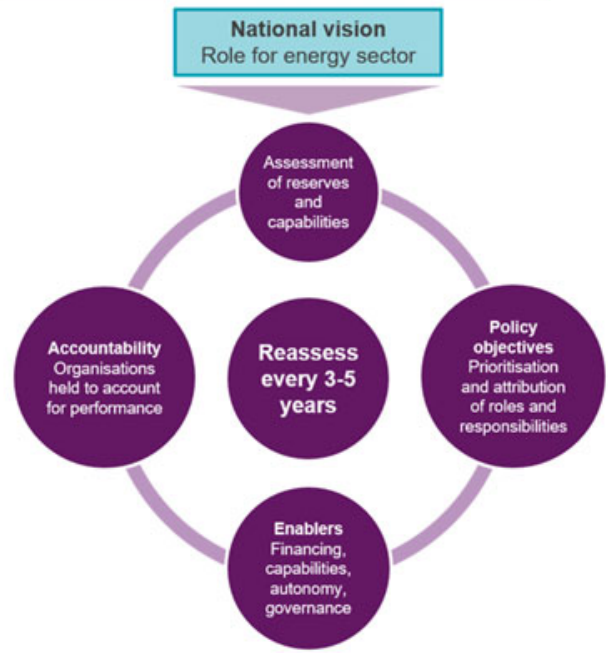

Fig. 42 Recommendations for incremental resource governance improvements by the Chatham House New Petroleum Producers Discussion Group

As clean energy FDI expands along the BRI and across developing countries, the environmental, social and governance (ESG) risk frameworks that underpin fossil fuel investments are equally relevant. ESG standards that originated in multilateral banks as minimum investment standards - such as the International Finance Corporation's (IFC) Environmental and Social Performance Standards - are increasingly referenced in capital markets. The Equator Principles, for example, apply to all commercial bank lending and require investments to meet IFC performance standards. These de-risking tools are equally applicable to low-carbon investments, because they are scaled and as public-private partnerships increase in importance. They are also crucial to the development of the Chinese-led Asian Infrastructure Investment Bank, which has committed to meet or exceed the multilateral investment standards of its peers.

\section{Box 18: Candidate countries for investment and technology packages}

Many developing countries, some of which are in the BRI, could greatly benefit from clean energy technology and investment packages. The Climate Vulnerable Forum (CVF) represents those countries most at risk from the impacts of climate change, and therefore with most to gain from such packages. All 48 members of the CVF have pledged to ensure $100 \%$ of energy production is from renewable sources "as rapidly as possible", and by $2030-50$ at the latest.

The CVF applied more pressure at the UNFCCC Bonn Climate Change Conference in May 2017. The forum's formal statement by Ethiopia, read as follows:

In accordance with... the Paris Agreement, we are of course calling for a rapid scaling up of predictable, adequate and sustainable financing that should be balanced and readily accessible, together [with] capacity and technological assistance from developed countries to address climate risks.

Of the 48 members, 13 are BRI countries, expanding to 27 with the inclusion of 
developing countries in Africa. Given China's interest in exporting clean energy technologies to BRI and African countries, combined with the need to ensure that Chinese companies retain their societal licence to operate, providing packages for these countries has the potential to be a win-win approach.

\subsubsection{Cooperation Opportunity}

China is in a unique position to work with BRI partner countries on a low-carbon, energy-secure transition by creating the frameworks for FDI and energy infrastructure development in clean energy technologies. At the same time China could work with others to enhance the governance and transparency of energy sector investments in line with best practice standards, such as the EITI.

Targeted outcome: stable energy transitions in partner countries, facilitated by:

- harmonised portfolio standards and strategies of multilateral development banks (MDBs), policy banks and export credit agencies (ECAs);

- investment and technology packages for developing country partners; and

- support for energy sector good governance.

To achieve such an outcome China could adopt two intrinsically linked strategic cooperation pathways:

(1) multilateral coordination on phasing down FDI and development finance for high-carbon projects, while implementing international best practice on environmental, social and governance standards; and

(2) cooperation strategies with developing countries, MDBs and climate finance providers to increase access to clean energy technologies and alternative development pathways.

\subsubsection{The BRI as a Focal Point for Cooperation with Financial Institutions and Regional Forums}

BRI countries provide an obvious focus for cooperation in this regard. Other developing country groupings with high demand for renewable technologies that could be met under (2) above include the Africa Renewable Energy Initiative (AREI) through the Forum on China-Africa Cooperation (FOCAC) and the Climate Vulnerable Forum. Supporting investment packages could be developed in collaboration with developed country partners via MDBs and international coordination and support mechanisms such as the OECD Development Centre and the International Renewable Energy Agency (IRENA).

\subsubsection{Rationale for Action}

Benefits for China include:

- better governance in oil and gas producing developing countries, improving overall energy security;

- improved societal licence to operate for Chinese companies by joining the EITI, for example, and engaging in technology transfer projects; and

- contributing to sustainable investments in BRI countries.

Benefits for partner countries include access to climate finance and low-carbon technologies, and support with national governance reforms where needed.

\subsubsection{Strategic Pathways}

(1) Phasing down high-carbon FDI and development finance, and enhancing best practice ESG standards

The phase-down of FDI into high-carbon sectors could be achieved by China working to: (i) establish BRI and G20 working groups to align the standards and strategies of MDBs and 


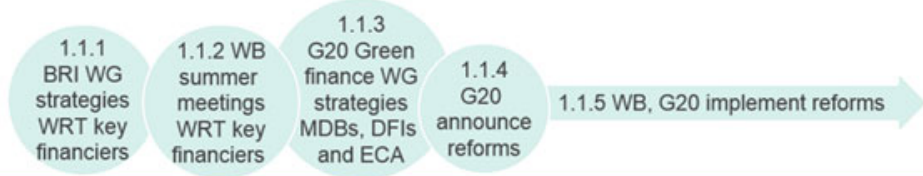

\section{$\begin{array}{llllllll}2018 & 2019 & 2020 & 2021 & 2022 & 2023 & 2024 & 2025 . .2030 . .2035 . .2040 . .2050\end{array}$}

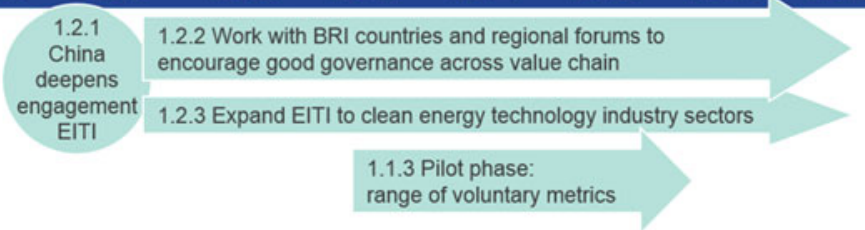

Fig. 43 Timeline of action plans under the strategic pathway: multilateral coordination of phasing down high-carbon FDI and development support, and enhancing best practice

other development actors towards both fossil fuels and clean energy technologies, with a clear and common roadmap for transition (the Asian Infrastructure Investment Bank could play a leading role in this). Committing to eliminate support for unabated coal projects could be a first step. At the same time: (ii) enhanced transparency and governance of energy infrastructure FDI could be achieved by implementing EITI and by expanding best practice in transparency and environmental and social good governance of investments in clean energy sectors (Fig. 43).

\section{(2) Increasing access to clean energy tech- nologies in developing countries}

Cooperation strategies with developing countries, MDBs and climate finance providers to increase access to clean energy technologies, through the provision of technology and investment packages, could be achieved by China and the BRI working with the EU, OECD Development Centre and IRENA. This cooperation strategy would work to: (i) support research on clean energy deployment requirements and innovative financing packages in developing countries. The BRI could also work via FOCAC and other regional forums to: (ii) establish regionally focused clean energy technology and investment packages, and deployment commitments. And: (iii) establish an international taskforce on financing Sustainable Development Goal 7 (access to affordable, reliable, sustainable and modern energy for all) including deployment commitments (perhaps linked to the G20 energy principles) - this would further strengthen the support of clean energy technology packages in non-BRI countries (Fig. 44).

\subsubsection{Risks and Obstacles}

While the alignment of FDI standards and strategies will entail significant political capital and time, working initially with bilateral or small groupings of MDBs, such as the Asian Infrastructure Investment Bank and major policy banks, could represent an initial achievable step. There is also great political and commercial sensitivity around payments between and to governments, complicating efforts to increase the transparency of fossil fuel and linked infrastructure investments.

\section{Security of Supply of Metals and Minerals for Future Energy Systems}

The accelerating deployment of low-carbon energy technologies - in particular, electric vehicle (EV) batteries - is resulting in rapidly increasing demand for metals and minerals such as lithium, cobalt, polysilicon and rare earth elements. Goldman Sachs estimates that for every $1 \%$ increase in the market penetration of EVs, lithium carbonate equivalent demand will increase by around half the current annual demand. 


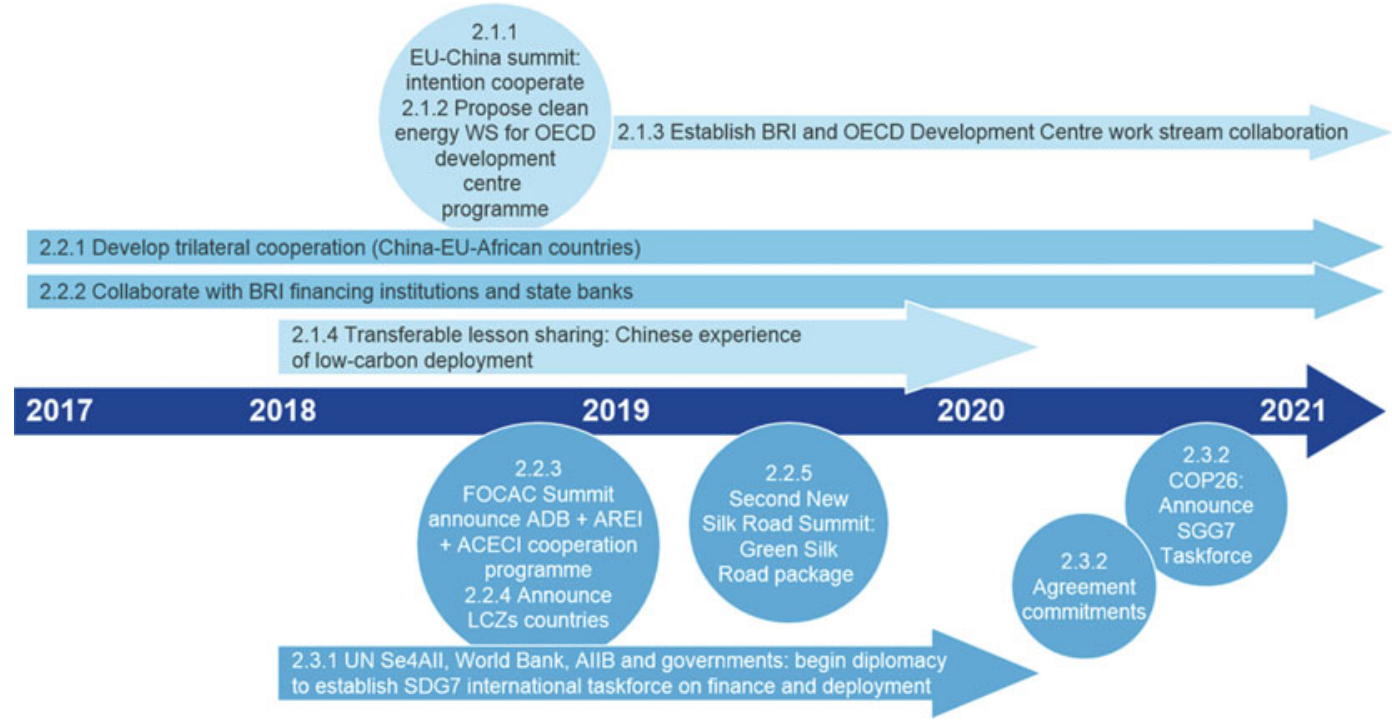

Fig. 44 Timeline of action plans under the strategic pathway: cooperation strategies with developing countries, MDBs and climate finance providers to increase access to clean energy technologies

Supply disruptions in metals and minerals markets have traditionally had less visible impacts on consumers than those in fossil fuel and food markets, for instance. As a result, they have received less attention from policymakers, and the regulation and data associated with these markets are generally considered national competencies. Compared to energy commodities, there is relatively little in the way of international governance and cooperation for metals and minerals markets. The market distortions of recent years-from anticompetitive practices such as export cartels to the imposition of unilateral export restrictions - have exposed many gaps in metals and minerals governance.

\section{Box 19: WTO limitations in resolving disputes over metals and minerals and energy resources}

While the WTO provides the main global institutional framework for coordinating and governing international trade, the trade in natural resources falls largely outside its remit. Separate chapters were included in the WTO texts to address issues related to agriculture and textiles, but not natural resources. Some regional agreements have tried to bridge this gap for energy, notably the Energy Charter Treaty and the North American Free Trade Agreement's energy chapter. Several reasons for the special treatment of natural resources in trade agreements have been cited:

1. the geographical distribution of natural resources is highly uneven and production is largely immovable;

2. the sovereign control of resource-endowed countries over their natural resources and their right to exploit them for economic and social development is recognised in international law;

3. trade in natural resources is often perceived as a key national security issue;

4. the extraction and consumption of resources produce severe negative externalities compared with most other traded products; and

5. a large proportion of resource trade takes place under long-term contracts, often through dedicated infrastructure 
such as pipelines or liquefied natural gas tankers.

The exhaustibility of natural resources, and the potential for infringements on national security, provide two potential justifications for trade restrictions under WTO rules, although these must be implemented in a non-discriminatory way.

In recent years, several key raw material suppliers have used export controls. Indonesia has introduced a ban on exports of unprocessed ores. Vietnam has also imposed restrictions on iron ore and copper, and export taxes have recently been debated in Brazil and India. In 2012, the USA, EU and Japan lodged complaints with the WTO over Chinese export quotas of rare earth minerals, and the quota system was withdrawn in late 2014. There have been various proposals for voluntary avoidance of export restrictions in times of crisis or extreme price volatility, which such restrictions tend to exacerbate.

With the shift from molecules to electrons, and the large-scale deployment of low-carbon energy technologies, new energy security concerns are emerging. First is the security of critical metals and minerals supply chains, and second is the availability of and access to new technologies in metals and minerals production, processing and recycling.

Many metals and minerals are important inputs to low-carbon energy technologies, but the extent to which they are critical depends on a variety of factors. Criticality is dependent on a commodity's importance to economic growth, combined with risks to supply shortages, and will vary between different consumer countries. Take the example of electric vehicles (EV); increasing EV uptake is of growing importance to China in terms of tackling urban air quality, but it is also critical to China's structural transition and its role as a leading country in high-tech industries, including EV manufacturing.

With EV sales likely to surpass 2 million per year by 2020, there are growing concerns as to how markets and supply chains will respond to increased demand for EV-critical metals such as lithium, cobalt, nickel and manganese. As these materials are difficult to substitute, governments are keen to safeguard against supply shortages. While no physical scarcity currently exists, supply risks are associated with the concentration of resources within a handful of countries and regions.

\subsection{Cooperation Opportunity}

Ensuring the security of metals and minerals for scaling up clean energy technologies will mean engaging with a range of new supply chains and producers. As the largest producer, consumer and trader of metals and minerals, and the largest manufacturer of renewable energy components, China is uniquely placed to lead on the establishment of multilateral metals and minerals institutions and policy processes. It also has the most to gain from stable markets; for example, a $1 \%$ shift in the price of iron ore could have cost China $\$ 800$ million in 2013.

Targeted outcome: Greater global coordination and cooperation on the supply and demand of critical metals and minerals help mitigate the risks of disruption to the deployment of clean energy technologies.

To achieve such an outcome, China could adopt two distinct strategic cooperation pathways:

(1) avoid supply-side shortages and trade disputes in the global supply chain of critical metals and minerals required for clean energy technology deployment; and

(2) minimise the need for additional extraction capacity by enabling countries to lower their dependency on the global supply of critical metals and minerals 


\subsection{Working with Key Partners to Achieve Cooperation}

Enhancing the governance of metals and minerals supply chains will mean forging partnerships with key players, some of whom are established partners and others newer partners. On the supply chain side, the China Chamber of Commerce of Metals Minerals \& Chemicals Importers \& Exporters could work with the European Commission and United States Geological Survey, both of which already maintain data and information on reserves and production.

Dialogues between producers and consumers will also be vital, China could encourage G20 states to engage constructively with regional forums, such as the Community of Latin American and Caribbean States (CELAC) and the Forum on China-Africa Cooperation (FOCAC). On the demand side, circular economy-based partnerships and breakthrough resource coalitions on secondary materials could reduce primary demand. China could work with the Clean Energy Ministerial and Mission Innovation to forge such partnerships.

\subsection{Rationale for Action}

By ensuring that the development and deployment of low-carbon technologies are not affected by supply chain disruption and shortages of critical inputs, both strategic cooperation pathways help facilitate improved urban air quality, as well as supporting China's progress up the manufacturing value chain. Ultimately, if a large part of China's development strategy is concerned with positioning itself as an exporter of batteries and EVs, its economic security will be closely linked to the security of the necessary raw materials.

Enhanced market cooperation and transparency could reduce international concerns over China's stockpiling of metals. At the production level, adherence to high standards of transparency and environmental and societal risk management can help reduce the risk of underperforming investments, particularly where the societal licence to operate is compromised by lack of investment in the host country, or labour and environmental violations.

From the perspective of China's partners, China's dominance in the production of rare earth elements makes it a critical partner in any efforts to reform the governance of metals and minerals markets. For China and its partners, fostering innovation and $R \& D$ into enhanced recovery, recycling and substitution helps diversify supply and increase substitution. Developing substitute technologies is aligned with China's domestic ambitions to enhance $R \& D$ capacity and develop new business models.

\subsection{Strategic Pathways}

\section{(1) Avoiding supply shortages and trade disputes}

Supply chain shortages and trade disputes could be avoided by China working with partners to develop: (i) improved information, data and price transparency across the supply chain, while also: (ii) supporting dialogues and developing win-win technology and investment packages with existing, new and emerging producers to support trade and prevent export controls. Resolution of trade disputes that do arise would require China to work with major economies to reaffirm their commitment to WTO rules and dispute resolution mechanisms, while working long term to address gaps in rules around the trade of raw metals and minerals (Fig. 45).

(2) Reducing the demand for increased production

Minimising the need for additional extraction capacity could be achieved by: (i) accelerated $R \& D$, innovation and deployment of enhanced recovery and recycling of metals and minerals from in-use stocks, enabling the greater use of secondary materials. This could be led by a Clean Energy Ministerial breakthrough resources coalition, including industrial partners and national bodies. There should be greater focus on future plans for 


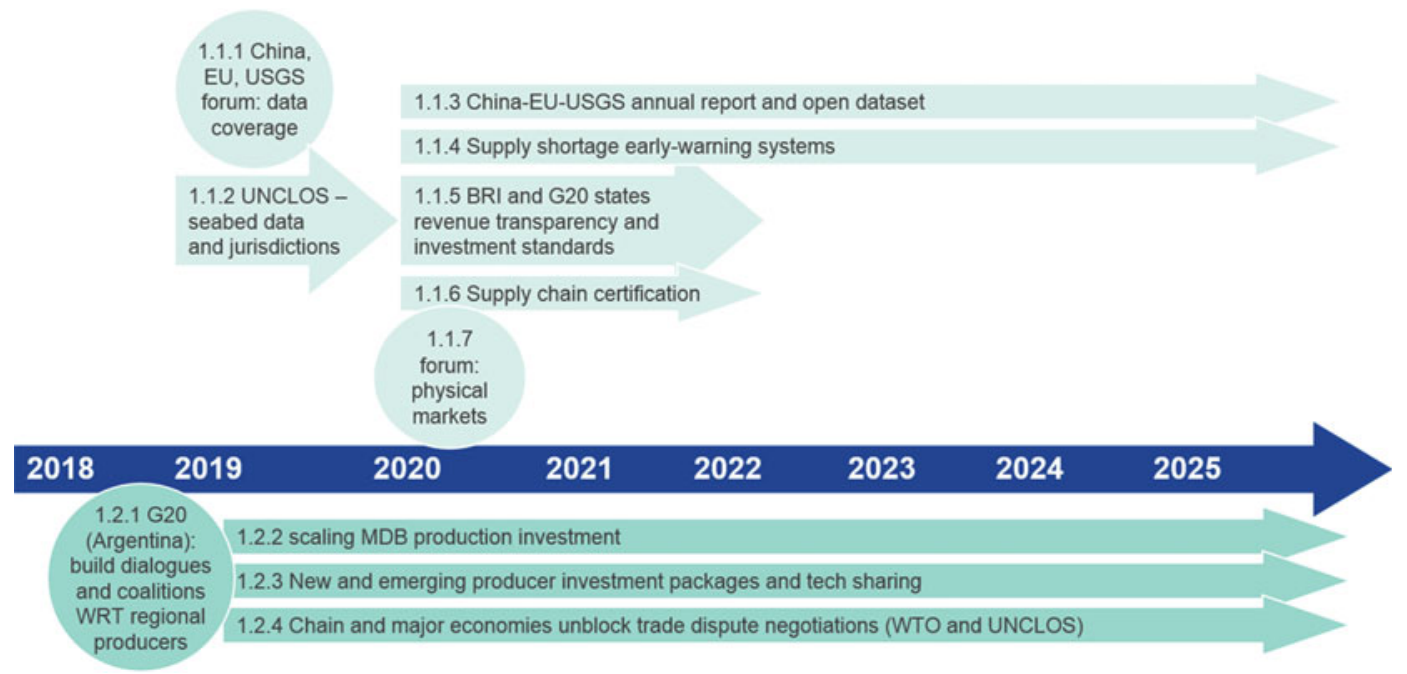

Fig. 45 Timeline of action plans under the strategic pathway: the avoidance of supply-side shortages and trade disputes in the global supply chain of critical metals and minerals required for low-carbon technology deployment

accelerating such R\&D. China's circular economy strategy could also help reduce its long-term import needs for these critical materials. Reducing reliance on critical metals and minerals could be furthered by forming unconventional alliances with regional neighbours, including the EU and Japan, to support: (ii) R\&D and piloting of substitution technologies for those low-carbon energy technologies most dependent on critical metals and minerals (Fig. 46).

\subsection{Strategic Direction of Travel}

For many critical metals and minerals, the concentration of production within specific regions and countries, facilitates the possibility of this strategy being achieved with multiple bilateral dialogues. However, the growing number of countries deploying clean energy technologies at scale naturally expands the number of nations with an interest in the stable supply of critical metals and minerals. So, while the centre of gravity in these dialogues and market reform

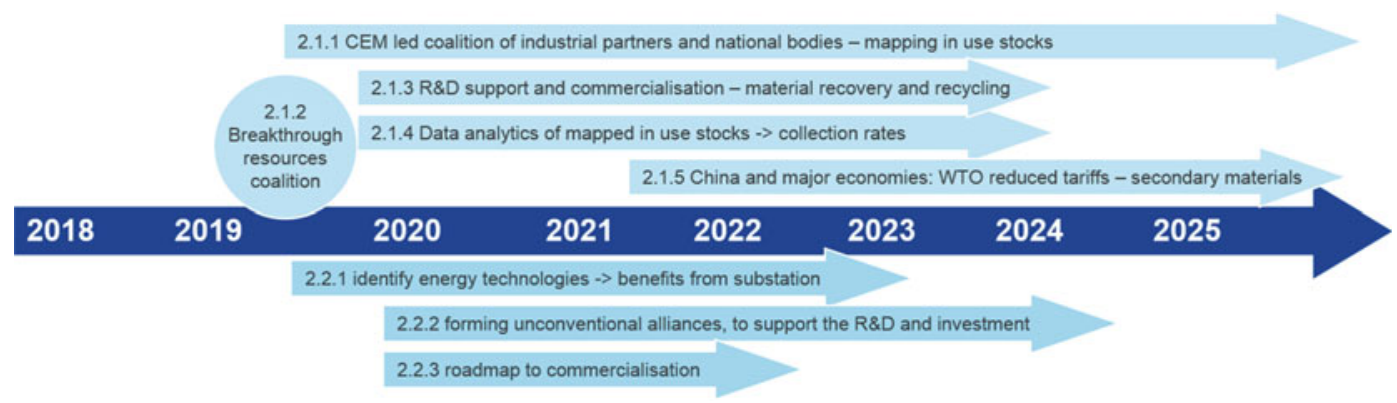

Fig. 46 Timeline of action plans under the strategic pathway: minimising the need for additional extraction capacity by lowering the dependency of countries on critical metals and minerals 
mechanisms sits with China, should China choose to pursue this strategy of utilising multilateral platforms and regional forums, it is likely to deliver greater win-win and optimal outcomes for all countries.

\subsection{Risks and Obstacles}

Data sharing on metals and minerals markets is politically challenging, not least because of its links to both national security and financial markets (where stockpiles and metal warehousing are concerned). However, if China chose to take a lead in this area, this could increase trust and demonstrate a commitment to greater transparency. Progress has been possible in other, arguably more sensitive, areas such as energy and food.

At the same time, relatively little governance architecture exists at present, so there is minimal risk of disrupting or undermining international norms. Relatively low prices take some of the heat out of metals and minerals markets and provide political space for governance reforms. China already has strong trade and investment links with Australia, Argentina, the Democratic Republic of the Congo and Chile-although these will require sensitive management as the geopolitics of individual players on the supply side shifts, and as international competition for access to resource contracts increases.

\section{Electricity Reliability During the Shift from Molecules to Electrons}

The pace at which solar photovoltaic, wind and electric vehicle battery pack prices keep falling is accelerating the fundamental shift of the energy transition-from molecules to electrons.

As early as 2014, onshore wind delivered electricity in Europe at $\$ 50$ per megawatt-hour (MWh) without subsidies, compared to \$45140/MWh for fossil fuel power plants. The trend of renewables becoming increasingly cheaper than fossil fuel generation across jurisdictions is clear. In China, both solar and onshore wind's levelised cost of energy is likely to be cheaper than coal and gas by 2028 (both are already cheaper than gas power stations). In Germany, solar and onshore wind are already cheaper than coal and gas; in the USA they are likely to become cheaper as early as 2024 . It is therefore no surprise that renewables have increased their share of global new capacity additions from $8.5 \%$ in 2002 to $42.6 \%$ in 2015.

One of the principal solutions for achieving security of supply or balanced electricity systems with a high penetration of renewables, while reducing curtailment, is the increased trade of electricity through power interconnectors. While high voltage cross-border interconnector capacity is expanding rapidly-growing by $81 \%$ in the 10 years up to 2015 - and is likely to double by 2025, China, and Asia as a whole, has limited interconnection to its neighbours, relative to its renewable power generation. In Europe, around $23 \mathrm{MW}$ of interconnection capacity exists per GWh of renewable generation, whereas China's interconnection to Russia is equivalent to $3 \mathrm{MW}$ per GWh. ${ }^{3}$ Based on announced and planned projects, this will rise to $9 \mathrm{MW}$ per GWh. More interconnections in China would reduce wind $(17 \%)$ and solar (10\%) curtailment and stem the rising amount of hydropower dumped in Sichuan and Yunnan provinces-142 and 314 TWh respectively in 2014 - a fivefold and sixfold increase on the previous year.

EV penetration rates are also set to increase dramatically. In 2016, EV sales grew by $55 \%, 20$ times greater than internal combustion engine (ICE) vehicles. EV lithium-ion battery costs have collapsed by three-quarters over the past six years, with a further $30 \%$ reduction likely by the end of the decade as global manufacturing capacity looks set to increase sixfold by $2020 .{ }^{4}$ The point at which the total cost of running an EV reaches parity with ICE vehicles is widely expected in the next decade or so. By 2040, Bloomberg New Energy Finance (BNEF) expects EVs to account for more than half of all new vehicle sales and a

\footnotetext{
${ }^{3}$ Chatham House calculations.

${ }^{4}$ Relative to 2016 , based on company announcements.
} 


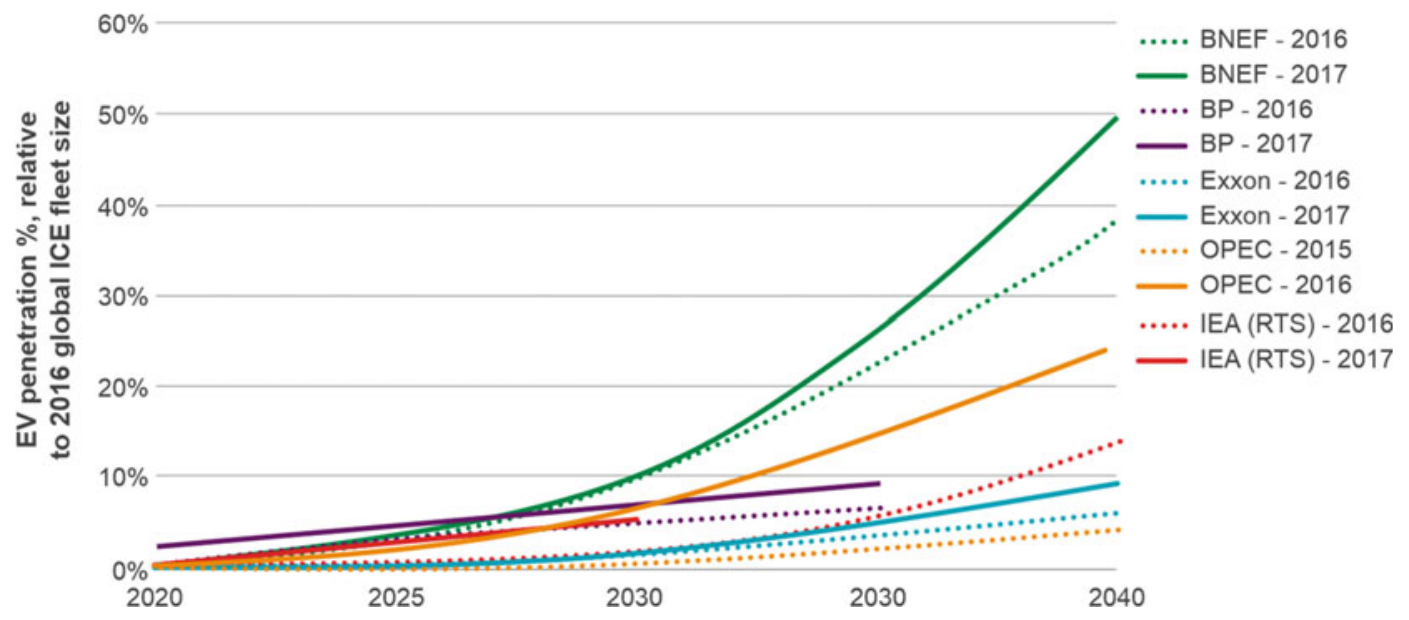

Fig. 47 Various forecasts of global EV fleet size as a percentage of 2016 ICE fleet size, and how those forecasts have increased over the past few years

third of all vehicles on the road. Goldman Sachs forecasts a global fleet of 83 million EVs by 2030. Even OPEC more than quadrupled its forecast between 2015 and 2016 to 266 million EVs globally by 2040 (Fig. 47).

Unless the expansion of EV charging infrastructure is staggered, the market penetration of EVs will reach limitations as inadequate grid reinforcement and increased peak demand will compound the difficulties of maintaining reliability of electricity supply. In the UK, the National Grid forecast of 9 million EVs by 2030 would increase electricity demand by around $8 \%$. However, peak demand would increase by around $13 \%$ if charging is not staggered. Smart staggered charging requires two-way communication, which isn't currently built into standard EV charging points (Fig. 48).

\subsection{Cooperation Opportunity}

As the largest renewables and EV battery manufacturer and generator of renewable power in the region, China could take the lead in cooperation and governance reforms to facilitate cross-border electricity integration. The BRI could provide a suitable forum for cooperation.

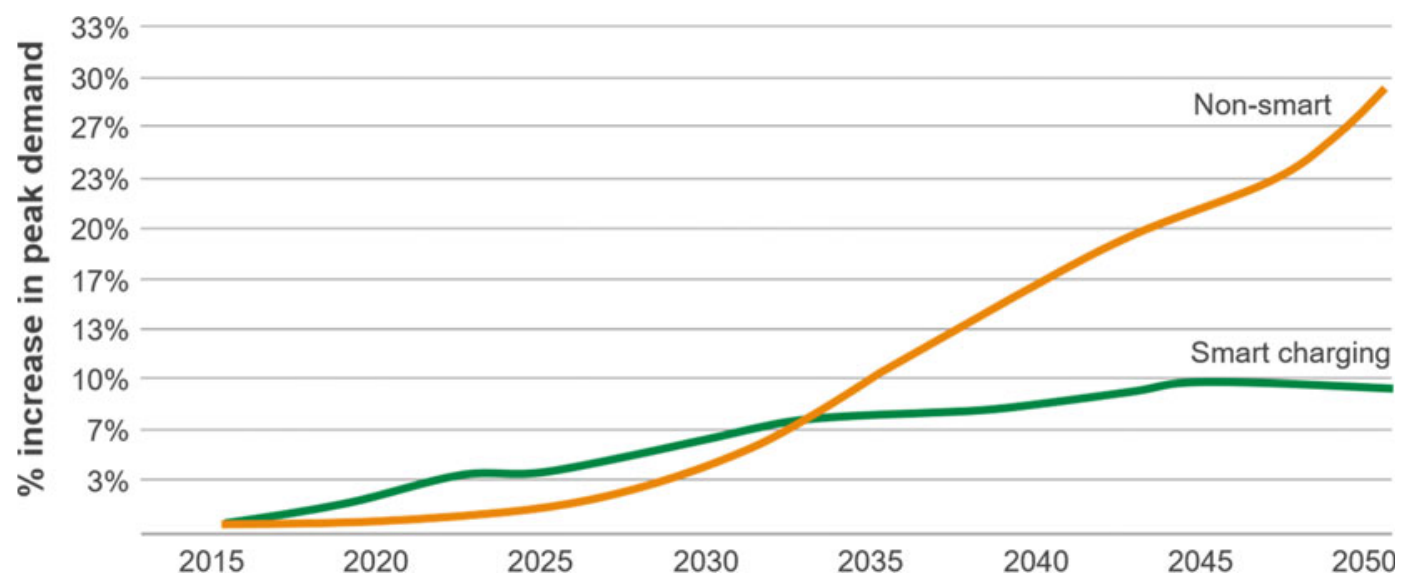

Fig. $48 \mathrm{eV}$ peak electrical demand in the UK, depending on adoption of smart charging 
Targeted outcome: Regional electricity systems capable of integrating high penetration of renewables, and the use of surplus power, while connecting millions of electric vehicles.

In order to achieve such an outcome, the complexity of connecting electricity systems across borders via interconnectors requires governments to take the lead in several areas. China and its regional partners require harmonised national electricity markets to trade electricity effectively through interconnectors. The avoidance of stranded assets and ensuring the future connection of high renewable supply with high demand regions requires regional planning to avoid lock-in and lock-out. Further, as electricity markets become increasingly interconnected the risks of cyberattack are best mitigated by strengthening regulations across jurisdictions.

Staggered smart EV charging, such that demand is spread over the evening when drivers return home to flatten and reduce peak demand, requires international standardisation of charging infrastructure. Scaling up the deployment of lithium-ion stationary battery storage requires alignment of investment strategies towards lithium-ion.

To achieve such an outcome China could adopt two distinct strategic cooperation pathways:

(1) regionally connected, coordinated and secure electricity markets enabling cross-border trade of electricity through interconnectors; and

(2) international cooperation to accelerate smart management of EV electricity demand and vast deployment of cost-effective electricity storage.

\subsection{Strategic Regional Forums to Drive Reforms}

The BRI could provide a platform for the regional planning of interconnectors, as well as working with international partners to learn and implement crucial lessons in the electricity market reforms required to connect electricity markets effectively. Working in partnership with
ASEAN Plus Three could enable greater participation and buy-in from regional partners. On EV charging and deployment of affordable storage, IRENA is well placed to host a China-led initiative to drive the agenda internationally.

\subsection{Rationale for Action}

While both strategic pathways facilitate the shift from molecules to electrons-improving air quality and maintaining reliability of electricity supply - further benefits, or win-wins, for China and its international partners can be identified.

China can benefit from opportunities to export surplus electricity and reduce electricity costs through grid interconnection and balancing: regional electricity trade saves consumers money and decreases capacity margin requirements for China and its partners. Cooperation on energy interdependence can build trust among partners, creating wider benefits.

Internationally standardised smart EV charging stations reduce all countries' EV deployment limits by lowering peak demand, while removing limits to interoperability between various EV and charging infrastructure manufacturers - enabling China to export more EVs. Further, China and its partners benefit mutually from the reduced need to strengthen grid capacity and the increased potential this allows for more renewables. Lower EV integration limits improve air quality in cities, which is especially important for China, while reduced EV import costs benefit China's partners.

As the global leader in lithium-ion, solar photovoltaic and wind turbine manufacturing, China will benefit from increased exports.

\subsection{Strategic Pathways}

(1) Regional cross-border trade of electricity China could use the BRI to establish two multilateral clubs that would work in parallel to enable interconnector-facilitated crossborder trade of electricity. This may be more effective working in partnership with the ASEAN Plus Three forum. The first club 


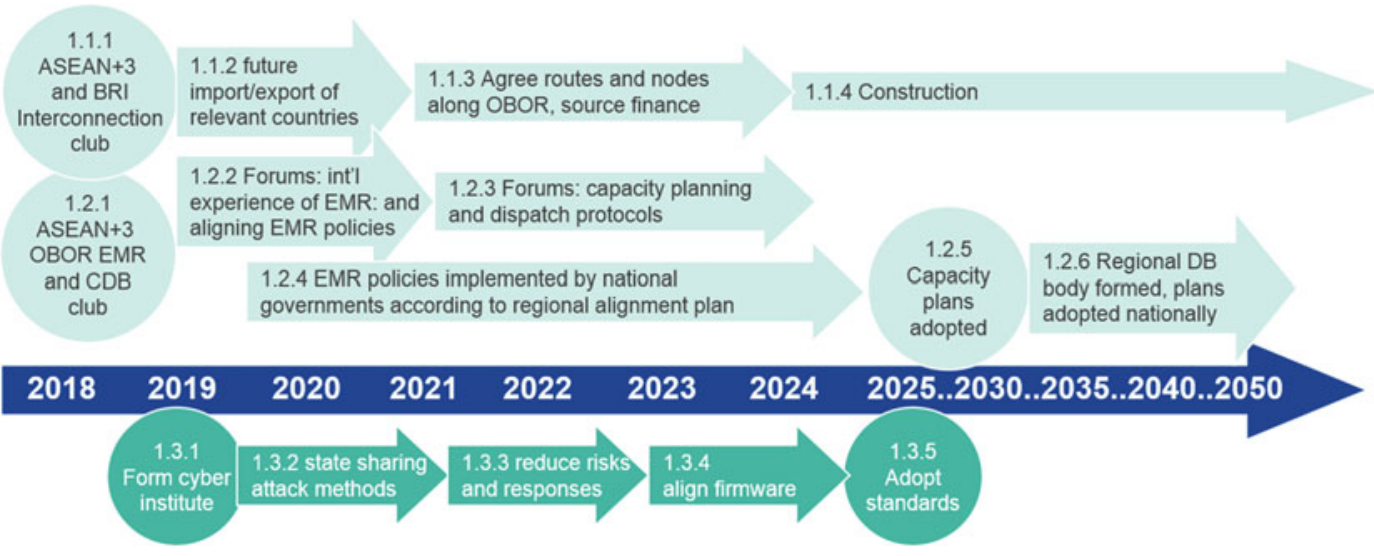

Fig. 49 Timeline of action plans under the strategic pathway: regional cross-border trade of electricity

would focus on the planning and construction of mutually beneficial interconnectors. The second club would focus on the alignment of regional national electricity market reforms (EMR), leading to the coordination of regional capacity, dispatch and balancing (CDB). China could simultaneously work with G20 states to form a grid cybersecurity multilateral to ensure the security of increasingly interconnected electricity systems (Fig. 49).

(2) Smart EV charging and cost-effective electricity storage

China could work in partnership with the International Renewable Energy Agency (IRENA) to achieve international coordination and standardisation of smart EV charging stations and the global alignment of electricity storage investment towards lithium-ion batteries (Fig. 50).

\subsection{Risks and Obstacles}

China's partners could be unwilling to lock themselves into dependency on Chinese electricity exports, particularly given local opposition to interconnector routes. Further, there may be opposition to the greater remit and power of ASEAN Plus Three and BRI in planning interconnector routes, compounding the fact that both currently lack the technical expertise. As such, the most politically feasible option would be to connect high demand and low supply regions within China.

Regarding electricity market reforms (EMR) and capacity, dispatch and balancing (CDB), regional differences in phases of EMR and political willingness to align reforms may prove difficult to overcome, especially given that national regulators currently lack enforcement capability and capacity. Given this, a stepped

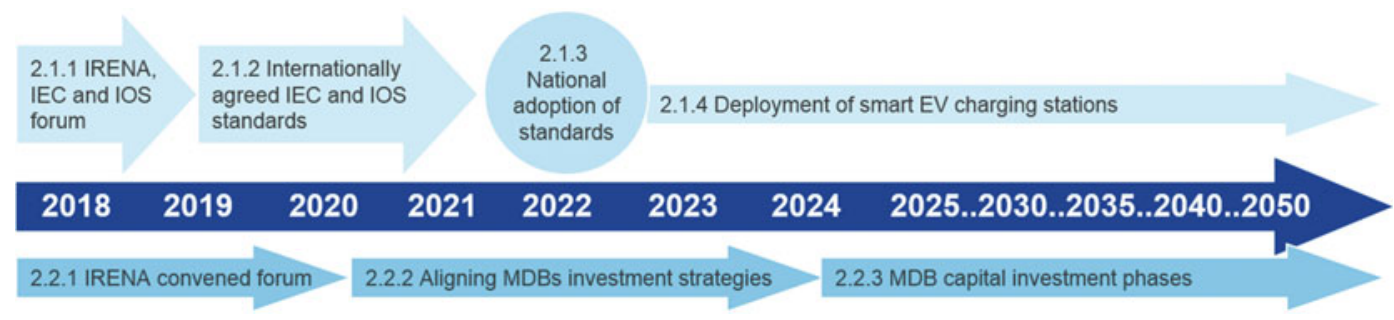

Fig. 50 Timeline of action plans under the strategic pathway: smart EV charging and deployment of cost-effective electricity storage 
approach to EMR could be adopted, such that the benefits of incremental reform are tangible to each partner country.

Cooperation on internationally coordinated grid cybersecurity requires a high degree of trust between states, as well as between states and corporations, and has proven elusive so far, though this is not a precondition for cooperation on grid interconnection.

\section{Conclusions}

This paper has explored in detail four cooperation options that China could pursue to help facilitate the shift to a low-carbon, secure energy system - a system based on quality, both on the supply and the demand side, rather than quantity. From this follows several observations:

\section{International Cooperation is Critical to Achieving Chinese and Global Energy Objectives}

The global challenge of enhancing energy security over the course of the next half century while decarbonising the energy sector will not be achieved through governments acting unilaterally in isolation to one another. Energy securitywhether of oil and gas supply or the reliability of (increasingly interconnected) electricity gridswill be greatest when governments have shared rules for how markets are governed during normal operation and, critically, disruption. Such frameworks build trust, reduce system costs and mitigate the risk of market failures should disruptions occur. Similarly, the costs of decarbonisation can be minimised through cooperative actions and arrangements to align standards, avoid carbon leakage and extend carbon pricing, and maximise aggregate demand for low-carbon technologies. Nor can the two objectives - energy security and decarbonisation - be considered in isolation: each has implications for the other.

\section{There Is No Silver Bullet Governance Reform or Cooperation Strategy}

This paper has expanded on four opportunities for international cooperation. There are several others that could be explored. It is clear that intergovernmental cooperation and governance reforms will be needed in many different areas. A country can pursue international cooperation along a spectrum of interventions, ranging from simple pragmatic bilateral approaches to bolstering regional mechanisms and ambitious multilateral reform agendas with higher risks of failure but potentially larger returns. Different approaches will often be mutually reinforcing and form distinct parts of an overall strategy: the opportunities for cooperation considered in this paper include different mixes of bilateral, regional and multilateral elements.

\section{The Prize for All Countries Is Substantial}

A country's dominance in specific areas of low-carbon manufacturing, and its ambition to extend this to new green technologies, means it can benefit from emissions reduction efforts in other countries, which will increase demand for its exports. Establishing strong governance of critical metals for low-carbon manufacturing, on which China's export base will increasingly depend, is important for China's long-term economic security. As the world's largest energy consumer and importer, China has a strong interest in establishing effective governance for fuel security and grid interconnection. China's energy security will depend on successful global efforts to limit climate change, so supporting other countries' transition is likely to be a priority.

4. Win-Wins Are Available, but Will Require Compromise

The international community has a shared interest in collective energy security and low-cost decarbonisation, creating opportunities for win-win cooperation. However, political compromises will often be needed to move forward. For example, expanding IEA membership will require concessions from existing member countries, but also from China and other emerging economies, to improve data transparency and agree to emergency sharing rules. 


\section{G20: Challenge and Opportunity}

The G20 offers a potential avenue through which China and partner countries can pursue reforms. Its membership has critical mass in key areas such as emissions, energy consumption and investment and R\&D, as well as workstreams in relevant areas such as infrastructure, green finance, investment and fossil fuel subsidies. It also has a track record of reforming international organisations and establishing new ones. However, the G20 also presents significant challenges, not least a lack of institutional capacity and focus. In the short term, the largest challenges may be political, with the current US administration unlikely to support many of the reforms explored in this paper.

\section{Belt and Road Initiative: A Platform for Cooperation}

China's Belt and Road Initiative (BRI) provides various opportunities for cooperation with partner countries: on energy security, possibly through the Energy Charter Treaty (ECT); on low-carbon energy and infrastructure, in partnership with multilateral development banks; and on electricity network integration. China is capable of building formal governance structures associated with the BRI. But it will need to consider the opportunity cost of creating new governance arrangements in the BRI (instead of at the global level) and the appetite of BRI countries to agree new governance arrangements beyond the existing ones they participate in (e.g. ECT, IEA, ASEAN Plus Three).

\section{China's Strategic Path}

Ultimately, how China seeks to pursue enhanced cooperation is a strategic question for China. At one extreme, China could adopt a pragmatic, transactional approach based on bilateral deals with one country after another. At the other extreme, China might seek to pursue its objectives through multilateral institutions. There are pros and cons to each-for example, while individual bilateral deals may be easier to make, they might not provide global goods and could become too numerous to manage effectively. On the other hand, multilateral approaches may be better suited to providing global goods but can take a long time to negotiate or reform.

Plotting the different cooperation options considered above on the matrix presented in the introduction is revealing (see below) (Fig. 51).

While the options span a range of market- and policy-led approaches, very few are based on a transactional approach. Instead, the proposals cluster among regionalism and multilateralism, in the form of efforts to establish, strengthen and promote common rules and norms.

\section{China's International Energy Cooperation and Strategies}

China has become the world's second-largest economy, with sustained and rapid economic development and continuously growing national strength, since its reform and opening up began in 1978. With its growing economy, China's demand for energy is increasing, turning it into a country with high levels of energy production, consumption and trade, as well as an increasing dependence on foreign energy.

China is also becoming a leader in global energy technology deployment. China's development has had a significant and far-reaching impact on the global energy landscape. Influenced by world politics, the global economy and technological revolution, the international energy landscape displays new features and changes and brings new opportunities and challenges to different countries. It is difficult for any one country to address critical energy issues on its own. The question of how to reform global energy governance and guarantee every country's energy interests through international cooperation has become a major issue for China and other 


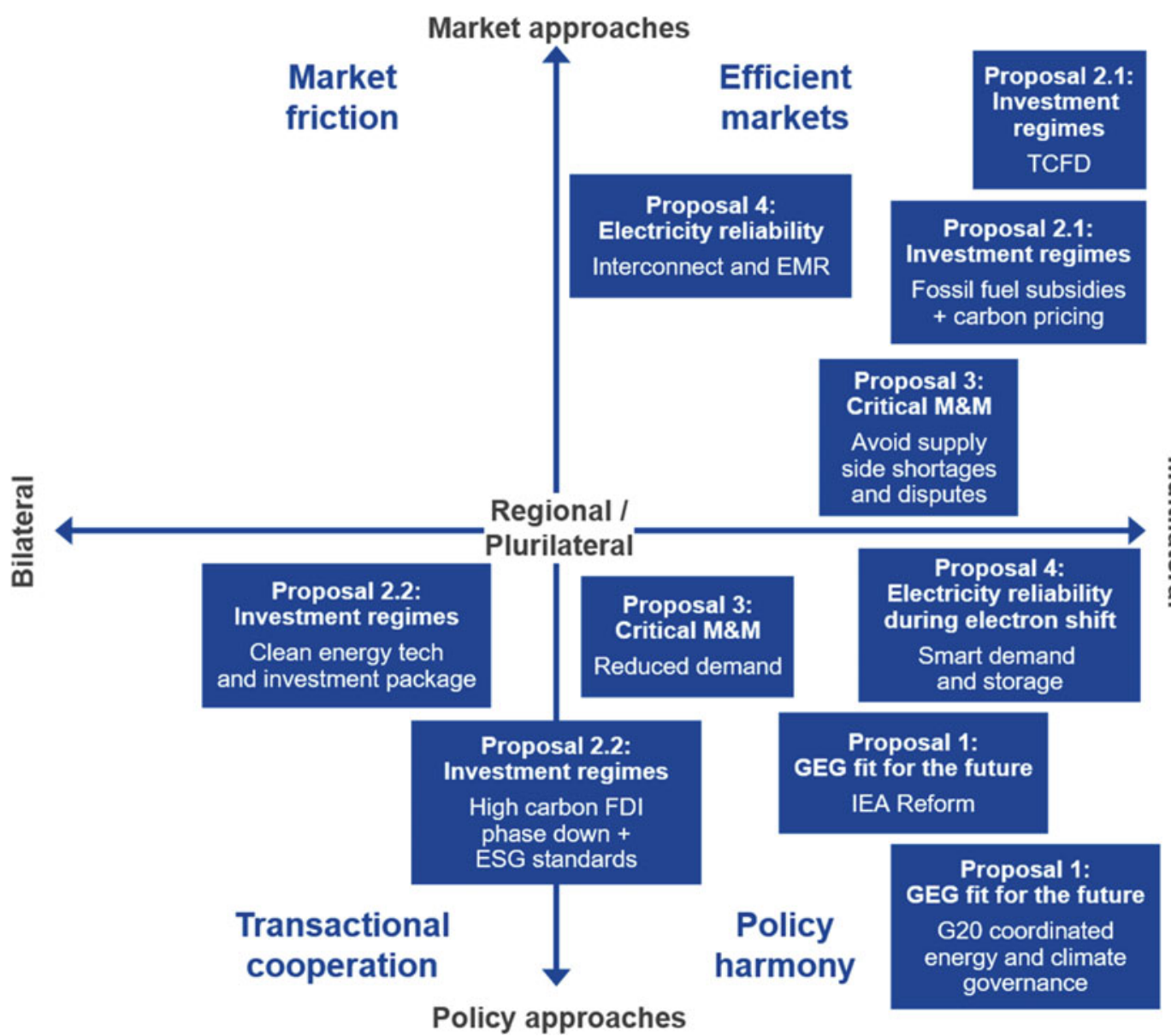

Fig. 51 Each international energy cooperation and governance opportunity placed within the spectrum of unilateral to multilateral and policy-led to market-led approaches

countries in this new era. How China builds international cooperation strategies and better participates in global energy governance is not only related to its own development but to that of the world as well.

\subsection{China's Relations with Major Energy Trade Partners}

As China's economic output increases, its demand for energy grows as well. International energy trade - an important way to meet energy needs-plays an increasingly important role globally. As China's dependence on foreign energy will not change in the short term, the importance of its energy imports far outweighs that of its exports. Energy trade will play a significant role for some time to come and be an important driver for domestic economic growth. Rising energy dependence means that the international energy landscape has more and more impact on China's economic growth and energy security. China's relations with its major energy trading partners, including Russia, the Middle East, Central Asia, the USA, ASEAN and Latin America, are therefore crucial. 


\subsubsection{Russia}

Energy exports are an important industry that shore up the Russian economy. Before 2011, Russia's oil and gas exports to Asia-Pacific countries accounted for only 3\% and 5\% respectively of its total hydrocarbon exports. The US and European economic sanctions against Russia accelerated its energy cooperation with Asia-Pacific. With their agreement on joint energy cooperation, China and Russia established extensive cooperation in oil, natural gas, nuclear power, electric power, coal and other areas. Russian oil is mainly transported by sea, rail and pipeline to China. As China borders on Russia, road and pipeline transport are the most cost-effective and safest ways of trading oil and natural gas. The China-Russia Energy Cooperation Committee (formerly the Energy Negotiation Mechanism at Vice Premier Level) established a new high-level platform for China-Russia energy cooperation.

Energy cooperation between China and Russia focuses on oil trade. In 2015, China became the largest buyer of Russian oil. According to China's General Administration of Customs, in 2016 Russia replaced Saudi Arabia for the first time as China's largest supplier of crude oil. In 2016, China imported 381 million tonnes of crude oil, an increase of $13.57 \%$ over the previous year, and its imports from Russia rose by almost $25 \%$ to 1.05 million barrels per day. China-Russia energy investment and technology cooperation has been upgraded from direct trade to joint exploration, joint development and benefit-sharing, cooperation across the value chain, and from upstream to downstream areas. By way of new joint ventures and share acquisitions, China has been gradually participating in Russia's crude oil refining, refined oil product processing, liquefied natural gas processing, oil and gas sales and other areas. In the future, China will expand into fields like technology research and development, equipment manufacturing and engineering services.

\subsubsection{Middle East}

The Middle East comprises 17 countries, including Saudi Arabia, the United Arab
Emirates, Iran, Iraq and Israel. It is an important hub between the west and the east and a point where the Silk Road Economic Belt and the 21st Century Maritime Silk Road meet.

China-Middle East energy cooperation is one of the keys to China's energy security. As China's economy and energy demand grow, energy cooperation will be one of the most strategic areas in China-Middle East relations.

China started to import petroleum and related products from the Middle East in the 1990s. Gradually, the Middle East became China's largest source of oil imports. From 1996 to 2009, China's crude oil imports from the Middle East accounted for $45-50 \%$ of China's total oil imports. In 2011, China imported about 130 million tonnes of crude oil from the Middle East, accounting for more than $50 \%$ of total imports that year. In 2013, imports reached 146.54 million tonnes or $52 \%$ of total imports. In 2014, crude oil imports from the Middle East increased to 171.7 million tonnes, which was $46 \%$ of the total.

Cooperation on oil and gas between China and the Middle East countries has made remarkable progress. CNPC, Sinopec and CNOOC have developed many large oil field projects in Iran and Iraq. In particular, China-Iran oil and gas cooperation has great potential in dozens of large oil and gas fields, and in auxiliary project construction, engineering and technical services. In addition, China also cooperates with Middle East countries on training in clean energy.

The Belt and Road Initiative offers valuable opportunities for cooperation between China and the Middle East. Responding to the initiative and strengthening the cooperation with China will help Middle East countries develop their domestic economies. In addition, the region's petroleum exporting countries depend more on the Chinese market during low oil price cycles, which makes cooperation even more attractive.

\subsubsection{Central Asia}

The five countries of central Asia (Kazakhstan, Turkmenistan, Uzbekistan, Kyrgyzstan and Tajikistan) are a hub for the Silk Road Economic 
Belt. They have been an important economic corridor linking China with Western Asia and Europe since ancient times.

Central Asia has abundant oil and gas reserves, ranking third in the world after the Middle East and Russia. More than $70 \%$ of its crude oil output is exported. In 2015, Kazakhstan produced 85.6 million tonnes of crude oil, of which more than 70 million tonnes went to other countries; Turkmenistan produced 74.16 billion cubic meters of natural gas and exported more than 50 billion cubic meters. Since 2000, China and Central Asia have been deepening their cooperation in oil and gas trading. Now, China is Kazakhstan's third-largest oil importer, and Uzbekistan's and Turkmenistan's largest gas importer. At the end of the 12th Five-Year Plan (2011-15), China's oil and gas imports from Central Asia accounted for $1.85 \%$ and $48 \%$ respectively of its total oil and gas imports. Thanks to Central Asia, China's overseas energy supply structure has been optimised. China's main imports from the Central Asian countries are primary energy products. In 2014, for example, China's oil and gas imports from Central Asia accounted for $34 \%$ and $36 \%$ respectively of its total imports from this region. At the same time, China exports to Central Asia processed energy products and manufactured goods, such as oil country tubular goods, petroleum machinery and chemicals, which made up $4.91 \%, 5.15 \%$ and $3.52 \%$ respectively of China's total exports to Central Asia. China has built power transmission links and substations, thermal power plants and other projects for Kyrgyzstan, Uzbekistan and other Central Asian countries.

In addition to energy trade, China's cooperation with Central Asia's energy industry is also developing from upstream energy exploration and production to cooperation along the entire value chain. Future cooperation will prioritise downstream industries, such as petroleum refining and petrochemicals. In the future, it will be further extended to energy-related industries like petroleum equipment manufacturing and production services.

The long-term energy cooperation between China and the Central Asian countries is based on mutual trust. The Belt and Road Initiative provides a new platform and opportunities for diversification. The Central Asian countries can expand into and build energy export markets in North-east Asia, South Asia and the Pacific Rim countries.

\subsubsection{USA}

The USA and China are the world's largest energy producers and consumers. The two countries regarded energy as one of the important cooperation areas in 1979 when they established diplomatic relations. Over the past 40 years, despite differences and obstacles, China and the USA have been expanding and deepening energy cooperation and made great progress. Especially in the 21st century, the USA's energy independence strategy offers an unprecedented opportunity for China-US energy cooperation against the background of energy and economic globalisation. The two countries have enormous potential for cooperation in areas like natural gas, nuclear power and renewable energy.

Bilateral and multilateral energy cooperation mechanisms - like the APEC Energy Working Group, the Asia-Pacific Partnership on Clean Development and Climate, and the Carbon Sequestration Leadership Forum-strengthen China-US cooperation in the energy sector. From 2004, China-US energy policy dialogue became an important communication channel for the two governments and a platform for the two countries' energy sectors to discuss topics like energy trends, energy efficiency, resource and environmental protection. The U.S.-China Oil and Gas Industry Forum - co-hosted by China's National Energy Administration, the U.S. Department of Energy and the U.S. Department of Commercehas been actively promoting the two countries' cooperation in oil and gas.

In 2008, the U.S.-China Ten-Year Framework for Cooperation on Energy and Environment was signed during the fourth China-U.S. Strategic Economic Dialogue, making energy cooperation the focus of the conference for the first time.

\subsubsection{South Asia and ASEAN}

South Asia covers eight countries, including India, Pakistan, Bangladesh and Sri Lanka. Five of the eight countries share a border with China. 
Bangladesh, Sri Lanka and the Maldives are on the Maritime Silk Road. South East Asia, which is part of the BRI's China-Indochina Peninsula Corridor, is a strategic channel between China and the Indian Ocean.

China has obvious advantages in the field of energy development and equipment manufacturing, as well as strong technical strength in terms of coal exploitation and renewable energy, including hydropower. Energy cooperation between China and ASEAN countries has a good foundation. At present, China Southern Power Grid (Yunnan and Guangxi) is interconnected with the power grids in Laos, Myanmar and Vietnam, and industries like power transmission, power exchange and transnational meter reading have been developed. Power trading is beginning to take shape. China Southern Power Grid started to transmit power to Laos in 2009, and Thailand purchases electricity from Yunnan via Laos. In October 2008, six $100 \mathrm{MW}$ power generating units at Shweli River Hydropower Station, Myanmar's largest hydropower build-operate-transfer (BOT) project, were integrated with China Southern Power Grid and started to transfer power to China. Electricity has gradually become a new growth point in China's trade with ASEAN countries.

Cooperation in power investment between China and ASEAN countries continues to evolve. In recent years, companies like State Power Investment Corporation, China Huaneng Group, China Guodian Corporation, China Huadian Corporation, China Datang Corporation and China Three Gorges Corporation work with ASEAN countries to develop power resources. For example, the companies have built hydropower stations and coal-fired power plants on a BOT basis in Laos and Vietnam; and State Grid Corporation of China jointly operates the Philippines' power transmission network.

In 2015, China's power companies invested $\$ 317$ million in the 10 ASEAN countries in projects of more than $\$ 30$ million, and $\$ 4.63$ billion in engineering, procurement and construction (EPC) projects of more than $\$ 100$ million. Overall, China and the ASEAN countries have a large trade volume of energy products and energy equipment. Energy products mainly include crude oil, natural gas, coal, coke and refined petroleum products; energy equipment is both imported and exported, including complete equipment packages for thermal power plants and hydropower stations, equipment for nuclear power plants, and new energy generation equipment for wind and solar power. The China-Myanmar oil and gas pipelines interconnect China with ASEAN. They act as an energy channel for China to the Indian Ocean and play an important role in diversifying China's oil and gas imports. In addition, China cooperates with Thailand on marsh gas, solar photovoltaic and biomass power.

\subsubsection{Latin America}

Oil and natural resources in Latin America are abundant but underexplored and underdeveloped. This brings opportunities for energy cooperation and labour export between China and Latin America.

Latin America is one of the first destinations of China's Go Out strategy. However, resource nationalisation in Latin America and geopolitical implications from the USA have hindered energy cooperation between China and Latin America. Rising international oil prices make Latin America more eager to shake off US control and strengthen cooperation with China in finance, technology, infrastructure and other sectors.

At present, China's cooperation with Venezuela, Brazil, Peru, Ecuador and other Latin American countries focuses mainly on energy trade, oil and gas, engineering and technical services, and labour export. It covers fields like exploration, exploitation and refining of oil and gas resources, and pipeline construction. Latin American countries need a great deal of investment in oil and gas exploration and development and engineering and technical services. In the future, China and Latin America will deepen their cooperation in those fields and in new energy as well. 


\subsection{Problems and Challenges Facing China's Future International Energy Cooperation}

International energy cooperation is an important means to improve energy security and promote sustainable energy development in all countries. Energy cooperation enables a single country to reap benefits that it cannot acquire alone. It is therefore important that China and other countries cooperate to safeguard their energy interests through multilateral partnerships and multi-level international cooperation mechanisms.

China's international energy cooperation is faced with a series of real and potential problems and challenges.

\subsubsection{Problems}

First, most of China's international energy cooperation is through dialogue or general cooperation. China mainly joins organisations that are established for coordination or dialogue, but rarely joins alliances or organisations subject to laws or regulations. Due to its membership in only a few international energy cooperation organisations, China has a low level of international cooperation. At the regional level, China participated in more cooperation organisations with legally binding agreements. In the Asia-Pacific region, although China plays an important role in international organisations (such as APEC, Shanghai Cooperation Organisation and ASEAN), energy cooperation in this region, especially in East Asia (including South East Asia and North East Asia), lacks the legal and institutional framework and relevant energy cooperation organisations.

Second, China's overseas energy investment is still at an early stage. In oil, China is gradually developing from a small- to a large-scale investor and is broadening the scope of its investments. These include oil field production management and technical services, oil field development, engineering and construction, risk exploration, oil trade, equipment export, and oil and gas asset acquisition.
Third, China does not have pricing power in the international energy market. Lacking control and influence, China has been disadvantaged in international energy competition for a long time, so it can only passively accept the implications of rising international oil prices. In terms of pricing, China has no perfect oil futures market; it has yet to establish a pricing mechanism for imported oil based on procurement risk and, therefore, does not have the muscle to influence international oil prices. If the price of oil rises, China has to pay a premium that western countries do not. As a result of the high cost of importing crude oil, China's oil products are less competitive and its oil product companies less profitable, but household consumption expenditure keeps rising.

Fourth, China faces a complex political environment in energy diplomacy (the political risks of energy security are even greater than commercial risks). China's huge oil demand and heavy dependence on imported oil put great pressure on the international oil market. China's development of oil resources in the South China Sea and the East China Sea has led to regional conflicts over resources. China's energy diplomacy, which is directed at strategic interests and traditional geopolitics, will also impact the international order led by the USA.

In addition, China needs to address several issues related to international energy cooperation, including long-term energy cooperation strategies, establishing high-level coordination mechanisms and risk guarantee mechanisms for international cooperation, supportive financial and fiscal taxation policies, and technical support and basic research work.

\subsubsection{Challenges}

The challenges that China faces are either internal or external.

Internally, China's main challenge is insufficient international energy cooperation. First, Chinese energy companies are usually good at managing domestic projects but lack international management experience. Unlike the domestic market, international projects have a 
high level of political, economic, legal and social uncertainty. A major challenge faced by Chinese energy companies is how to integrate, optimise and use their international assets efficiently to obtain a good return, even when they lack knowledge and experience. In terms of design and profitability, Chinese energy companies have a large gap to bridge compared to their large international competitors.

Moreover, the energy acquired through direct economic cooperation is on a small scale. Direct investment in infrastructure and manufacturing is massive but insufficient in other economic fields of cooperation. Due to its lack of trading experience in international energy commodities and the absence of a fully established energy reserve system, China is incapable of effectively regulating international oil prices, and is therefore continuously exposed to fluctuations in international oil prices.

China also suffers from a lack of internationally experienced talent. The ideas, knowledge, experience and capability that come with international experience are needed to support international business operations and sharpen competitiveness. China should develop a corps of internationally experienced talent, equipped with the requisite global outlook and business capabilities to enable its energy companies to implement the Go Out strategy.

The main external challenge is conflicting approaches to cooperation. Countries differ in how they resolve conflicts and facilitate dialogue and cooperation in energy. Binding, authoritative and relevant international regimes could lower countries' transaction costs and facilitate the formation of international cooperation, according to new liberal institutionalists. As for energy security, energy shortage will promote international cooperation on energy governance, rather than lead to energy conflicts, thereby helping to eliminate such conflicts. In reality, the approach of most countries to energy cooperation combines the two ideas above or falls between one or the other. The landscape of multilateral energy cooperation is based on different answers to different problems. However, the perception that the West is drifting between the two ideas will hinder China's participation in energy governance to a large extent.

The second external challenge is the different conceptions of energy security held by different countries. Energy experts can be characterised as arguing that energy security can be ensured by markets or geostrategy. Markets convert energy from a strategic commodity into ordinary goods. Geostrategy views access to energy as a strategic issue. Experts who hold the former view consider China's dependence on imported energy will help it fit in with the global energy market system. Those who take the latter view, argue that China's efforts to reduce its dependence on energy markets will lead to conflict and threaten the stability of the international energy market. One expert pointed out that the USA classifies China's energy security strategies as part of a "strategic" paradigm and defines its own energy security policies as "market-oriented". Other experts indicated that US energy security policies are based on "hegemonic stability theory", while China's energy security strategies are based on "peaceful development theory". These different conceptions of energy security are the root cause of distrust and, as a result, poor energy cooperation between nations.

The third external challenge is the conflict of interest between participants in global energy governance, which has a negative impact. For example, long-term China-US structural conflict makes China doubt the reliability of the International Energy Agency, which is dominated by the USA. Because of differences between China and Russia on energy cooperation in Central Asia, the Shanghai Cooperation Organisation Energy Club faced a bumpy start. Historical hostility and issues between China and Japan impede energy cooperation in North-east Asia. Several countries politicise energy issues or dominate other countries' diplomacy in international dialogues on energy.

The fourth external challenge is the pressure of international competition. Although progress has been made in overseas business, Chinese energy companies are still far behind the oil majors in terms of capital operations, human resources, technology and equipment, bidding 
capability for international projects, and business experience. Large countries rich in oil and gas resources usually have a mature international energy development market. Developed economies, with strong international business capabilities and immense power, dominate the market. They enjoy a relatively monopolistic position and form strategic partnerships, which make it difficult for Chinese companies to access these markets.

The fifth is the harm caused by the China threat theory. Hidden behind energy resources are complex political relationships between countries. As international energy issues became politicised, the China energy threat theory started to spread among western countries in the early 21 st century. These countries argued that China's growing energy demand would have serious impacts on geopolitics and international energy security. Even worse, this distortion is combined with the theory that China is an economic and neo-colonialist threat in many energy-producing countries in Central Asia, West Asia, Africa and Latin America. Because western countries maliciously hype up the theory, and some countries blindly believe them, the theory seriously impacts China's overseas energy strategy and its cooperation with other countries.

The sixth challenge are the risks to China's cooperation with resource countries. These are typically political, security or legal risks, or weak infrastructure. For instance, the cooperation between China and resource countries in transnational oil and gas development faces many risks and challenges. Countries with abundant oil and gas resources in Asia, Africa and Latin America are important energy cooperation partners for China. But many of them, especially those in the Middle East and North Africa, wrestle with security issues, long-standing and more recent disputes, and sociopolitical instability. This makes international cooperation very demanding. China's economic and trade cooperation in energy with these countries is confronted by enormous risk.

The seventh external challenge is that China's energy consumption and import structures are becoming similar to those of neighbouring countries, leading to fierce competition with
Japan, India, South Korea and other countries in the international energy market. Historical disputes and political obstacles impede energy security cooperation among the East Asia countries, which makes the current regional cooperation mechanism difficult to improve.

\subsection{China's National Interest in Energy}

Energy: The 13th Five-Year Development Plan for Energy (2016-20) states that China will seize the great opportunities of the Belt and Road Initiative (BRI) to promote the interconnection of energy infrastructure across BRI countries and regions. China will implement the strategy of opening up energy markets, increase international cooperation on production capacity and actively participate in global energy governance.

Electricity: As stated in the 13th Five-Year Development Plan for the Power Industry, China will push forward the construction of cross-border power transmission and interconnected power grids, encourage businesses to take part in overseas power projects, and promote international cooperation on electric power technologies, equipment, standards, grid upgrades and engineering services.

Coal: According to the 13th Five-Year Development Plan for the Coal Industry, China will drive international coal trade and expand overseas engineering, procurement and construction projects and technical services to strengthen the international competitiveness of China's coal industry. China will also enhance coal production cooperation within the international community to promote the extraction and use of overseas coal resources. China will invest in upstream and downstream assets and build associated infrastructure to bring win-win results.

Oil: As stated in the 13th Five-Year Development Plan for the Oil Industry, China will improve international oil cooperation by exploring different ways of collaboration, increasing overseas investment and optimising the investment structure. China will also interconnect oil infrastructure in countries within the BRI. 
Natural gas: As stated in the 13th Five-Year Development Plan for Natural Gas, China will deepen cooperation with gas producers by diversifying gas supply, safeguarding cross-border pipelines to ensure supply security, enhancing cooperation with gas consumers, accelerating the formation of regional gas markets and building more pricing power in those markets.

Renewable energy: According to the 13th Five-Year Development Plan for Renewable Energy, China will actively promote global energy transition and drive the formation of a global renewable energy value chain to sharpen the international competitiveness of the renewable energy industry. China will also promote high-profile cooperation projects in the BRI countries to help consulting, contracting, equipment manufacturing and other businesses in the sector to expand their overseas markets.

\section{Box 20: Climate change risk assess- ment by the Chinese government}

A risk assessment of climate change includes: (i) future global greenhouse gas emission pathways; (ii) direct risks to the climate from global greenhouse gas emissions, and; (iii) risks caused by the interaction between climate and human beings.

\section{Future global greenhouse gas emis- sion pathways}

Current policies of the major countries and regions follow the medium to high emissions pathway, i.e. greenhouse gas emissions will continue to rise in the coming decades, then stabilise before decreasing gradually. The low emissions pathway calls for intensive technical innovation in wind power, nuclear energy, solar energy storage, biofuels, carbon storage, large-scale energy conservation and other energy technologies; otherwise, it will be hard to achieve near-zero emissions by the end of this century.
Exploitation of coal reserves, oil shale and methane hydrate will increase the likelihood of countries taking the high emissions pathway. Emissions impact the climate, so all pathways except near-zero emissions will increase risk over time.

\section{Direct risks to the climate from glo- bal greenhouse gas emissions}

The risk of climate change is nonlinear and may intensify at any time. Many factors may lead to sudden or irreversible change, causing high uncertainty.

Any emissions pathway can cause a global rise in temperature. The ability of human beings to endure heat stress is limited. Current weather conditions exceed the work safety threshold in some tropical countries. Future weather conditions could go beyond the fatal heat threshold. Crop tolerance of high temperatures is also limited. Crop yields will decrease substantially in future if weather conditions exceed the critical threshold. Therefore, climate change will bring enormous risks to global food security.

Water resource pressure intensifies with population increases. In some regions, climate change could increase the risk of acute water shortage. The probability of extreme drought on farmland will increase significantly. Although climate change mitigates water shortage in South and East Asia, it increases the risk of flooding, especially in the high emissions pathway. Frequent flooding will result in greater loss of life, crops and assets, and the need for extensive flood control at higher cost.

Climate models show that due to the inertia of the climate system, when the global temperature rises by $2^{\circ} \mathrm{C}$, global sea level will rise by $10-15$ meters with the melting of the ice cap. But when this will happen is highly uncertain. 


\section{Risks caused by the interaction between climate and human beings}

The risks of climate change are systemic. The interaction between climate and complex human systems can lead to high levels of risk. The frequent occurrence of extreme weather events has a huge impact on global food security which, combined with policies and market reaction, will result in unprecedented hikes in the global price of grain.

Climate change also increases the probability of extreme events. For example, during the 2007-11 drought in Syria, the interaction between climate change and grain export restrictions, resource pressure and poor national governance led to turmoil.

Extreme water and land shortages can lead to regional conflicts and large-scale migration, which increases the risk of state failure and can even threaten the stability of developed countries.

\subsection{China's Strategic Vision for International Energy Cooperation}

To establish a stable, effective and sustainable energy supply system, China must strengthen international energy cooperation to deliver a win-win situation. Strategically, China should deepen international energy cooperation in five areas: multi-level international energy cooperation partners, multi-channel international energy cooperation methods, diversified forms of international energy cooperation, multi-area international energy cooperation content, and multi-task international energy cooperation processes (Fig. 52).

\subsubsection{Multi-level International Energy Cooperation Partners}

Participants in international energy activities include not only energy exporters, importers and transit countries, but also international energy organisations and international energy companies. Therefore, in international energy cooperation, China needs to have multi-level partners.

In addition to strengthening cooperation with governments, China should also work with supranational, intergovernmental and international non-governmental organisations, as well as with international energy companies. Currently, Russia, the Arab states of the Persian Gulf, and countries in Latin America and North Africa are the major energy exporters. Because energy exporters are usually dominant in international energy cooperation, China needs to strengthen its cooperation with them and develop collaborative energy projects through mergers and acquisitions, equity participation and bidding. Currently, the USA, Western Europe and Japan are the major energy importers. There is potential for both competition and cooperation between China and energy importers, so it is important to strengthen communication and cooperation with large oil consumers (such as the USA, Japan, India and others) and reduce or avoid friction. Besides, China needs to enhance its cooperation with international oil exporting and consumption organisations, in particular the International Energy Agency (IEA) and the Organization of the Petroleum Exporting Countries (OPEC), and actively participate in the Energy Charter Conference, the International Energy Forum and United Nations energy conferences.

China also needs to develop international energy cooperation in crude oil with large international energy companies. It should do this by integrating oil resources and related channels in international energy markets and by establishing strategic alliances with these companies and national oil companies to gain more access to resources and projects. 
Fig. 52 China's strategic vision of future international energy cooperation

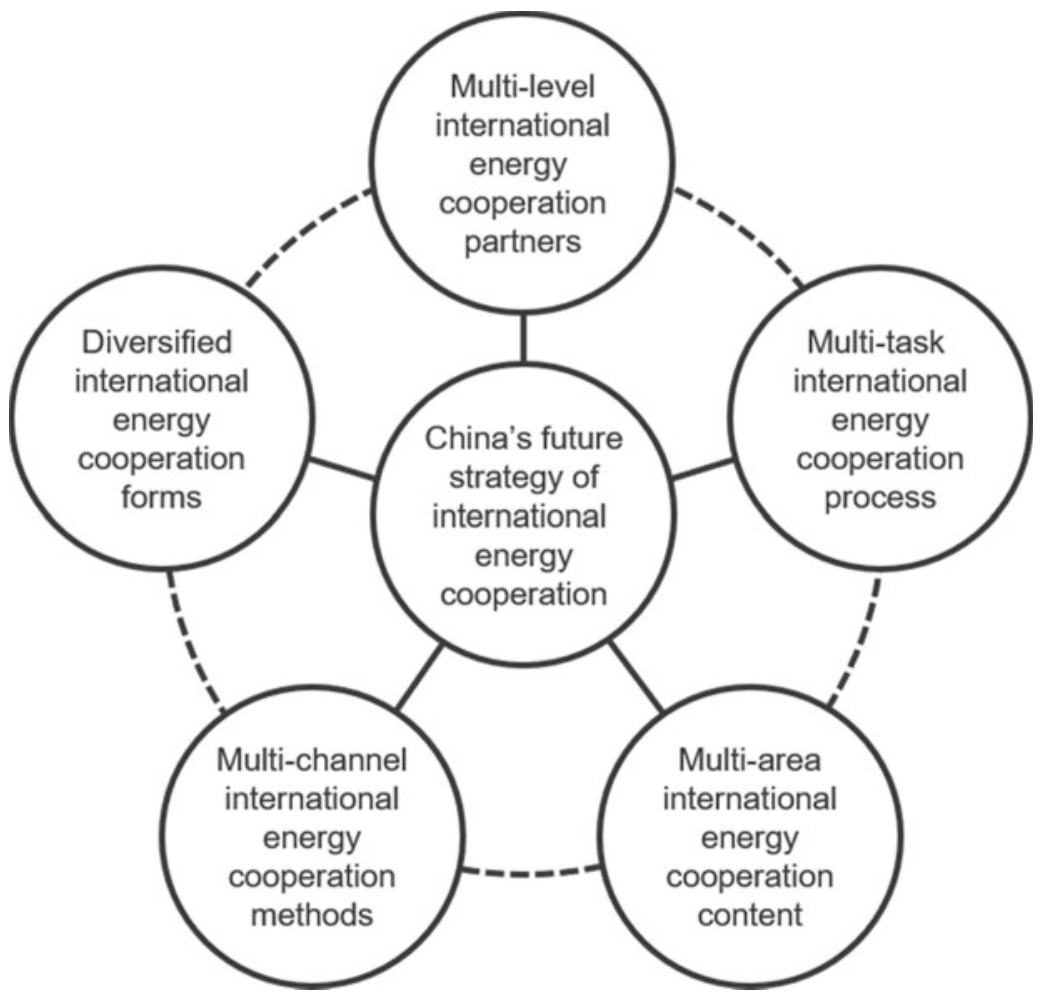

\subsubsection{Multi-channel International Energy Cooperation Methods}

China should adopt multi-channel methods in international energy cooperation, including multilateral, regional and bilateral approaches.

Multilateral energy cooperation is the most important method in international energy collaboration. To raise its influence and make its voice heard, China must participate extensively in international energy organisations, strengthen multilateral energy cooperation and security, bolster the legal and regulatory framework on multilateral energy cooperation, protect its own energy security and maximise its benefits. It is also important that China promotes extensive global dialogue with energy exporters, consumers and transit countries, and establishes and improves the international multilateral energy diplomacy mechanisms, thus achieving a balance in global energy interests and a stable energy market.

China should strengthen regional energy cooperation and promote regional integration of energy markets. Asia is an important energy supplier and a fast-growing market in energy consumption, so it plays an extremely important role in international energy supply and demand. China, as a member of Asia-Pacific Economic Cooperation (APEC), can actively promote energy cooperation in Asia. China should help form organisations for energy cooperation in East Asia, actively coordinate energy policies with East Asia countries, include oil and gas development in the Russian Far East in the East Asia energy cooperation framework to maintain energy security in the region, and support common interests. China should promote energy cooperation under the framework of the Shanghai Cooperation Organisation and work for the energy security and sustainable economic development of its members.

China should develop bilateral energy cooperation with other countries and establish good bilateral energy relationships to lay a strategic foundation for international energy cooperation. China should develop a long-term energy 
cooperation programme to strengthen efforts in energy diplomacy and improve energy cooperation mechanisms and foreign economic policies. Diversified external supply of oil and gas is a requirement of China's energy strategy, so China needs to develop bilateral energy relationships with the main oil producers in the Persian Gulf, North Africa, the Black Sea and Caspian Sea region, and the Mediterranean. China should enhance energy dialogue and participate in energy development with these regions, make them more interdependent with China, improve economic and trade ties, and secure oil delivery to the Chinese market with free trade agreements.

\subsubsection{Diversified Forms of International Energy Cooperation}

China's international energy cooperation should be implemented through different forms of international cooperation, including energy trade, agreements and investment.

In international energy trade, China should continue to actively import energy; compete extensively in the oil-rich regions; develop energy cooperation relations in Latin America, West Africa and South East Asia to diversify oil import supply; open multiple import channels that are stable, of high quality and low prices; and enhance its energy security with more international supply sources. While improving energy transport by rail, China needs to expand into new modes of energy delivery (especially pipelines), open up new seaways, enhance international cooperation to maintain maritime security, and actively explore new routes or types of transport to avoid choke points. In this way, China will diversify its delivery routes for overseas oil and maintain a leading role in maritime transport. China needs to actively participate in the international oil futures market and use its position as a big importer to curb price fluctuations and impacts, strengthen the hand of Chinese companies in external negotiations, reduce the cost of imports, strive for more control over international oil prices, and raise China's status in the international oil market.
International energy cooperation agreements involve technology and services, exploration and exploitation, environmental protection and new energy development. China should actively participate in international energy cooperation agreements to drive wide-ranging and deep collaborative relationships with other countries through mining taxation agreements, production sharing agreements, risk services, joint ventures, and so on. China should explore specific energy cooperation projects and sign agreements on oil and gas exploration with other governments. These agreements should include trade and investment, joint projects and labour export services, and upstream and downstream activities. Chinese companies can use their human and technological advantages to explore and develop oil resources in oil-producing countries and provide services in the form of engineering, procurement and construction, and earn a share of oil in proportion to their (the companies') input.

In terms of cooperation in international energy investment, China should encourage domestic companies to open overseas energy markets and increase China's share of international energy through direct investment. China should protect domestic companies in overseas energy markets by signing bilateral investment agreements with energy producers and by establishing overseas risk-taking exploration funds. China should accelerate reform of the overseas investment approval system, improve overseas investment laws and regulations, and effectively guarantee companies' rights in overseas investment and operations.

\subsubsection{Multi-area International Energy Cooperation Content}

International energy cooperation covers exploration, development, transport, processing and reserves of oil and gas, as well as environmental protection.

China can develop extensive collaborative relations with other countries in energy use, environmental protection, energy saving, management systems, laws and regulations. China's strategy of sustainable energy requires it to become more efficient in energy development 
and use, secure energy supply and protect the environment. China's dependence and impact on the international energy market opens great opportunities for its international energy and environmental industries. China's enormous demand for energy requires it to adopt comprehensive and diversified energy supply strategies, enhance international cooperation in the development and deployment of alternative energy technologies, and scale up the deployment of renewable and new energy. China needs to strengthen international energy information exchange and data sharing and increase the transparency and stability of international energy markets. It also needs to improve international energy cooperation by establishing a multilevel international dialogue mechanism covering the government, business community, academia and non-governmental organisations.

\subsubsection{Multi-task International Energy Cooperation Processes}

First, build a new international energy governance platform. Within the framework of the Belt and Road Initiative (BRI), China will establish new regional energy governance organisations, expand cooperation with existing global energy governance organisations, improve the dialogue mechanisms, promote the reform of multilateral energy laws and regulations, create energy trade rules and standards, and establish new regional energy financial systems.

Second, enable the interconnection of infrastructure networks. China will strengthen the construction of Asia-Europe infrastructure, build oil and gas pipelines in Asia, develop new combined sea and road transport routes, and construct and improve cross-border power transmission systems to create all-round, multilevel, sophisticated and interconnected energy networks.

Third, enhance international oil and gas cooperation. China will deepen industry-wide cooperation and seek the joint development of oil and gas resources, promote the diversification of overseas oil and gas resources and channels, establish world-class transnational oil and gas companies and international petroleum trading centres, and deeply involve itself in the global oil and gas pricing system.

Fourth, strengthen cooperation in clean energy and energy efficiency technologies, and lead the regional energy transition. China will increase the export of energy-efficient technologies and make more effort to strengthen cooperation in energy technology innovation and cooperation mechanisms to promote regional renewable energy development.

Fifth, drive equipment manufacturers and service companies to adopt China's Go Out policy. China will enhance international cooperation in energy equipment manufacturing, services and engineering; actively participate in equipment bidding activities for exploration and exploitation projects of shale gas, coalbed methane and offshore oil and gas in BRI countries; and encourage renewable energy equipment manufacturers of solar photovoltaic panels and wind turbines to Go Out to overseas markets. China will also encourage domestic energy think tanks to participate in the activities, research, consulting and assessment services of the International Energy Agency, and provide intellectual support to deepen international energy cooperation.

In summary, China should become an active participant in international energy cooperation and help strike a balance in international energy relations through cooperation. The Chinese government should regard the advantages of energy cooperation as an important prop to economic development and its geostrategic interests. The government should proactively carry out energy diplomacy and adopt flexible policies based on China's national interests. It should develop extensive relations with all types of international energy participants to ensure China's energy security and maintain a stable international energy market, thus facilitating sustainable economic development in China and globally. 


\section{China's Role}

and Responsibilities in Global Energy Governance

\subsection{China's Role in Global Governance Reform Is Increasingly Important}

From an outsider to an insider, from a follower to an influencer: could China promote and lead the reform of global energy governance?

\subsubsection{China Has Become a Country with the Strongest Global Economic and Energy Influence-This Influence Will Last}

(1) Economy: China has become the world's second largest economy and will remain open to maintain fast growth. Its global influence is far-reaching

Despite China undergoing structural adjustment and entering a new economic phase of slower growth, the scale, speed and quality of its economic rise remain the highest in the world. Eventually, China may overtake the USA in terms of the size of its economy, which means the relations between China and India may need to be taken into long-term consideration.

New changes are occurring in China's foreign economic relations: the first is the change in scale from being a small trading country to a large emerging economy; and the second is the structural change resulting from China's comparative advantages.

China is going to implement new strategies of openness, namely those of strengthening its emerging power, improving its international competitiveness and building mutually beneficial win-win relations with the international community. New benefits in international competition and new patterns in China's openness need effective global governance to safeguard financial security, resources and energy.
(2) Energy: China has become the world's most influential country in energy and its influence is increasing

In terms of energy supply and demand, China is the centre of the global energy industry, as it is the world's largest energy consumer. China will continue to be the largest growing energy market and is already transitioning to low-carbon energy.

(3) Trends: Forecasting global economic and energy trends is important for China, enabling it to expand its influence in international energy

The world economy is recovering, but uncertainty remains. In contrast, China's economic growth and energy development are largely ensured. The reconstruction of the global energy governance system is accelerating and the global energy landscape is adjusting. As the interests of energy producers and consumers differ, the focus of competition shifts to winning control over energy pricing, currency settlement, and transition and reform.

(4) Inclusiveness: China's participation in global energy governance is essential to improve inclusiveness and universality

The existing global energy governance system does not meet the requirements of emerging economies, including China. These countries want to take part in the governance system and address global energy supply and demand. The main defects of the current governance framework are: participants are not well represented; an effective dialogue mechanism between energy suppliers and consumers is not in place; the system does not address the diversity of energy supply, and; it does not meet multiple objectives, such as combating climate change or promoting technology transfer.

Global energy governance is evolving into a new system that is inclusive, multi-polar and 
diversified, and China's participation is essential to the universality of this system. Governance reform needs to match future requirements. The centre of energy trade is moving to the Asia-Pacific region. Climate change should be taken into consideration and electricity should be a long-term focus area.

China's participation is beneficial to the reform of global energy governance, especially to improving the system's inclusiveness and universality. Deepening the cooperation between traditional governance institutions and developing countries is in the interest of all parties. China is an indispensable partner with the largest economic volume among developing and emerging economies.

Global energy governance institutions represented by the International Energy Agency (IEA) are inviting emerging economies to participate. This benefits the emerging economies and highlights the IEA's position in global energy governance. China has also been actively involved in energy governance activities and international cooperation organisations. China's participation is essential to the universality of the future global energy governance system.

\subsubsection{China Has a Deeper Involvement in Global Energy Governance and a More Open and Flexible Attitude}

(1) Changes: China exerts more and more influence on global energy governance

China has become an active participant in, and contributor to, global energy governance. Will China become the initiator, promoter and leader of global energy governance reform?

In the future, when China markedly increases its economic strength, it will continue to open up and deepen its involvement in the international energy market. China has goals in common with other countries in energy security-its energy security is largely at one with the world's. Global energy governance plays an increasingly important role in ensuring common energy security and
China will become more and more important in global energy governance.

(2) Method: China's foreign energy relations are more open and flexible. The aim is to shift from self-sufficiency to win-win cooperation

As China moves from self-sufficiency to win-win cooperation, its foreign energy relations become more open and connected to the international energy market. China is increasingly opening up to the outside world, but it will never compromise its interests, especially in energy security. Although it is debatable whether the market can ensure energy security, China's market-oriented reform of its energy sector is an irreversible trend, especially in oil, gas and electricity.

(3) Participation: China participates more proactively in global energy governance, including global mainstream and leading regional governance organisations

China is proactively and constructively participating in global energy governance, including the International Energy Agency, G20, United Nations Framework Convention on Climate Change and others. China is also proactively leading regional and multilateral governance, exploring new governance channels and seeking win-win cooperation.

As China and the rest of the world open up to each other, China has rapidly improved its ability to participate in global governance, although gaps remain.

(4) Attitude: An open, market-oriented energy security concept is conducive to China's participation in global energy governance

Against the backdrop of energy globalisation, China needs to be prepared to work alongside and with market forces and ensure energy security within the context of an open, market-oriented energy security framework. 
China cannot step away from the international energy market and international political and economic environment. The question is: how can China compete in the global market and achieve energy security through market-oriented means.

(5) Focus: When developing strategies and plans, China needs to pay more attention to international energy cooperation and participate actively in global energy governance

According to the 13th Five-Year Development Plan for Energy (2016-20), China will assess the domestic and international energy sector to develop programmes, make full use of domestic and international markets and resources, comprehensively implement its strategy of opening up energy markets and international cooperation, seize the great opportunities brought by the Belt and Road Initiative, promote the interconnection of energy infrastructure, enhance cooperation on international production capacity, and actively participate in global energy governance. The plan defines several tasks: participating in major energy events, defining rules and regulations for international platforms and organisations, strengthening cooperation with regional organisations, and collaborating to ensure regional energy security.

\subsubsection{China Will Impact Future Global Energy Governance}

(1) Reforms: Pragmatic reform on both sides and increased cooperation are prerequisites for China's substantive participation in the mainstream governance framework

At present, China relies mainly on mainstream mechanisms in global energy governance. Substantive participation calls for reform and compromise on both sides. China's participation in the mainstream framework, led by international organisations like the IEA, requires effort from both sides. Apart from China's willingness, capacity, and strategic appeal, global energy governance needs a more inclusive framework, so reform of these international organisations has become an irreversible trend.

(2) Multilateral common ground: China is currently participating in global energy governance under the existing framework but has shown initiative by creating more flexible practices

The governance mechanisms led by China, or involving China, are concerned mainly with regional or multilateral common ground. The Belt and Road Initiative, especially with regard to the construction of energy infrastructure, will test the effectiveness of the emerging governance framework and China's influence on it.

(3) Taking the initiative: China will play an active role in the global energy governance system, but improvements to the system are necessary

China's willingness and capability are the main factors that influence China's involvement in the global energy governance system, both of which depend on China's attitude and strategic choices. China's participation in global energy governance requires it to create the right conditions for its involvement. In terms of its own interests, the costs, benefits and risks are the key to China's further involvement in the global energy governance system. With respect to its approach, should China work to improve the existing mechanisms or make a radical restart?

(4) Implications: China's participation in global energy governance will have deep and extensive impacts

China's participation in global energy governance will affect the existing governance framework and its participants in profound and different ways. First, how will China's participation or actions affect the objectives and operation of the existing governance system? Second, how will China's participation affect the interests of other participants in the existing system? As 
can be seen above, win-win governance thanks to China's participation will become possible.

\section{Box 21: The concept of global energy governance}

Governance is an important part of global energy cooperation. It consists of international narratives, norms, rules and formal and informal organisations that have direct or indirect impact on energy production, trade and consumption.

1. Global energy governance is a series of arrangements centred on the governments of sovereign countries. It includes multilateral conventions, international and regional organisations and bilateral partnerships.

2. It also includes the arrangements by which important roles are played by non-state organisations, such as global or regional energy exchanges, arbitration mechanisms, supply chain initiatives, and so on. Energy governance organisations usually involve alliances with different stakeholders, including governments, companies, international organisations, cities, and non-governmental organisations. These stakeholders all participate in an orderly, predictable international framework that is related to energy production, trade and consumption.

\section{Box 22: The advantages and disad- vantages of conventional governance systems}

1. International Energy Agency (IEA): An experienced, professional organisation with strong executive power, but lacking inclusiveness and the ability to develop. How distant is China to it? What is China's relation to it? How many conditions (such as OECD membership) are there and what will be the cost of reform?

2. Group 20 (G20): A highly authoritative and representative organisation covering most of the major energy suppliers and consumers but lacking a dedicated secretariat and executive power. Will the G20 Energy Sustainability Working Group become a platform for leaders of large countries to demonstrate their energy and political power?

3. Belt and Road initiative (BRI): An initiative promoted and led by China and covering most economies, except those in North and South America. It has difficulty balancing supply and demand and in providing services other than the construction of energy infrastructure. The impact of BRI on the mainstream energy governance framework, and its relationship with the IEA and the G20, are not clear.

\section{Box 23: China's participation in global energy governance}

China's participation in global energy governance, which has been continuously expanded and deepened, is closely related to the global political, economic and energy landscape.

China was an outsider in all international energy mechanisms before it opened its economy, after which it gradually integrated with the world and began to participate in global energy governance. In 1983, China became a member of the World Energy Council. During this initial period, China was cautious and focused on exploring and studying international rules. Since the 1990s, with the development of its economy, China began to actively participate in global energy governance. In 1991, China joined the APEC Energy Working Group. It then participated in 
regional energy cooperation mechanisms. However, China's involvement was not deep at that time, so the symbolism of its participation outweighed the effects. Entering the 21st century, and with increasing globalisation, China started to make more effective contributions to global energy issues. Its role shifted from active participant to active influencer. It has developed cooperation in various forms with the International Energy Agency (IEA), the International Energy Forum, the Organization of Petroleum Exporting Countries (OPEC), the Energy Charter, the International Renewable Energy Agency and the International Atomic Energy Agency as a member, ally, dialogue partner or observer, and played an important role in several major energy issues. In particular, China became the promoter of some major energy issues through the G20, BRICS countries (Brazil, Russia, India, China, and South Africa), Asia-Pacific Economic Cooperation (APEC) and Shanghai Cooperation Organisation.

China is also a founding member of many international energy organisations, such as the International Energy Forum, Joint Organisations Data Initiative, International Partnership for Energy Efficiency Cooperation, and the Clean Energy Ministerial. China has also actively participated in and hosted many international energy conferences. In November 2015, China became one of first IEA associate members. In 2016, China hosted the G20 Summit in Hangzhou, where global energy governance was an important topic.

Source IEA, China's Engagement in Global Energy Governance (2016)
Box 24: The relationship between the Belt and Road Initiative and international cooperation on energy and global energy governance

Energy cooperation is an important part of the Belt and Road initiative (BRI). Strategically, it is necessary to clarify the position of energy cooperation and its scope and role, as well as the impacts of energy cooperation on BRI and global energy governance.

1. BRI can bring dividends to regional energy cooperation. First, energy cooperation can lead, influence and drive other actions during the implementation of BRI. Second, energy cooperation is the foundation for building a community of common political, economic and energy security.

2. Energy cooperation in BRI requires certain conditions to thrive. These include defining mutual benefits, win-win cooperation and incremental progress, a common understanding of cooperation and open economies, prioritising the role of the market and making companies the main actors, implementing a strategy of effective checks and balances, and bilateral cooperation within a multilateral environment.

3. Key energy collaboration areas in BRI are strengthening cooperation in the construction of energy infrastructure to improve regional energy trade and energy security; interconnecting oil, gas and electricity facilities; cooperating in energy production, processing and use to guarantee regional energy security; establishing regional energy 
cooperation platforms and mechanisms to enhance energy cooperation and security.

4. There are differences between energy cooperation within BRI and mainstream global energy governance mechanisms. First, BRI has new requirements for global energy governance, such as: a top-level inclusive platform for negotiating win-win energy cooperation, a relevant and professional platform for promoting the interconnection of energy infrastructure, and a platform for flexible competition and coordination that ensures long-term investment in energy. Second, energy cooperation in BRI makes the inadequacies of global energy governance more obvious, such as the low level of inclusiveness, lack of multilateral negotiation mechanisms to promote the interconnection of energy, lack of rules and regulations facilitating regional energy trade and investment, lack of financial mechanisms to ensure long-term energy investment, and lack of a dialogue mechanism that covers political, economic and energy security.

5. The international community is cautious about the goals and energy cooperation proposed by BRI, especially with regard to benefits that can be achieved in energy supply and energy demand. Some countries are concerned about the goals of BRI, its ability to implement projects sustainably and the risk of using a market-oriented model.

\section{Box 25: China should have a long-term plan for global energy governance}

1. China needs to clearly recognise how future trends in global energy governance will positively or negatively influence China and other emerging economies, as this will affect China's willingness to participate in international governance and its strategies of participation. This is related to the compromises that can be made with other participants and the conditions, costs, benefits and risks of China's participation.

2. China should also recognise its unique status as a large developing economy that has an increasing need for energy, while undergoing an energy transition. China needs to understand correctly how it differs from the core interests of other participants (mainly developed countries) in the global energy governance framework. And, China needs to appreciate the complexity of, and potential changes in, its relations with other participants, as these are closely tied to economic development and the pressures of controlling climate change.

3. China must clearly recognise that energy security is the main goal of its participation in global energy governance and the driver of its external energy relations. It is impossible to convince China in the short term that external markets alone can ensure 
energy security; domestic market reform is also required to create the necessary conditions for energy security. China's energy security continues to be goal-oriented, i.e. the continuous, sufficient and economical supply of energy is the primary goal; efficiency and fairness are secondary. China's energy security cannot be achieved simply by joining the mainstream governance system or international energy organisations.

\subsection{China's Responsibilities in Global Energy Governance}

\subsubsection{China Should Shoulder the Responsibilities of a Major Power in Global Energy Governance}

(1) In terms of global energy governance, if China takes the responsibilities of a major power, China and the world will benefit

China should actively participate in and improve global energy governance by ensuring energy security is the key factor and by dealing with the connection between climate governance and trade governance.

(2) With regard to climate change, China has signed the Paris Agreement and will assume its emission reduction responsibilities in a fair way

China will assume its emission reduction responsibilities at its own pace. The energy transition is an internal driver for China, more so than an external one.
(3) The transformation of the domestic energy system is already in progress, driven by the goals of China's energy revolution

China's transition to a clean, low-carbon energy system is under way. This benefits both China and the world. The import and use of natural gas and other low-carbon energy is part of this energy transition.

(4) China will continue to open up and insist on proactive and win-win cooperation with others in international energy

China will actively participate in mainstream global energy governance and cooperate regionally with neighbouring countries. Promoting energy infrastructure construction under the Belt and Road Initiative helps developing countries escape from energy poverty quickly and enables China to develop its energy equipment industry.

At the strategic level, China has proposed goals and responsibilities for its participation in global energy governance and international energy cooperation. The strategy clearly requires China to actively participate in global energy governance and shoulder its international responsibilities and obligations. China will seek to reform global energy governance, consolidate and improve its bilateral and multilateral energy cooperation mechanisms, and actively participate in international institutional reform.

\subsubsection{Regional and Multilateral Cooperation Will Coordinate Energy Security with Socioeconomic Development}

(1) Multilateral international cooperation is important, both for China and globalisation 
As the global energy market is now highly integrated, "in an interdependent situation, rational and self-interest-driven actors will take the international mechanism as a way to increase their ability to reach a mutually beneficial agreement".

(2) China has the responsibility to form a community of common interests and promote common energy security through regional and multilateral cooperation

China has the responsibility to develop deep cooperation with global and regional organisations and establish stable cooperative relations with others in energy supply and demand. As China participates in regional multilateral governance, it has the responsibility to promote common regional energy security and the joint development of all parties' energy economies.

(3) In the future, China will have the responsibility to assume different governance roles at regional and multilateral levels

Experience shows that China can promote and lead multilateral energy governance. China's role varies in different governance frameworks. In the future, China will have the responsibility to shoulder different governance roles.

(4) China has the responsibility to promote equal and mutually beneficial bilateral and multilateral cooperation

Bilateral, multilateral and global energy cooperation can be described as: "bilateral cooperation lays the foundation, multilateral cooperation improves quality, and global governance seeks common ground". Bilateral cooperation has fewer requirements and is easier to achieve. It serves as the foundation for more extensive and deeper international energy cooperation and global energy governance. At present, China has the responsibility to manage its relationship with those countries with which it has close energy cooperation.
In the medium and long terms, China will have the responsibility to evolve bilateral forms of energy cooperation into a more extensive and deeper multilateral cooperation.

\subsubsection{China's Responsibilities Are to Improve Its Energy Security and Make Global Energy Security More Inclusive and Collaborative}

(1) China's energy security is critical to global energy security

China ensures its energy security by participating in global energy governance. This is beneficial to energy suppliers and to countries dependent on energy imports. Global energy governance with multilateral participation, including China's, is more inclusive and more likely to achieve common energy security.

(2) Better international energy cooperation and global energy governance would strengthen China's energy security, energy transition and long-term development

The Chinese government has a new security strategy based on mutual trust, mutual benefits, equality and coordination. The government emphasises the need to address differences, enhance mutual trust through dialogue, resolve disputes through negotiation, and strengthen security through cooperation. Globally, China should take as its starting point the need to improve the basic rules of the international system, actively advocate or lead the improvement of international mechanisms or establish new ones, improve its ability to set agendas and become a major policymaker in international regulations, and become an active contributor to global energy governance - one perceived as responsible and predictable. 


\subsection{Predicting the Future of Global Energy Governance}

Global energy governance reform is about inclusiveness and looking forward to the future. Does an ideal form of governance exist or not?

\subsubsection{In the Short and Medium Terms, It Will Become Increasingly Urgent to Reform Mainstream Governance Organisations}

(1) New mechanisms and new institutions are needed, but it will take time

There is a need to create new mechanisms and institutions to accomplish new missions in global energy governance. New mechanisms and new institutions will be more beneficial to the future of global energy governance, but this cannot be accomplished at one stroke. New mechanisms and new institutions can solve many problems that existing mechanisms and institutions cannot solve, but it is not an easy task to create them.

\section{(2) Reform should be pragmatic}

There is a consensus that global energy governance requires new mechanisms and new institutions, but this does not mean that new institutions need to be formed within a short time. Establishing new institutions costs time and money and may be impeded by political factors. It may therefore be more realistic to reform the existing mechanisms and institutions. To do so, it is necessary to be fully aware of the difficulties of reform and devise pragmatic plans.

A mainstream governance institution like the International Energy Agency should deepen its reform of inclusiveness, reformulate strategic objectives and transform itself into a global energy institution. More emerging economies should be admitted, and the economic transition of OPEC countries facilitated. The financial derivatives market and global energy pricing should be examined for reform and a more universal alternative explored. Consensus and trust should be built to avoid differences of interest after expansion and inclusion.

\subsubsection{In the Long Term, Global Energy Governance Will Extend Beyond Energy Supply and Demand}

(1) Future global energy governance should ensure global energy security

A more inclusive and balanced global energy governance system should look to the future and strengthen global energy security.

(2) New missions and tasks in global energy governance will be more diverse, inclusive and balanced

New missions and tasks to achieve a more inclusive and balanced global energy governance system should: improve the governance framework and strengthen international cooperation and policy alignment; mitigate climate change and regional pollution; cover financial investment, bulk commodity trading, information and data sharing; and improve technical progress and technology transfer in energy.

This can be achieved in the following ways: (i) consolidate the common security concept of global energy; (ii) address environmental challenges like climate change and local pollution; (iii) strengthen multilateral international cooperation mechanisms and share best practice in energy development and use; (iv) use existing energy governance mechanisms; (v) build jointly new international cooperation frameworks, including those for energy and finance; (vi) extend the existing financial analysis of commodity markets into the energy sector; (vii) establish a dialogue on policies that improve stability in key energy-producing regions; (viii) improve energy market transparency and the quality of data; (ix) establish effective strategic reserve mechanisms and cooperation methods; (x) improve 
fairness in energy trading and energy investment; and (xi) improve jointly energy efficiency, energy innovation and new energy technologies.

\subsubsection{Will the Ideal Energy Governance Framework Be G20 + IEA + .....? And Will It Be Truly Global?}

(1) All organisations, governance and frameworks have the potential to lead global energy

The G20 focuses on general issues, while the IEA concentrates on specific ones. The two organisations do not operate at the same level, nor do they have substantive competition or cooperation. However, both have the potential for global energy governance and display different types of leadership in global social development and energy security.

First, both organisations comprise member countries that are independent economies (except for the EU). They are comprehensive, inclusive and responsive to the needs of emerging and developing countries. They have the ability to build more mature and stable relations between energy producers (including OPEC countries) and consumers.

Second, they complement each other in terms of professionalism, influence and executive power, but both need to compromise. The G20 should significantly improve its Energy Working Group, while the IEA needs to reform to become a global institution. At the same time, the two organisations should form a closer working relationship by, for example, enhancing international laws and regulations for investment protection, and by supporting emerging economies and countries to develop their own low-carbon strategy.

Third, it is essential that they coordinate the relationship between oil and gas exporting and importing countries and balance the interests of countries like Saudi Arabia and Russia that rely heavily on oil and gas exports.
Fourth, the path of combining two organisations into one and the position of the successor organisation is uncertain, so questions like expanding the number of members still need to be considered. In addition, it is important to manage the relationship with other international institutions, such as the United Nations Framework Convention on Climate Change (UNFCCC), the Organization of the Petroleum Exporting Countries (OPEC), the International Energy Forum, the Clean Energy Ministerial, the International Renewable Energy Agency, the International Partnership for Energy Efficiency Cooperation, the Energy Charter Treaty, and others in the energy sector. Institutions outside energy that have a much broader coverage include the Organisation for Economic Co-operation and Development (OECD), the World Trade Organization (WTO) and the World Bank.

(2) The successor governance organisation will still need all parties to eliminate differences of interest, political risk and other uncertainties

The biggest advantage of the successor governance organisation is that it will be inclusive and representative, which plugs the gap in international cooperation and international market supervision. The disadvantage is that it requires long-term and unremitting efforts from multiple parties.

China's Energy Research Institute believes that the G7 and the BRICS countries (Brazil, Russia, India, China and South Africa) can build a new energy governance organisation based on equal participation. This mechanism could provide guidance for existing energy governance institutions like the IEA, the World Bank and the WTO, and broaden cooperation with them.

Another option is the G7 + BRIC (Brazil, Russia, India, and China) + six international organisations (IEA, OPEC, UNFCCC, WTO, the International Monetary Fund and the World Bank).

The G7 (or G20) + BRICS + IEA + another option has a broad base of participants that cover 
much of the world economy and global energy. In terms of energy consumption, it covers the main developed countries and emerging economies; and in terms of energy security, it covers issues like strategic oil reserves and crisis management, producer and consumer organisations, climate change, energy markets, price and financial regulations, and energy poverty and energy equality. However, as there are many participants and their interests vary greatly, the political risks of different parties failing to compromise needs to be considered.

\subsubsection{Plan Ahead, Face the Challenges and Find Solutions in Global Energy Governance}

(1) The connection between climate governance and energy governance will become increasingly prominent in the next two decades

As we approach 2030, the link between energy security and carbon reduction will intensify. The question of energy security could be replaced by climate change, which could seriously alter the status of global energy governance.

First, energy security will not be replaced by climate change in the short term. Fossil fuels will remain the world's main energy carriers for the next 20 years at least, though the possibility cannot be ruled out that local trade flows of oil and gas will change.

Second, emerging economies are undergoing both an economic and an energy transition. Increased electrification and the lower cost of decarbonised energy will accelerate the substitution of power for conventional fossil fuels. This will change the focus from energy security to power security and adjust the action plan to ensure energy security converges with combating climate change.

Third, for now, global energy governance is related to global trade governance. Differences in carbon taxation are likely to imperil the current WTO free trade principles and may also affect bilateral trade interests. Different countries develop differently, so the carbon tax and its impacts should be evaluated accordingly. It should be noted that the convergence of energy security with combating climate change is a long process.

(2) Energy governance will impact the energy security of developing countries

The need for policies and actions in the energy sector to address climate change are becoming incontestable. As a result, the prevailing global energy governance values are in transition. This could threaten the energy security of emerging economies, including China's. Developed countries are happy to see emerging economies pledge huge nationally determined contributions but neglect the cost. If carbon cost is added to oil and gas products in global trade too early, the cost to oil and gas importing countries will increase. This will impact their energy security and may be detrimental to exporters as well.

\subsection{Policy Proposals}

All participants should actively contribute to the reform of global energy governance.

\subsubsection{For the Chinese Government, This Means Strategy Formulation, Internal Development, Active Participation and Achieving Breakthroughs at Home}

(1) Develop strategies for cooperation with, and the reform of, international energy governance organisations

It is in China's interests to firmly adhere to multilateral norms and international rules, seize opportunities and address challenges together with the international community, and actively and inclusively participate in global energy governance. This requires China to research and develop national strategies for participation in 
international energy cooperation and global energy governance.

This study proposes that China should: (i), draw up strategies and a roadmap for its participation in global energy governance and evaluate the cost and benefits of participating in global energy governance in different scenarios. This would include identifying the various methods of engagement and providing the necessary support systems; (ii), actively respond to the expectations of the international community for China's participation in global energy governance, such as the IEA's oil emergency response mechanism and the improvement of data quality; (iii), establish an internal conference and consultation mechanism to reach agreement on major international issues, using authorised delegates, to make China's voice heard at international conferences; (iv), prepare a list of international energy conferences and activities to attend and identify the department and officials who should participate and the goals they should achieve; (v), release transparent national energy policies on a regular basis, including white papers on China's domestic energy policies and external energy relations, and; (vi), set up an emergency system (like strategic oil reserves) for potential energy security problems (like armed conflict).

\section{(2) Develop domestic capabilities to strengthen China's engagement in global energy governance}

Boosting China's capabilities to modernise energy governance is a prerequisite for its participation in global energy governance.

First, China should develop the capability to set international energy agenda, especially those representing emerging economies and developing countries (soft power).

Second, China should develop the capability to expertly apply international energy regulations, especially those on international energy trade and financial investment.

Third, China should optimise domestic energy governance and develop a modern governmental structure for energy diplomacy, focusing on reforming the domestic energy governance system and international energy cooperation mechanism.

Fourth, China should improve the development of human resources for international energy governance.

Fifth, China should improve the capability of energy companies to participate in international energy market activities and fully serve the international energy market.

Sixth, China should build discussion platforms with the help of unofficial and international organisations and enhance research and capacity building for participation in global energy governance.

\section{(3) Opening up to one another and fostering faith in the international energy market can support energy security}

Future global energy governance will be dependent on China and the world opening up to each other. China should be aware that the international energy market, when it functions well, can ensure energy security through strong and liquid trading to match supply with demand.

There is global consensus that the international energy market ensures energy security under normal economic and geopolitical circumstances. Dependence on imported energy (mainly oil and gas) is no longer a measure of energy security. In the future, energy shortage may not be as critical as before and energy commodities procured from the international market may be cheaper than those produced in China-this is thanks to globalisation, countries opening up to each other, the energy transition and China's energy revolution.

Second, opening up China's energy resources in certain fields not only involves energy development but also investment and trade. Win-win energy development can be achieved by defining areas for international cooperation, learning from international energy development experience and advanced technologies, and using foreign investment to make domestic energy markets more competitive. China's further integration into the global energy market will contribute to the energy security of the whole world. 
(4) Making breakthroughs, integrating different governance organisations and sharing China's successes

The costs, benefits and risks of China participating in energy governance mechanisms differ from one mechanism to another. China is more likely to make a breakthrough in a governance organisation in which it has a leadership role (such as energy cooperation in the Belt and Road Initiative). Even if the aims and jurisdictions of international energy cooperation and global energy governance differ, the benefits of cooperation and China's successful experience help to improve global energy governance.

In 2016, China made breakthroughs in its energy cooperation with the G20 and the IEA. China became an associate member of the IEA, the current global energy governance organisation, indicating China's progress in mainstream global energy governance. The G20 is a global economic governance mechanism, of which China is a founding member. The G20 provides an arena for China to enhance its leadership in global energy governance.

Promoting energy cooperation in the Belt and Road Initiative and reforming global energy governance are equally important to China and mainstream global energy governance organisations like the IEA. This study proposes that China:

(i) enhance transparency of all policies and strengthen mutual trust to create a win-win situation and an energy cooperation mechanism that works under normal economic and geopolitical circumstances;

(ii) actively reform global energy governance. Reform includes comprehensive cooperation with existing mainstream international organisations and the promotion of China's policies and proposals, active participation in the formulation and reform of multilateral laws and rules of energy governance, and advancing the view that all parties share equally the benefits and risks of energy governance and compete in an orderly way; and

(iii) actively innovate governance platforms and promote dialogue between them, such as that between the Belt and Road Initiative and global organisations like the IEA, OPEC, SCO, EU, OECD and WTO.

\subsubsection{The International Community Should Make the Mainstream Governance System More Inclusive}

(1) The existing global energy governance framework does not meet the needs of a globalised world, so reform to make it more inclusive is urgent

The current governance mechanism is unable to solve risks effectively - political, legal, and the risk of corruption during energy investment. Some energy governance mechanisms are regionally focused and have not been applied globally; others are becoming less effective with time.

Despite twists and turns, globalisation is irreversible. So, global governance is essential and global energy governance is an important part of global economic governance. Policies that integrate energy suppliers with consumers are becoming increasingly tighter. In particular, as the USA becomes energy independent and the oil and gas consumption of developed countries peaks (developed countries are unlikely to increase consumption), only China and India will have the potential to increase oil and gas consumption. Emerging and developing economies are, therefore, the cooperation partners that the IEA and OPEC strive for.

Thanks to globalisation, energy security is not as critical as before. Only by improving inclusiveness can the challenges of global energy 
governance be addressed. Inclusiveness means not only that the IEA framework should cover more oil and gas consumers, but also that a higher-level framework should be in place to manage relations between the IEA and OPEC and form a new community of energy interests.

(2) The G20 and IEA are the main global governance institutions - their integration requires political compromise

At present, the global energy governance framework is divided into three levels. The first level is the United Nations and G20. They are not energy governance organisations, but they can deliver strategic policy orientations that have a broad consensus and influence energy governance. The second level is represented by professional energy governance organisations like the IEA. They are energy clubs whose members are developed economies. Non-OECD members that are not part of OPEC are often partners of the IEA. OPEC, as a producer organisation, is the IEA's counterpart, but its executive power is now declining. Organisations at this level tend to be well run, strongly executive and professional. The third level is represented by emerging professional energy governance organisations like the International Renewable Energy Agency (IRENA), the International Energy Forum (IEF) and the Energy Charter. They exert vertical governance in most cases and often cooperate with the G20 and other organisations at higher levels.

Integrating the first and second levels (the G20 with the IEA and OECD) requires political compromise, which means it will be a long-term process. The willingness of OECD countries to compromise in the non-energy field will affect the IEA. Mainstream energy governance organisations like the IEA need to reform and become more inclusive. Integrating the interests of the IEA and OPEC is harder than integrating the interests of energy-consuming countries like China and India. It can only be achieved through global governance at the first level, which is a long-term process.

Integrating global energy governance with social and economic development is important. The inclusive Belt and Road Initiative framework complements the professionalism of IEA energy governance. They could learn from one another. Integrating global energy governance into social and economic development helps broaden consensus on global energy governance.

\section{(3) High-level G20-IEA energy governance would help coordinate climate control and lower-level energy governance}

Global energy governance within the G20-IEA framework would be at a higher level and more inclusive than the current IEA and would be more professional and executive in terms of energy governance than the current G20. Global energy governance under the integrated G20 and IEA would be similar to global climate control in terms of level, effectiveness and inclusiveness.

In the short term, the fate of climate control lies in the energy transition and energy governance, so the G20-IEA framework would help create a win-win situation. The benefits for oil and gas importers are obvious, as it subjects OPEC oil and gas exporters to a system of checks and balances and encourages them to transition to cleaner energy.

In the long term, consensus on climate control helps suppliers and consumers reach agreement on energy. This agreement goes beyond any of the previous energy security approaches (sufficient, sustainable and affordable) centred on oil and gas security in the narrow sense. Instead, it focuses on the sustainability of energy security (green, effective, fair, etc.) and helps push supply and demand towards clean, low-carbon energy. 


\subsubsection{Stakeholders Are Looking to the Future and Planning for Global Collaborative Energy Security}

(1) International non-energy organisations should keep pace with global energy governance reform

Organisations like the WTO should consider introducing energy trade rules to address the changing modes of global trade. Current WTO trade rules need to be reformed to meet the need for inclusiveness, digital intelligence, efficiency and convenience in the context of globalisation. In energy, these requirements are: first, there may be changes in the flow and types of oil trade, and a globally unified liquefied natural gas (LNG) market could come into existence; second, despite the strict controls of oil and gas producers, the trade rules in upstream oil and gas and other services are global and homogeneous; third, the vision of transnational or transcontinental power trading can be realised.

The World Bank, International Monetary Fund and other organisations should plan early for investment in the low-carbon age. In the future, especially after 2030, global oil and gas consumption could peak or stay at a high level, with growth no longer possible. In a low-carbon power system, electricity generated with fossil energy will decline. It is likely that the financial return from investments in fossil energy, especially power, will be lower than previously. It will be important that these organisations adapt and invest in sustainable energy in the low-carbon age.
(2) The future global energy governance framework and the Belt and Road Initiative should provide oil and gas exporting countries with the opportunity to transition

Supplies of oil and gas are expected to increase in the future. China and India are located in the geographical mid-point between Russia, Saudi Arabia and other OPEC countries and the USA. Russia and Saudi Arabia should speed up their transition to reduce their over-dependence on oil and gas exports. The Belt and Road Initiative provides them with opportunities for social development and economic transition, including the transition of energy. China is strengthening its cooperation with the Gulf states to interconnect energy infrastructure. Multilateral consensus is expected to be formed and converted into investment. The future global energy governance framework and leading organisations should also make efforts to broaden consensus beyond energy.

(3) Only with the comprehensive and collaborative transition of energy consumers and energy exporters can common global energy security be achieved

The world is a whole, so the interests of energy producers, consumers and exporters should be taken into consideration to achieve balance. This requires long-term concerted effort by international organisations and the countries concerned. Global energy governance will become more significant in this long-term process, so it needs to reform itself continuously to keep pace with the times. 


\section{Appendix}

\section{Annex A.1: Inventory of Multilateral Global Governance Mechanisms, Institutions and Forums}

\begin{tabular}{|c|c|c|c|c|c|c|}
\hline Mechanism/process/organisation & Relevant function & Trade & Investment & Innovatior & $\begin{array}{l}\text { Security } \\
\text { of } \\
\text { supply }\end{array}$ & Externals \\
\hline
\end{tabular}

Major institutions with energy/climate gov. remit

World Trade Organization (WTO)

G20

OECD

Multilateral development banks e.g. World Bank, AIIB

United Nations Development Programme (UNDP)

Bilateral investment treaties (BIT)

Shanghai Cooperation

Organisation (SCO)

Arctic Council

UN Convention on the Law of the Sea (UNCLOS)
Trade rules incl.

Environmental

Goods Agreement, and dispute resolution

Energy principles and activities on subsidies removal, climate risk disclosure, and energy for all

Information and policy guidance, trade and investment conventions

Policy and tech. assistance; investment guarantees (MIGA), dispute resolution (ICSID) and investment standards (IFC); gas flaring

Climate adaptation, energy access, resilience

Trade rules, recourse to arbitration

Economic, security and resource cooperation

Intergovernmental forum (Arctic environment, navigation)

International navigation, boundary disputes, marine environment 


\begin{tabular}{|c|c|c|c|c|c|c|}
\hline Mechanism/process/organisation & Relevant function & Trade & Investment & Innovation & $\begin{array}{l}\text { Security } \\
\text { of } \\
\text { supply }\end{array}$ & Externals \\
\hline BRICs & $\begin{array}{l}\text { Cooperation on } \\
\text { energy security and } \\
\text { efficiency }\end{array}$ & & & & & \\
\hline \multicolumn{7}{|c|}{ Major energy and climate organisations } \\
\hline UNFCCC & $\begin{array}{l}\text { Emissions reduction } \\
\text { under INDCs, } \\
\text { investment }\end{array}$ & & & & & \\
\hline $\begin{array}{l}\text { UN Sustainable Development } \\
\text { Goals (SDGs) }\end{array}$ & Access to Energy & & & & & \\
\hline $\begin{array}{l}\text { International Energy Agency } \\
\text { (IEA) }\end{array}$ & $\begin{array}{l}\text { Emergency Response } \\
\text { Mechanism, } \\
\text { technology roadmaps }\end{array}$ & & & & & \\
\hline $\begin{array}{l}\text { Org. of the Petroleum Exporting } \\
\text { Countries (OPEC) }\end{array}$ & Production quotas & & & & & \\
\hline $\begin{array}{l}\text { International Energy Forum } \\
\text { (IEF) }\end{array}$ & $\begin{array}{l}\text { Ministerial dialogue, } \\
\text { data (Joint } \\
\text { Organisations } \\
\text { Database Initiative) }\end{array}$ & & & & & \\
\hline $\begin{array}{l}\text { International Renewable Energy } \\
\text { Agency (IRENA) }\end{array}$ & $\begin{array}{l}\text { Policy and technical } \\
\text { assistance, } \\
\text { technology }\end{array}$ & & & & & \\
\hline Energy Charter Treaty & $\begin{array}{l}\text { Trade rules, fuel in } \\
\text { transit, dispute } \\
\text { resolution, energy } \\
\text { efficiency }\end{array}$ & & & & & \\
\hline $\begin{array}{l}\text { Extractive Industries } \\
\text { Transparency Initiative (EITI) }\end{array}$ & $\begin{array}{l}\text { Transparency of } \\
\text { revenues }\end{array}$ & & & & & \\
\hline \multicolumn{7}{|c|}{ Other significant agencies/processes } \\
\hline $\begin{array}{l}\text { Global Green Growth Initiative } \\
\text { (GGGI) }\end{array}$ & $\begin{array}{l}\text { Policy and technical } \\
\text { assistance }\end{array}$ & & & & & \\
\hline Mission Innovation & Finance energy R\&D & & & & & \\
\hline Clean Energy Ministerial & $\begin{array}{l}\text { Scaling up clean } \\
\text { energy }\end{array}$ & & & & & \\
\hline $\begin{array}{l}\text { International Emissions Trading } \\
\text { Association (IETA) }\end{array}$ & $\begin{array}{l}\text { International } \\
\text { framework for } \\
\text { trading in greenhouse } \\
\text { gas reductions }\end{array}$ & & & & & \\
\hline Cities 40 (C40) & $\begin{array}{l}\text { Transport, green } \\
\text { buildings }\end{array}$ & & & & & \\
\hline $\begin{array}{l}\text { Climate and Clean Air Coalition } \\
\text { (CCAC) }\end{array}$ & Improving air quality & & & & & \\
\hline Climate Invest Funds (CIF) & $\begin{array}{l}\text { Scaling up climate, } \\
\text { clean energy } \\
\text { investment }\end{array}$ & & & & & \\
\hline
\end{tabular}




\begin{tabular}{|c|c|c|c|c|c|c|}
\hline Mechanism/process/organisation & Relevant function & Trade & Investment & Innovation & $\begin{array}{l}\text { Security } \\
\text { of } \\
\text { supply }\end{array}$ & Externals \\
\hline
\end{tabular}

\section{Other}

Kimberley Process, Better Gold, Supply chain

Dodd-Frank transparency

Equator Principles

Investment standards

ISO (oil), Euro (Auto),

Product standards

ASEAN and ASEAN Plus Three

Petroleum Security

Agreement

Comb. Maritime Taskforces

Security of sea lanes

International Maritime

Organization (IMO)

Fuel efficiency, fuel

standards,

environment

\section{Annex A.2: Relevant Actors and International Experience}

See Tables 2, 3, 4, 5, 6.

Table 2 Relevant actors and international experience in the strategic pathway of reforming the IEA to make it more representative, effective and relevant

\begin{tabular}{|c|c|c|}
\hline & Regional oil and gas security & IEA reform process \\
\hline $\begin{array}{l}\text { International } \\
\text { experience }\end{array}$ & $\begin{array}{l}\text { Energy Charter Treaty, G20 Energy } \\
\text { Ministerial Communiqué 2016, G20 } \\
\text { Principles on Energy Collaboration }\end{array}$ & $\begin{array}{l}\text { IMF precedent, Norway precedent, Russian } \\
\text { membership of Nuclear Energy Agency }\end{array}$ \\
\hline State actors & $\begin{array}{l}\text { National Energy Administration (NEA) of } \\
\text { China, Ministry of Economy, Trade and } \\
\text { Industry (METI) of Japan, and Korea Energy } \\
\text { Economics Institute (KEEI), Indonesia, Laos, } \\
\text { Malaysia, Myanmar, Philippines, Thailand } \\
\text { and Vietnam }\end{array}$ & $\begin{array}{l}\text { China, India and Indonesia (existing G20 } \\
\text { association members) plus (e.g. Russia, } \\
\text { Brazil, South Africa-partner countries) to } \\
\text { make proposal for IEA reform at G20 }\end{array}$ \\
\hline Non-state actors & ASEAN Centre for Energy & \\
\hline $\begin{array}{l}\text { Governmental } \\
\text { expert group } \\
(\mathrm{GEG}) / \text { multilaterals }\end{array}$ & $\begin{array}{l}\text { IEA, ASEAN Plus Three, ECT, BRICS, } \\
\text { OECD, ASEAN Council on Petroleum }\end{array}$ & G20, IEA, OECD, IEP \\
\hline GEG reform & $\begin{array}{l}\text { Development of ASEAN Plus Three oil } \\
\text { emergency sharing mechanisms }\end{array}$ & $\begin{array}{l}\text { IEA treaty reform on OECD membership } \\
\text { and voting shares }\end{array}$ \\
\hline
\end{tabular}


Table 3 Relevant actors and international experience in the strategic pathway of developing and adopting the TCFD framework

\begin{tabular}{|c|c|c|c|c|}
\hline & $\begin{array}{l}\text { TCFD: metric } \\
\text { determination }\end{array}$ & $\begin{array}{l}\text { TCFD: scenario } \\
\text { methodologies }\end{array}$ & $\begin{array}{l}\text { TCFD: adapting to } \\
\text { state-owned } \\
\text { enterprises (SOEs) }\end{array}$ & $\begin{array}{l}\text { TCFD building } \\
\text { momentum }\end{array}$ \\
\hline $\begin{array}{l}\text { International } \\
\text { experience }\end{array}$ & \multicolumn{4}{|c|}{$\begin{array}{l}\text { Financial Stability Forum: Enhancing Market and Institutional Resilience, Paris Agreement, } \\
\text { Montreal Protocol }\end{array}$} \\
\hline State actors & $\begin{array}{l}\text { G20 member states and } \\
\text { their finance ministries }\end{array}$ & $\begin{array}{l}\text { G20 member } \\
\text { states and their } \\
\text { finance ministries }\end{array}$ & $\begin{array}{l}\text { G20 member states } \\
\text { and respective } \\
\text { SOEs }\end{array}$ & $\begin{array}{l}\text { G20 member } \\
\text { states and their } \\
\text { finance ministries }\end{array}$ \\
\hline Non-state actors & $\begin{array}{l}\text { Exchange operators, } \\
\text { multinational energy and } \\
\text { extraction companies }\end{array}$ & $\begin{array}{l}\text { Multinationals } \\
\text { that maintain } \\
\text { energy scenarios }\end{array}$ & SOEs & $\begin{array}{l}\text { Energy and } \\
\text { extractive } \\
\text { industry } \\
\text { companies }\end{array}$ \\
\hline GEGs/multilaterals & WB, C40, FSB & $\begin{array}{l}\text { IEA, ETC, FSB, } \\
\text { UNFCCC, IPCC }\end{array}$ & FSB & $\begin{array}{l}\text { CEM, C40, G20, } \\
\text { FSB }\end{array}$ \\
\hline
\end{tabular}

Note $\mathrm{TCFD}=$ Task Force on Climate-related Financial Disclosures

Table 4 Relevant actors and international experience in the strategic pathway of rationalising public energy finance

\begin{tabular}{|c|c|c|c|c|}
\hline & $\begin{array}{l}\text { Renewed } \\
\text { G20 focus } \\
\text { on phasing } \\
\text { out fossil } \\
\text { fuel } \\
\text { subsidies }\end{array}$ & $\begin{array}{l}\text { Multilateral } \\
\text { coordination on } \\
\text { phasing down high } \\
\text { carbon FDI and } \\
\text { development } \\
\text { support }\end{array}$ & $\begin{array}{l}\text { International sharing on } \\
\text { establishing effective } \\
\text { carbon pricing }\end{array}$ & $\begin{array}{l}\text { International } \\
\text { cooperation on } \\
\text { minimising carbon } \\
\text { leakage }\end{array}$ \\
\hline $\begin{array}{l}\text { International } \\
\text { experience }\end{array}$ & $\begin{array}{l}\text { G20 } 2009 \\
\text { and process }\end{array}$ & $\begin{array}{l}\text { OECD MDB } \\
\text { reforms }\end{array}$ & $\begin{array}{l}\text { ETS-UK, EU, } \\
\text { Australia, Canada, } \\
\text { California, South } \\
\text { Korea, Brazil } \\
\text { Tax-Mexico, Japan, } \\
\text { South Africa }\end{array}$ & $\begin{array}{l}\text { Switzerland-EU, UK- } \\
\text { EU, California- } \\
\text { Quebec, Climate } \\
\text { Leadership Council } \\
\text { (BAMs) }\end{array}$ \\
\hline State actors & $\begin{array}{l}\text { G20 } \\
\text { member } \\
\text { states and } \\
\text { their finance } \\
\text { ministries }\end{array}$ & $\begin{array}{l}\text { NDRC, MOFCOM } \\
\text { or SASC }\end{array}$ & \multicolumn{2}{|c|}{$\begin{array}{l}\text { Common: MOFCOM, NDRC, National Energy } \\
\text { Commission }\end{array}$} \\
\hline Non-state actors & $\begin{array}{l}\text { IOCs and } \\
\text { extractives }\end{array}$ & SOEs & $\begin{array}{l}\text { Certifiers/verifiers } \\
\text { (PwC, KPMG); fossil } \\
\text { fuel companies, } \\
\text { industrial sectors and } \\
\text { utilities }\end{array}$ & $\begin{array}{l}\text { International } \\
\text { corporations that have } \\
\text { already adopted an } \\
\text { internal shadow } \\
\text { carbon price (e.g. } \\
\text { IOCs) }\end{array}$ \\
\hline GEGs/multilaterals & G20 & \multicolumn{3}{|c|}{$\begin{array}{l}\text { OECD, WB, AIIB, IFC, ADB, WTO, IETA Article 6, GGGI, UNFCCC, } \\
\text { CPLC and the Carbon Pricing Panel, IMF, VCS }\end{array}$} \\
\hline GEG reform & $\begin{array}{l}\text { Re-establish } \\
\text { G20 FF } \\
\text { subsidy } \\
\text { reform } \\
\text { programmes }\end{array}$ & $\begin{array}{l}\text { MDB investment } \\
\text { standards and } \\
\text { portfolios }\end{array}$ & $\begin{array}{l}\text { Dedicated G20 and/or } \\
\text { World Bank working } \\
\text { group; expanded } \\
\text { CPLC/Carbon Pricing } \\
\text { Panel membership }\end{array}$ & $\begin{array}{l}\text { WTO rules on border } \\
\text { adjustment measures, } \\
\text { expanded } \\
\text { CPLC/Carbon Pricing } \\
\text { Panel membership }\end{array}$ \\
\hline
\end{tabular}


Table 5 Relevant actors and international experience in the strategic pathway of regionally connected, coordinated and secure electricity markets enabling cross-border trade of electricity through interconnectors

\begin{tabular}{|c|c|c|c|}
\hline & $\begin{array}{l}\text { Regional planning } \\
\text { of interconnector } \\
\text { routes }\end{array}$ & $\begin{array}{l}\text { Regional alignment of national EMR } \\
\text { leading to coordination of CDB }\end{array}$ & $\begin{array}{l}\text { Cooperation on } \\
\text { internationally } \\
\text { coordinated grid } \\
\text { cybersecurity }\end{array}$ \\
\hline $\begin{array}{l}\text { International } \\
\text { experience }\end{array}$ & $\begin{array}{l}\text { EU } \\
\text { interconnection, } \\
\text { US interstate }\end{array}$ & $\begin{array}{l}\text { EU market integration, EU Capacity } \\
\text { Allocation and Congestion Management } \\
\text { regulations }\end{array}$ & $\begin{array}{l}\text { Ukrainian power grid } \\
\text { cyber attack } \\
\text { DoE: Cybersecurity for } \\
\text { Critical Energy } \\
\text { Infrastructure }\end{array}$ \\
\hline \multirow[t]{2}{*}{ State actors } & \multicolumn{3}{|c|}{$\begin{array}{l}\text { State Grid Corporation of China, China Southern Power Grid, NDRC, } \\
\text { National Energy Administration }\end{array}$} \\
\hline & $\begin{array}{l}\text { MOFCOM, } \\
\text { NDRC }\end{array}$ & \multicolumn{2}{|l|}{ Power sector regulators (NEC) } \\
\hline Non-state actors & Siemens, GE & DNO; utilities, generator operators & $\begin{array}{l}\text { Symantec, Honeywell, } \\
\text { Verizon }\end{array}$ \\
\hline GEGs/multilaterals & $\begin{array}{l}\text { WTO, ECT, } \\
\text { MIGA, ICSID, } \\
\text { IFC, BIT }\end{array}$ & $\begin{array}{l}\text { IEA, ECT, IRENA, IEF, GIZ, CEM, } \\
\text { 21st Century Power Partnership, ISGAN }\end{array}$ & IEA, IMPACT, ITU \\
\hline GEG reform & \multicolumn{2}{|c|}{ Regional assistance from exiting GEGs to China and Asia } & $\begin{array}{l}\text { Reform of IEA to create } \\
\text { initiative on } \\
\text { cybersecurity? }\end{array}$ \\
\hline
\end{tabular}

Table 6 Relevant actors and international experience in the strategic pathway of international cooperation to accelerate smart management of EV electricity demand and deployment of cost-effective electricity storage

\begin{tabular}{|c|c|c|}
\hline & $\begin{array}{l}\text { Internationally standardised smart EV } \\
\text { charging stations }\end{array}$ & $\begin{array}{l}\text { International alignment of electricity storage } \\
\text { investment towards lithium-ion batteries }\end{array}$ \\
\hline $\begin{array}{l}\text { International } \\
\text { experience }\end{array}$ & $\begin{array}{l}\text { Dutch charging service providers: Open } \\
\text { Smart Charge Protocol (OSCP), GreenFlux } \\
\text { and Enerxis }\end{array}$ & $\begin{array}{l}\text { Tesla deployment in California, UK govt. } \\
\text { investment in battery deployment, MDB } \\
\text { reforms }\end{array}$ \\
\hline State actors & \multicolumn{2}{|c|}{$\begin{array}{l}\text { State Grid Corporation of China, China Southern Power Grid, NDRC, Standardization } \\
\text { Administration of the PRC }\end{array}$} \\
\hline Non-state actors & DNO, EV manufacturers & $\begin{array}{l}\text { Battery and EV manufacturers (BYD, } \\
\text { CATL), DNO }\end{array}$ \\
\hline GEGs/multilaterals & IRENA, IEA, IEC, IOS, IEEE & $\begin{array}{l}\text { World Bank, AIIB, ADB, MIGA, ICSID, } \\
\text { IFC, CCCMC, CEM, Mission Innovation, } \\
\text { GGGI, CIF, IFC, BIT }\end{array}$ \\
\hline GEG reform & $\begin{array}{l}\text { Current international standard setting } \\
\text { effective, widespread international } \\
\text { engagement and adoption required }\end{array}$ & $\begin{array}{l}\text { Coordinated reform and alignment of } \\
\text { investment standards and strategies of } \\
\text { MDBs }\end{array}$ \\
\hline
\end{tabular}




\section{Annex A.3: The Development of Emergency Response Measures for Oil}

The 1967 and 1973 oil crises raised the spectre of potentially large long-term politically induced supply disruptions. As the political situation in the Middle East became more fragile there was growing awareness and concern about the implications of the various choke points involved in the international oil trade, such as the Strait of Hormuz and Bab el Mandab between the Horn of Arica and Yemen.

In this context there was a growing view that security of supply would best be served by coordinated responses revolving around increased storage. The first response came from an initiative launched by Henry Kissinger as US Secretary of State and involved the creation of the International Energy Agency (IEA) in November 1974. Central to this was the IEA's Emergency Sharing Mechanism. This required the members, who were basically members of the OECD (France initially excluded itself but later joined), to maintain 90 days of oil consumption (crude and products) in storage. A series of rules were then laid down to govern the terms under which the stocks would be released. The European Commission, feeling rather outdone by the IEA, which was an American initiative, then introduced its own emergency scheme along similar lines, although the relationship between the two schemes was never clarified. In 1978, the USA began its Strategic Petroleum Reserve (SPR) that involved building very large crude storage capacity in salt caverns in Louisiana. The creation of the SPR led to much discussion about the role of freeriding on storage, since any release of stocks by the SPR would dampen price spikes internationally in what was a global market. More recently other countries, notably China, have been building up their strategic reserves, helped by the oil price collapse since June 2014.

In the 1980s, further supply security measures were effectively introduced as the result of the development of paper and futures markets. These initially emerged as informal forward markets but developed into formal markets in the late
1980s-New York Mercantile Exchange (NYMEX) and the International Petroleum Exchange (IPE), which later became the Intercontinental Exchange (ICE) in London. This allowed consumers (and producers) to hedge against price volatility.

These mechanisms were tested on only a few occasions. The first was the loss of crude supplies associated with the Iranian Revolution in the late 1970s and the Iran-Iraq war in the 1980s. This was not a real test because the SPR, while having been filled, had not yet built physical pumping capacity to recover the crude. In a very disrupted market where the IEA decided not to invoke the Emergency Sharing Mechanism, the result was everyone for themselves with very intense competition between US and Japanese companies. The result was effectively the second oil price shock. The next event was the loss of Iraqi and Kuwaiti crude supplies following Iraq's invasion of Kuwait in 1990. The price effects of this were initially dampened because Saudi Arabia was carrying significant spare capacity that it pushed into the market. At the start of the campaign to liberate Kuwait in 1991, the IEA released stocks, but all this did was to aggravate price volatility. In 2005, the IEA again announced a stock release in response to Hurricane Katrina and its impact on oil logistics in the Gulf of Mexico. There were few takers of the crude on offer.

There is a lively debate in the academic literature on the effectiveness of such mechanisms and their optimal design. However, the consensus among industry insiders is that in the event of a really serious disruption-for example closing the Strait of Hormuz - the IEA's scheme would fall to pieces as governments looked to their own national interests.

\section{Annex A.4: The International Renewable Energy Agency (IRENA)}

IRENA was established as an intergovernmental organisation in 2009, in order to increase the uptake of renewable energy worldwide. Having recognised that existing energy institutions put 
renewable energy at a disadvantage compared to other energy sources, the German government led a coalition of the willing in designing IRENA's mission. Its focus is on being a global voice and knowledge source for renewables (including renewable technologies and patents), providing policy advice on renewables and serving as a network hub for member states. It is open to all UN members, lending it a high degree of legitimacy, and all members have equal weight in the decision-making process. Given its soft mandate and focus on information, stakeholder engagement and agency are relatively high, with member states generally sending officials from their energy rather than climate or environment ministries to IRENA council meetings.

Nonetheless, there was initial resistance to the creation of IRENA. Reasons for abstaining varied, from reservations about renewables and fears of action against fossil fuel and nuclear interests, to scepticism about the creation of a new international organisation (given inefficiencies and deadlock in existing ones) and the financial burden imposed on member states. Several IEA member states, including France, the UK, USA, Canada, Italy, Japan and Australia did not want to create a rival to the IEA. Some emerging economies raised sovereignty concerns: Brazil was concerned that IRENA would try to limit its use of biofuels and large hydropower, for instance. While it took many years to gain political traction, most of the original abstainers ultimately joined. Membership now stands at 75 countries, including China, and 26 of 28 IEA member states.

Many of these stakeholders are unlikely supporters at first glance. This includes the United Arab Emirates (UAE) and Nigeria, both OPEC countries. The UAE has taken a significant role in funding several IRENA initiatives and largely kept the organisation afloat in its initial phases with the support of Germany. The decision to locate the headquarters in Abu Dhabi sent a strong political message about IRENA and renewables in that even oil exporting countries recognise their economic potential and are willing to contribute to IRENA. This message has become stronger following the collapse in oil prices in recent years, which has forced exporters to reconsider the role of fossil fuels in supporting economic growth and in turn, political stability.

\section{Annex A.5: The G20's Growing Role in Global Energy Cooperation}

The G20 is the most prominent of several global governance initiatives adopting a coalition of the willing approach. The global financial crisis in 2008 gave it new impetus and prompted it to broaden its scope from economic cooperation to energy and climate change. Like shifts in energy governance before it, this expansion was partly driven by exposure to high prices and volatility in oil markets; removing distortions and inefficiencies in energy markets was identified as a key line of defence. Moreover, at a time when non-OECD oil demand was about to overtake that of the OECD, and the representativeness and agency of the IEA were increasingly questioned, the G20 offered a forum that included established and emerging powers, as well as accounting for more than $80 \%$ of total primary energy demand and at least $50 \%$ of global fossil fuel trade.

The commitment to phase out inefficient and wasteful consumption subsidies was made at the G20 Pittsburgh Summit in 2009. Designing a robust reporting, but politically acceptable, mechanism proved challenging, given that price reform remains primarily an area of national competency. Gaps in the conceptual framing of the commitment-from lack of consensus regarding what constitutes a subsidy to varying interpretations of terms like "inefficient", "wasteful consumption", "rational circumstances" and "market stability"-led to discrepancies in the reporting of existing subsidies and those required to be phased out. While some have questioned the effectiveness of the commitment for this reason, it has successfully 
placed the issue of subsidies on the international agenda and helped create the longer-term conditions for reform. When oil prices collapsed, many governments took advantage of the political space to reform consumption subsidies.

The G20's role in energy cooperation has grown since, with a commitment to improve the transparency of energy data made at the St Petersburg Summit in 2013, and adoption of the G20 energy principles at the Brisbane Summit in 2014. Perhaps most importantly, while emerging economies have struggled to effect fundamental reforms at the multilateral level, they have been able to make a growing contribution to energy dialogue via the G20; for instance, China's use of its presidency in 2016 to champion green finance. Moreover, the Hangzhou Consensus reaffirmed "the importance of energy collaboration towards a cleaner energy future and sustainable energy security with a view to fostering economic growth", drawing perhaps the clearest links yet between global economic and energy and climate governance.

\section{Annex A.6: Case Studies, Going it Alone Versus Cooperative Action}

\section{Case study 1: IEA}

Pooled economic and political capital is more powerful than a single country acting alone. In response to the 1973 oil crisis, the USA took unilateral and multilateral action simultaneously. Unilaterally, the USA banned oil exports, which helped to reduce and stabilise oil prices in the short term. At the same time the USA was a founding member of the IEA in 1974, central to which was the emergency response mechanism (ERM), a multilateral organisation and cooperative mechanism to enable the group of consumers to exert greater market power over oil producers. The unilateral response of the oil export ban was arguably a short-term measure designed to address an acute short-term problem. The establishment of the IEA and ERM took longer to structure and implement than the USA's unilateral export ban but has arguably been more effective in achieving the desired objective of stabilising prices.

Before the ban was lifted in 2015, many critics argued that lifting the ban would increase production, as producers would begin to sell to the global market. The Council on Foreign Relations estimated production would rise by 1.2 $\mathrm{mb} / \mathrm{d}$, translating into a $1 \%$ increase in US GDP. Disentangling the impact of decreasing global oil prices on the US oil industry after lifting the ban and how US producers would otherwise be impacted, is challenging. After lifting the ban at the end of 2015, year-on-year production declined by $0.5 \mathrm{mb} / \mathrm{d}$, but this could have been much greater if the unilateral approach hadn't been reversed.

These two distinct approaches exhibit simultaneous unilateral and multilateral responses to the same issue. Dichotomising between collaboration and going it alone is somewhat of a fallacy, as countries have used a mixture of approaches to achieve the same objective.

Reforming the IEA by making it more representative of production and consumption to enable the IEA to fully achieve its remit presents significant challenges. Principally, countries such as China and India would need to move from associates to full members. The joint political will to overcome these hurdles, doesn't appear to exist. This is mainly due to the IEA's archaic voting system. Simply put, voting shares are determined on the basis of the oil consumption data from 1973, leaving China and India with little voting influence. If updated to more recent oil consumption data, the existing memberships' voting influence would significantly diminish. Modifications to the IEA's formal treaty would require ratification by the IEA's member states at the domestic level, which would likely run into significant domestic political challenges. These hurdles could be overcome by mutual effort, if the pooled political will and determination existed within the current IEA membership. Indeed, a 
coalition between the associate members would enable greater aggregate political capital, which could be leveraged to bring about modifications to the IEA's voting system. This stalemate is the context in which the questions of new institutional creation or formalised partnerships have arisen.

\section{Case study 2: IRENA}

The literature is unclear on the process by which states form new international institutions. This is made more complex as institutional formation often runs in parallel to diverging from existing institutions. What is clear is that new organisations are difficult to establish, especially as new institutions sometimes perform overlapping functions with those in existence, leading to fragmentation. Further, new institutions have high start-up costs, which can be avoided by simply working within, and reforming, existing organisations.

The formation of IRENA in 2009 can help probe these questions. IRENA was instigated by Germany, Spain and Denmark to balance the IEA's support for fossil fuels and nuclear power, in favour of greater support for renewable technologies. By forming a coalition of the willing (or coalition of dissatisfied states), rather than a bland consensus, the Germany-led coalition gradually grew in membership to become IRENA. In a broad sense, states chose to join during the formation stage to influence the institutional structure and objectives. Many governments had specific and unique drivers: the Obama administration, for example, viewed IRENA as a timely way to demonstrate a different approach to carbon options from that of the Bush administration.

It is too early to determine if IRENA has the teeth to achieve its goals. However, its formation represents a relatively unique departure from the crisis catalyst that drove the formation of the UN and the Bretton Woods institutions, one which may be difficult to repeat. The formation of IRENA as an entity with its own governing structures differs to the formation of the
International Partnership for Energy Efficiency Cooperation (IPEEC). Formed around the same time as IRENA, the eventual nesting of IPEEC within the IEA again illustrates that the formation of IRENA is relatively unique. It could be that the costs associated with institutional reform of the IEA outweighed those of institutional creation, leading to the formation of IRENA as an entity within its own right.

\section{Case study 3: Carbon trading}

Unilateral action can play a catalytic role in the development of an international or multilateral response. This interplay between unilateral and multilateral responses is clearly demonstrated in the parallel systems of the UK and EU emissions trading systems (ETS). The UK was able to implement carbon trading faster by going it alone, or unilateral action, but then extended that knowledge and expertise to the collaborative and multilateral approach of the EU ETS. This catalytic effect can also be observed in the recent proposal by the Climate Leadership Council's carbon tax proposal, which included a proposed border adjustment tax:

\section{Border adjustments for the carbon content of both imports and exports would protect American competitiveness and punish freeriding by other nations, encouraging them to adopt carbon pricing of their own.}

The merits of this strategy are debatable. However, the intention is clear: by taking unilateral action a future interlinked carbon pricing system could develop, achieved in the first instance without multilateral cooperation. Such a unilateral decision by the USA would have farreaching implications on trade and hence on global energy governance.

While the border adjustment tax could, in theory, be implemented more swiftly, the downside would likely be a trade war. While the border adjustment tax is not technically an import tariff, it is unlikely to comply with WTO rules. Even if it did, other countries would likely start to impose similar border adjustment taxes to protect their exporting industries and hence a 
trade war would likely ensue, damaging domestic growth across nations. Hence a multilateral, more complex approach, would likely lead to a more optimal outcome. The multilateral response would likely involve the linking of carbon markets through international accounting rules for transferable carbon allowances or credits under Article 6 of the Paris Agreement, or through the Emissions Mitigation Mechanism (EMM). Establishing the EMM would require extensive negotiations and leadership from the big emitters, such as China. Negotiations would likely take considerable effort and time, longer than the unilateral proposal of a border adjustment tax.

\section{Case study 4: Oil spills}

Oil spills and the environmental damage caused by them is an international challenge, as oil tankers cross borders and sea lanes and navigate international waters. Oil spills are an example of where an international response is stimulated by a crisis or shock. In 1967, the UK took the controversial decision to set fire to the shipwrecked Torrey Canyon supertanker to prevent leaking oil from spreading. Although contained within the borders of the UK, the oil spill also contaminated $80 \mathrm{~km}$ of the French coastline; hence the domestic action of the UK had a unilateral dimension to it. This led to several international conventions, including the recognition of the right of coastal states to take unilateral measures "to prevent grave and imminent danger to their coastline from oil pollution". In this example, unilateral action catalysed multilateral agreements and standards, which in turn protected the rights of states to act unilaterally. In the 1970s, the USA unilaterally forced oil tankers entering US ports to comply with double-hull standards, catalysing the international adoption of the 1973 MARPOL Convention and 1978 Protocol on maritime pollution, which extended US standards internationally.

\section{Case study 5: Chlorofluorocarbons and the Montreal Protocol}

A multilateral response stimulated by the perceived threat of unilateral trade sanctions can be observed in the banning of chlorofluorocarbons (CFCs) to prevent the depletion of stratospheric ozone. As the hole in the ozone layer grew over Antarctica in the early 1970s, the public became concerned over increased skin cancer rates. By the mid-1970s it had become clear that CFCs were the cause. Between the mid-1970s and 1980 s, led by the USA, several countries took domestic action and imposed bans and reductions in the use of CFC-based aerosols. International negotiations had been underway for some time but came to a head in the mid-1980s.

A key motivation of Europe and Japan to reach an agreement was the fear that the USA would take unilateral action and impose trade sanctions, if talks failed. In 1987, the Montreal Protocol was signed, with a clear tapering schedule for the production and use of CFCs globally. It should be noted, that another key component on reaching an agreement was the availability of substitutes for CFCs, which limits the replicability of this approach in other areas, and in particular climate change.

Nevertheless, the Montreal Protocol is widely acknowledged as the world's most effective environmental treaty. $98 \%$ of the production and consumption of ozone-depleting substances (ODS) has now ended; and the ozone layer is projected to recover to its pre-Antarctic ozone hole state over the next 50 or so years, and to its pre-industrial state in about 500 years. At the same time, the Protocol has made a major contribution to slowing the rate of global warming: almost all ODS, including CFCs and hydrochlorofluorocarbons (HCFCs), are themselves powerful greenhouse gases, typically far more powerful even than hydrofluorocarbons (HFCs). 
Another breakthrough was reached in October 2016, when nearly 200 countries agreed to phase down global emissions of highly climatewarming HFCs. The deal amends the Montreal Protocol, and requires cuts in HFC use starting in 2019 for wealthier countries, with all other nations significantly reigning in consumption by the end of the 2040s. The move could prevent up to $0.5^{\circ} \mathrm{C}$ in global warming above pre-industrial levels by the end of the century.

Much of the success of the Montreal Protocol has been attributed to its institutional design. The supreme decision-making body of the ozone regime is the Meeting of the Parties (MOP), with preparatory discussions taking place in the Openended Working Group (OEWG). These bodies have proved, in contrast to those in many other multilateral environmental agreements (MEAs), generally harmonious forums for resolving the key political, technical and financial issues faced by the parties. A sense of community has traditionally prevailed, which has been helpful in resolving disputes (although unfortunately, as discussed below, this positive atmosphere has not extended to discussions on HFCs, which have been comparatively acrimonious).

Nearly 30 years after its inception, the ozone regime has now reached a mature stage, where its institutions are well established and its main objective - the phase-out of the production and consumption of ODS - has been largely met. The Montreal Protocol, however, is still faced with several challenges, and not just that of rising HFC use: illegal trade in ODS, and the disposal of banks of stored ODS, for example, remain important concerns. Nonetheless, it is true to say that the Montreal Protocol is widely accepted as a highly effective regime. The result of this, however, is that the issue of ozone protection has largely dropped down the international agenda, receiving only limited political attention. ${ }^{5}$

\footnotetext{
${ }^{5}$ The text above draws heavily on a Chatham House Research Paper by Stephen O. Andersen, Duncan Brack and Joanna Depledge (2014).
}

\section{Annex A.7: The World Trade Organization and Energy Resources}

While the WTO, with its 164 member countries, provides the main global institutional framework for coordinating and governing international trade - trade in natural resources, including fossil fuels, falls largely outside its remit (though some rules have implications for resource reserves and related services). Separate chapters were included in the WTO texts to address issues related to agriculture and textiles, but not natural resources. Some regional agreements have tried to bridge this gap for energy, notably the Energy Charter Treaty and the energy chapter in the North American Free Trade Agreement (NAFTA), and there were efforts to address energy within the Transatlantic Trade and Investment Partnership negotiations.

Several reasons for the special treatment of natural resources in trade agreements have been cited. First, the geographical distribution of natural resources is highly uneven and location of production is largely immovable. Nearly $90 \%$ of oil reserves are located within just 15 countries. Second, the sovereign control of resourceendowed countries over their natural resources and their right to exploit them for economic and social development is recognised in international law (see UN General Assembly Resolution 1803 of 1962). Third, trade in natural resources is often perceived as a key national security issue by exporters and importers. Fourth, the extraction and consumption of resources produce severe negative externalities compared with most other traded products. Finally, a large proportion of resource trade takes place under long-term contracts, often through dedicated infrastructure such as pipelines or liquefied natural gas tankers. The exhaustibility of natural resources, and the potential for infringements on national security grounds, provide two potential justifications for trade restrictions under WTO rules, although these must be implemented in a nondiscriminatory way.

While these reasons may be broadly accepted, in practice there are often blurred lines or different interpretations between countries. Most 
importantly, the point at which a natural resource becomes a saleable commodity is often hard to distinguish and remains controversial. A further complexity is that while the General Agreement on Trade in Services (GATS) provisions do not include natural resources, a service relating to natural resources (exploration, exploitation, technical testing, transport) is subject to the GATS disciplines unless provided by government authorities. This had led to calls for a more coherent framework, specifying the rules that apply to each resource type, the qualifications needed for a resource to be considered a good or a service, and important issues for oil and gas, such as investment protection.

Another key issue is that while supply security concerns in consumer countries focus on the ability to import goods, the WTO is focused on avoiding import restrictions. Article XI of the General Agreement on Tariffs and Trade (GATT) 1994 requires that exports should not be subject to quantitative restrictions "other than duties, taxes or other charges", but it does not fix a maximum level for border taxes, except for those countries which accepted them within their accession agreements (including China). Article XI has been interpreted as not prohibiting export taxes, which explains why "more than a third of notified export restrictions are in resource sectors, where export taxes on natural resources appear to be twice as likely as export taxes in other sectors". In recent years, several key raw material suppliers have used export controls. Indonesia has introduced a ban on exports of unprocessed ores. Vietnam has also imposed restrictions on iron ore and copper, and export taxes have recently been debated in Brazil and India. In 2012, the USA, EU and Japan lodged complaints with the WTO over Chinese export quotas of rare earth minerals, and the quota system was withdrawn in late 2014. There have been various proposals for voluntary avoidance of export restrictions in times of crisis or extreme price volatility, which such restrictions tend to exacerbate.
Although there has been growing concern over the functioning of resource markets, the much delayed Doha round is unlikely to introduce major changes to the treatment of extractive industries at the WTO, partly because a significant constituency within the WTO negotiations argue that "access to, and use of, natural resources as well as the right to regulate, should remain outside the scope of negotiations". Past negotiations and instruments, such as the Generalized System of Preferences (GSP), concerning natural resources in GATT and WTO, were dominated by concerns about developing country dependency on raw material exports and structural inequalities in the international economic system as a potential cause (dependency theory). Discussions during the resource boom reflected concerns around high resource prices, extreme price volatility, increasing restrictions on trade and the diminishing ability of the WTO dispute settlement regime to solve resource trade disputes.

\section{Annex A.8: Nuclear Power: Decline or Resurgence?}

Nuclear power generation, as a share of global electricity supply, has decreased from a peak in 2006 , when it provided $15 \%$, to $10.8 \%$ in 2015 . Beyond public and political concerns over safety, financing and the economics of nuclear power have hampered deployment. Long construction times and high capital expenditure result in unfavourable risk-reward profiles, from the perspective of potential investors. Until 2013 the global average levelised cost of energy (LCOE) was \$93-94/MWh, but this jumped to $\$ 140 / \mathrm{MWh}$ in 2014. Estimates for the first half of 2015 put the high point valuation at $\$ 258 / \mathrm{MWh}$, rising to $\$ 290 / \mathrm{MWh}$ in the second half. This is the direct result of infrastructure costs increasing to $\$ 3.72-7.5 / \mathrm{MWh}$. Gas-fired generator build costs at the time were between \$0.46$1.65 / \mathrm{MWh}$. The near $50 \%$ increase in nuclear LCOE is due to underestimating the cost of 
building third-generation reactors. These thirdgeneration reactors are designed to be safer, with passive safety systems built into their design, rather than safety systems iteratively added to old designs. Due to design complications, delays and cost overruns the costs have risen.
As China gains experience in new nuclear deployment, initial capital costs will likely fall. If nuclear is to play an increasing role in power provision, international cooperation around technology sharing will be required, with China likely to play a leading role.
Open Access This chapter is licensed under the terms of the Creative Commons Attribution 4.0 International License (http://creativecommons.org/licenses/by/4.0/), which permits use, sharing, adaptation, distribution and reproduction in any medium or format, as long as you give appropriate credit to the original author(s) and the source, provide a link to the Creative Commons license and indicate if changes were made.
The images or other third party material in this chapter are included in the chapter's Creative Commons license, unless indicated otherwise in a credit line to the material. If material is not included in the chapter's Creative Commons license and your intended use is not permitted by statutory regulation or exceeds the permitted use, you will need to obtain permission directly from the copyright holder. 